OḶEGS KRASNOPJOROVS

\title{
WHY IS EDUCATION PERFORMANCE SO DIFFERENT ACROSS LATVIAN SCHOOLS?
}

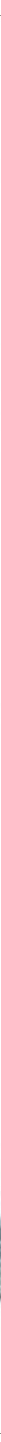




\section{CONTENTS}

SUMMARY 3

INTRODUCTION 4

1. DATA AND METHODOLOGY

2. ONE-FACTOR ANALYSIS 11

3. MULTIFACTOR ANALYSIS 16

3.1 Weighted least squares regression 16

3.2 Oaxaca-Ransom decomposition $\quad 22$

3.3 Stochastic Frontier Analysis $\quad 24$

CONCLUSIONS 27

$\begin{array}{ll}\text { APPENDIX } & 28\end{array}$

BIBLIOGRAPHY

CSB - Central Statistical Bureau of Latvia

EU - European Union

GDP - Gross Domestic Product

IT - Information Technology sector

LFS - Labour Force Survey

NCE - National Centre for Education

NUTS - Nomenclature of Territorial Units for Statistics

OECD - Organisation for Economic Co-operation and Development

PISA - Programme for International Student Assessment

SFA - Stochastic Frontier Analysis

vs - versus

USA - United States of America 


\section{SUMMARY}

This paper aims at identifying the school characteristics consistently associated with better performance of pupils on state exams. First, we find that exam scores are positively related to school size (the number of pupils in the respective school) and teacher salaries, but negatively - with teacher age. Meanwhile, quantitative inputs like the number of teachers and computers per pupil are not robust determinants of education performance. Second, we show that pupils in urban and rural schools would perform similarly if characteristics of these schools were the same. The OaxacaRansom decomposition fully explains the urban-rural exam score gap by a greater number of pupils and higher teacher salaries in urban schools as well as by different pupil structure; in turn, pupils' ethnic origin plays in favour of rural schools. Finally, Stochastic Frontier Analysis models show that school size is a robust efficiency determinant, while school location in the Riga region or in another big city is not. The bottom line is that structural reforms involving school mergers and a rise in teacher salaries might bring non-negligible dividends in terms of education quality.

Key words: education performance, school size, rural schools, Oaxaca-Ransom decomposition, Stochastic Frontier Analysis

JEL codes: I21, C1

The views expressed in this publication are those of its author Oḷegs Krasnopjorovs who is an employee of the Monetary Policy Department of Latvijas Banka. The author thanks Kārlis Būmanis (a graduate of Stockholm School of Economics in Riga) for the assistance provided in constructing the database as well as Mārtiņš Bitāns, Konstantīns Beṇkovskis, Gundars Dāvidsons and Kristaps Svīḳis (Latvijas Banka) for the comments and discussion. The author assumes responsibility for any errors and omissions. 


\section{INTRODUCTION}

The quality of Latvia's education system, including that of general secondary education, has been raising concerns for a long time. According to the recent public opinion survey Latvijas Barometrs, the quality of general secondary education in the country is evaluated with three points on a five-point scale. This rather modest result has remained broadly unchanged for years with the main problems identified being a shortage of good teachers, low teacher salaries, insufficient education quality and low pupil discipline (Latvijas Barometrs (2016)). OECD (2016) acknowledges that teacher salaries in Latvia are low and the remuneration scale - flat; these aspects hinder the attraction of young talent to the profession. The average score of state centralised exams (Grade 12) has not improved over the recent years (Information Agency LETA (2017)), building public confidence in the need for reform.

The results achieved are modest, although Latvia, compared to any other EU country, spends the largest share of its general budget on education. Public spending on education exceeds the EU average also in terms of percentage of GDP. The funding provided so far has been sufficient to maintain a wide school network. Several middle and secondary schools are attended by only a few dozen pupils; the unfavourable demographic situation has decreased the pupil-to-teacher ratio to the lowest level among the EU countries. However, the financial resources available have not been sufficient to implement substantial teacher salary increases which remain low both according to Latvian and international standards, and this translates into a low prestige of the profession. Scarcity of young employees makes Latvian school teachers one of the most senior ones in the EU. But until now, school merging that would free resources to substantially raise teacher salaries has been slow, it has often been challenged by municipalities and is rather unpopular with the general public.

The situation in various general education schools of Latvia is different, and many of them could be considered models of best practice. The exam scores demonstrated by the pupils belonging to the first decile of Latvian schools are on average two thirds higher than those shown by pupils from the last school decile. The best performing schools are of different types, they are located in various regions and their languages of instruction differ (see Tables A1 and A2). Therefore, simple inspection of data does not make it possible to assess whether there are any fundamental factors behind the considerable differences in school performance.

Yet little systematic research has been carried out to understand which school characteristics are consistently associated with better education achievements. The scope of academic literature employing Latvian school data is mainly limited to analysing the correlation coefficient and constructing one-factor regressions (e.g. Laizāne (2014); Purviņš (2017)).

Although exam scores are publicly available on the NCE website, this dataset has never been analysed simultaneously with various school characteristics, not even mentioning control variables. For instance, the urban-rural exam score gap has been well-known for years, but the reasons behind it are unclear. Do rural schools perform worse because of unfavourable school characteristics (if yes, due to which ones exactly?), unfavourable socio-economic situation in rural areas, different ethnic origin of pupils or some unobserved factors? To develop a successful economic policy in the field of general secondary education it is crucial to find out the fundamental factors allowing some Latvian schools to perform considerably better than others. 
The aim of our paper is to close loopholes of the previous studies and identify the school characteristics consistently associated with better education performance of pupils. To our best knowledge, this paper is the first systematic attempt to simultaneously apply several econometric techniques, such as the weighted least squares multifactor regression, Oaxaca-Ransom decomposition and Stochastic Frontier Analysis to Latvian school data.

Academic literature at global level has identified several school characteristics that might affect education performance of pupils. However, conclusions with regard to some characteristics remain ambiguous perhaps because of different national situations. Thus, the marginal products of the respective factors also differ.

For instance, the teacher-to-pupil ratio and the class size are more likely to have a positive impact on education outcomes in the countries with overcrowded schools and insufficient number of teachers (see a study on the Philippines by Abrigo et al. (2014)). Meanwhile, based on USA data, Carter (2012), Hoxby (1998), Chingos (2010), Rivkin et al. (2005), find that the impact of the teacher-to-pupil ratio or class size is insignificant.

Many papers emphasise that it is much more important to invest in teachers' quality rather than in their quantity (e.g. Escardíbul and Calero (2013)). Therefore, education performance of pupils is often linked with teacher qualification. Several papers have documented a positive link between teacher qualification and pupil education performance, particularly, in mathematics (Clotfelter et al. (2007), Harris and Sass (2008), Chingos and Peterson (2011). Some papers argue that knowledge of a particular subject by a teacher plays an even more important role in pupil education performance than teachers' formal education degree (Metzler and Wössmann (2010)). However, such data on Latvia are not available; therefore, this paper employs the formal education degree of teachers. The impact of teacher work experience and seniority was found to be positive by Pereira and Moreira (2007) in their study on Portugal and Scippacercola and D'Ambra (2014) on Italy, but negative by Carter (2012) in her study on the USA. Rivkin et al. (2005) as well as Staiger and Rockoff (2010) argue that the impact of work experience is present only during the first few years of professional life and vanishes afterwards.

Several research papers have found a positive and significant link between teacher salaries and pupil education performance (see, e.g. Loeb and Page (2000) on the USA, Dolton and Marcenaro-Gutiérrez (2011) as well as Barber and Mourshed (2007) on international evidence). Higher teacher salaries can improve the prestige of the profession, thus motivating the most capable young people to choose the teaching profession and start working in the education sector. Hanushek (2011) emphasises that it is crucial to attract young talent to the profession and have an opportunity to get rid of the pedagogues who do not measure up to the task. It should be noted that the best school systems typically do not allow bad teachers to stay in the teaching profession (see Kane et al. (2008) on the USA as well as Barber and Mourshed (2007) on international evidence).

There is a strong international evidence that private schools deliver, on average, better education outcomes than the public ones. This finding is present in Alexander et al. (2010) regarding New Zealand, Hirao (2012) concerning the USA, Pereira and Moreira (2007) in relation to Portugal and Crespo-Cebada et al. (2014) as regards Spain. 
There is also enough international evidence on the positive scale effect. The impact of school size on pupil performance was found positive, e.g. by Burney et al. (2013) for Kuwait, Huguenin (2015) for Switzerland, Essid et al. (2013) for Tunisia as well as Pereira and Moreira (2007) for Portugal.

Finally, several papers emphasise the role of school location, e.g. whether a school is located in an urban or rural area (Alexander et al. (2010)) or how many public schools there are in a municipality (Agasisti (2013)). Burney et al. (2013) believe that the impact of school location stems from different population characteristics in different regions of the country. The impact of socio-economic factors on education performance is also stressed by Raposo and Menezes (2011) in relation to Brazil, Yalçin and Tavşancil (2014) concerning Turkey and Huguenin (2015) with regard to Switzerland.

Several papers have found that the relationship between spending on education and academic achievements is far from perfect. An increase in funding alone offers no guarantee for improving education outcomes (Hanushek (1997), Hauner and Kyobe (2008)).

As for the variable reflecting education performance of pupils, researchers typically employ state exam scores or PISA test results provided that these data are available. This paper uses state exam scores due to their universal coverage (PISA tests are not held in all schools). We also incorporate all indicators that might affect education performance as identified by the literature and for which data on Latvia are available.

This paper is structured as follows. Section 1 briefly reviews the methodology of multifactor analysis techniques, including the weighted least squares regressions, Oaxaca-Ransom decomposition and Stochastic Frontier Analysis as well as discusses data. Section 2 examines how exam scores are associated with the key school characteristics and how schools with high exam scores differ from those with low exam scores. In Section 3 we present the main empirical results from the multifactor analysis, but the last Section concludes. 


\section{DATA AND METHODOLOGY}

We combine data from the publicly available dataset of state exam scores with various school characteristics provided by the Ministry of Education and Science and contained in publicly unavailable datasets. Moreover, we add the Ministry of Education and Science dataset containing data on teachers' salaries in public schools posted on the Re:Baltica website.

The dataset for the academic year 2014/2015 includes 699 education institutions. Almost all school characteristics were observed in September 2014, while exams took place in May-June 2015. The dataset was narrowed to exclude vocational, evening and extramural schools which typically have considerably lower exam scores. The resulting dataset consists of 652 general education institutions, 50 of which represent gymnasiums, 299 - secondary schools (up to Grade 12) and 303 - middle schools (up to Grade 9; see Table 1).

Table 1

Structure of general education institutions in Latvia (excluding vocational, evening and extramural schools; the academic year 2014/2015)

\begin{tabular}{|c|c|c|c|c|c|}
\hline & Total & $\begin{array}{r}\text { Except } \\
\text { gymnasiums }\end{array}$ & $\begin{array}{r}\text { Secondary } \\
\text { schools } \\
\end{array}$ & $\begin{array}{l}\text { Middle } \\
\text { schools }\end{array}$ & $\begin{array}{r}\text { Gymma- } \\
\text { siums }\end{array}$ \\
\hline Number of schools & 652 & 602 & 299 & 303 & 50 \\
\hline \multicolumn{6}{|l|}{ By ownership: } \\
\hline Public & 627 & 581 & 282 & 299 & 46 \\
\hline Private & 25 & 21 & 17 & 4 & 4 \\
\hline \multicolumn{6}{|c|}{ By language of instruction: } \\
\hline Latvian & 512 & 469 & 191 & 278 & 43 \\
\hline Russian & 88 & 83 & 72 & 11 & 5 \\
\hline Other & 52 & 50 & 36 & 14 & 2 \\
\hline \multicolumn{6}{|l|}{ By location: } \\
\hline Big city & 191 & 165 & 133 & 32 & 26 \\
\hline Small city & 117 & 95 & 70 & 25 & 22 \\
\hline Village & 344 & 342 & 96 & 246 & 2 \\
\hline
\end{tabular}

Source: Ministry of Education and Science data.

When completing Grade 12, pupils have to take three compulsory state centralised exams, i.e. Latvian, mathematics and a foreign language (a vast majority of pupils take an English exam). Furthermore, to examine performance of middle schools as well, we employ Grade 9 exams for the same three subjects. We did not include elective subjects since only part of pupils choose them as exam subjects, and this selection might depend on pupil abilities.

The conclusions of this paper are drawn from both one-factor and multifactor analyses. The one-factor analysis consists of pairwise associations between the exam scores and key school characteristics; these school characteristics differ substantially among schools delivering higher and lower state centralised exam results. Meanwhile, the multifactor analysis consists of the multifactor weighted least squares regressions, Oaxaca-Ransom decomposition and Stochastic Frontier Analysis.

We began by checking whether school characteristics significantly differ between schools with higher and lower pupil achievements on state centralised exams. The 
comparison was made for the entire dataset, excluding state gymnasiums and gymnasiums, as well as within the subsets of secondary schools and middle schools. Six most important school characteristics were considered, i.e. the number of pupils in a school, average salary per teacher (both per capita and for full-time work), the average age of teachers, share of teachers holding a master's degree, number of teachers and computers per pupil.

The impact of different factors on exam scores was assessed simultaneously with the following regression model:

$y_{i}=b_{0}+b_{1} X_{i}+b_{2} Z_{i}+\varepsilon_{i}$

where $\mathrm{y}$ is the average exam score of pupils in school $\mathrm{i}, \mathrm{X}$ represents a vector of school characteristics, $\mathrm{Z}$ is a vector of control variables and $\varepsilon$ is an error term.

It should be noted that $y$ is an index reflecting the recalculated exam scores in three compulsory subjects, i.e. English, mathematics and Latvian in two Grades (9 and 12). Raw exam scores in each subject range between 0 and 100. Exam scores in Grade 9 are typically higher than those in Grade 12, thus simple averaging of raw exam scores would bias the dependent variable in favour of middle schools. Likewise, the average English exam score is higher than that of mathematics exam. Therefore, we normalise exam scores in each of the six categories (subject/grade) to the country average performance and then calculate the average of these normalised exam scores.

The number of pupils in a school was used as an observation weight. Exam scores in the small schools with just a few pupils taking an exam can be significantly influenced by outliers or unobservable factors rather than the main school characteristics employed in this study. To minimise this issue, the big schools are given a larger weight than the small ones. Furthermore, the number of pupils (in logs) was included as one of the factors potentially affecting education performance; the inclusion of this factor was justified by the possible scale effect.

Vector X also includes the key inputs of the study process. The number of teachers and computers per pupil were the quantitative inputs employed in this study. Meanwhile, the qualitative variables of inputs included various teacher characteristics, such as the formal education degree, teacher age and salary (the latter might proxy unobservable teacher characteristics, e.g. motivation or teaching quality).

The formal education degree was proxied by the share of teachers holding a master's degree. The data on the average teacher net monthly salary in euro (in January 2015) come from the Re:Baltica website, and they are available on public schools (627 out of 652 schools are public). The average age of teachers in a school was calculated by using teacher breakdown by age provided by the Ministry of Education and Science for each school at 5-year intervals. It should be noted that the age of teachers teaching a particular subject is not observable. However, the average age of teachers in a school might even be a more appropriate factor of education performance if the particular subject is taught by different teachers in different grades.

To minimise the omitted variable bias, we also include control variables Z. First, girls usually perform better in exams, but repeaters - worse. Therefore, we included the share of girls and the share of repeaters in Grades 9 and 12 as control factors. Second, we differentiate schools according to the language of instruction into three groups, i.e. 
Latvian, Russian or other (the latter includes other ethnic minority schools as well as mixed schools in which only pupils of some classes are instructed in Latvian only). It should be noted that Latvian is a widely used language of instruction in all three groups of schools; however, school differentiation by the language of instruction might reflect the ethnic background of the majority of pupils and teachers. Third, we include dummies with regard to the location of a school, i.e. in a big city, small city or village. We regard nine cities of republican importance as big ones; the smallest city in this group is Jēkabpils with 23 thousand inhabitants. Fourth, to control the likely impact of socio-economic factors on pupil performance ${ }^{1}$ we include the registered unemployment rate in the municipality ${ }^{2}\left(\%\right.$; in February $2015^{3}$ ) and the average net wage in the municipality (euro; 2014) ${ }^{4}$. These data were extracted from the databases of the State Employment Agency and CSB respectively.

As a next step, we employ the Oaxaca-Ransom decomposition to examine whether any factors can explain the difference in exam scores between different types of schools, i.e. urban schools vs the rural ones, schools located in the capital city region vs those located in other regions as well as secondary schools vs middle schools. Originally proposed to study gender wage gaps, the Oaxaca-Ransom decomposition can be applied to explain the differences in any continuous outcome across any two groups. Some studies have already employed this method in assessing education performance (e.g. Barrera-Osorio et al. (2011)). The Oaxaca-Ransom decomposition splits the observed exam score gap into two components: one attributable to the differences in the observed school characteristics (the endowment effect) and the other one - to the unexplained part.

Particularly, the difference between the average exam scores in urban schools $\bar{Y}_{A}$ and rural schools $\bar{Y}_{B}$ can be expressed as a function of determining factors $\bar{X}_{A J}$ and $\bar{X}_{\beta J}$ :

$\bar{Y}_{A}-\bar{Y}_{B}=\bar{X}_{A J} \beta_{A J}-\bar{X}_{\beta J} \beta_{B J}$

where $\beta_{A J}$ and $\beta_{B J}$ are the regression coefficients obtained from regressions in the subsets of urban and rural schools respectively. Splitting equation (2) into two parts yields:

$\bar{Y}_{A}-\bar{Y}_{B}=\bar{X}_{A J}\left(\beta_{A J}-\beta_{B J}\right)+\beta_{A J}\left(\bar{X}_{A J}-\bar{X}_{B J}\right)$

where $\beta_{A J}\left(\bar{X}_{A J}-\bar{X}_{B J}\right)$ is part of the exam score gap explained by differences in school characteristics and $\bar{X}_{A J}\left(\beta_{A J}-\beta_{B J}\right)$ is the unexplained part, which basically shows the exam score gap that would be present if urban and rural schools shared the same observable characteristics.

\footnotetext{
${ }^{1}$ Ideally, one should control the family background of each pupil, but the respective indicators are not observable.

2 There are 119 municipalities in Latvia. The actual unemployment rate derived from the LFS would have been preferable, but this indicator is observable only in the breakdown of six NUTS 3 regions.

${ }^{3}$ The selection of a specific month has no significant effect on results as the unemployment rate is changing slowly. February was chosen as a month before seasonal workers are typically hired.

${ }^{4}$ Excluding private sector firms with less than 50 employees, as data on these firms are not available.
} 
The assumption regarding the choice of reference exam score equation affects both the estimates and interpretation of results. If one chooses to use the rural school equation as a reference, the unexplained exam score part is interpreted as premium of urban schools. Meanwhile, the selection of the urban school equation as a reference changes the interpretation of the unexplained part to penalty of rural schools. In order to avoid these extreme assumptions, Oaxaca and Ransom (1994) advise to use a pooled (all schools) equation as a reference (with the respective regression coefficients $\beta_{C j}$ ), thus splitting the exam score gap into three parts:

$\bar{Y}_{A}-\bar{Y}_{B}=\bar{X}_{B J}\left(\beta_{C J}-\beta_{B J}\right)+\bar{X}_{A J}\left(\beta_{A J}-\beta_{C J}\right)+\beta_{C J}\left(\bar{X}_{A J}-\bar{X}_{B J}\right)$

where the gap in exam scores is divided into differences in the observed school characteristics $\beta_{C J}\left(\bar{X}_{A J}-\bar{X}_{B J}\right)$ and the unexplained part which consists of penalty on rural school weakness $\bar{X}_{B J}\left(\beta_{C J}-\beta_{B J}\right)$ and urban school strength $\bar{X}_{A J}\left(\beta_{A J}-\beta_{C J}\right)$. In this paper, we employ the Oaxaca-Ransom methodology and report the unexplained part as an aggregation of strength and weakness. It should be noted, however, that the unexplained part may also reflect the differences in the unobserved factors that might be significant determinants of exam scores (e.g. variations in parental education or income level between schools within a municipality).

Researchers may choose whether to include a rural location dummy into the pooled regression. We use the Neumark (1988) approach as a base specification and do not include dummies according to which a school sample is divided into two groups in the regression equation. However, we also report the results of alternative specification in which the respective dummy is included in the regression equation. Our results are robust subject to this choice.

Finally, we implement the SFA technique to study which factors determine school efficiency, i.e. allow schools to achieve higher state exam scores with the same bundle of inputs. This parametric method originally proposed by Aigner et al. (1977) was widely applied to study efficiency determinants both at microeconomic and macroeconomic levels. This method is also widely used to study school efficiency determinants (see, e.g. Pereira and Moreira (2007) as well as Scippacercola and D'Ambra (2014)). Compared to the non-parametric Data Envelopment Analysis method, the SFA is immune to outliers and is more feasible in the case of several input variables.

We follow Coelli (1996) and Belotti et al. (2013) to estimate both the relation between output and inputs, and inefficiency determinants via one-step approach, using the following output-oriented equation system:

$$
\left\{\begin{array}{l}
y_{i}=b_{0}+b_{1} X_{i}+\left(V_{i}-U_{i}\right) \\
U_{i}=c_{0}+c_{1} F_{i}+\varepsilon_{i}
\end{array}\right.
$$

where $\mathrm{X}$ is a vector of inputs, $\mathrm{V}$ denotes a random error, $\mathrm{U}$ is non-negative technical inefficiency, $\mathrm{F}$ - a vector of inefficiency determinants.

The basic idea is that schools use labour and physical capital as inputs to provide output - education services of good quality (proxied as exam scores in the paper) to the public. The objective function of a school is to maximise the average exam score 
while keeping its inputs unchanged. Best practice examples are identified and then linked by the stochastic frontier. It is assumed that the schools lying on the frontier are fully efficient. The stochastic frontier reflects the highest exam score that can be achieved with the respective bundle of inputs. Meanwhile, the absolute majority of schools exhibit considerable inefficiency, lagging behind the stochastic frontier (see Chart 1).

Chart 1

Best practice stochastic frontier and school inefficiency

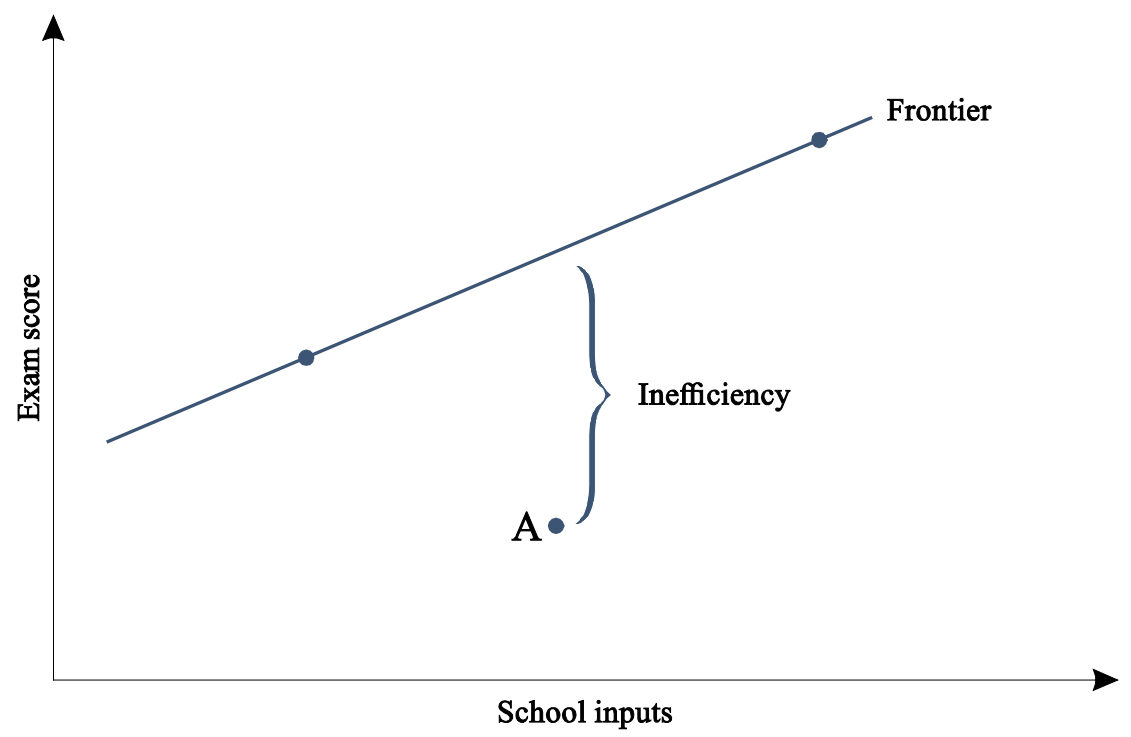

Source: Created by the author.

This output-oriented inefficiency may be expressed as a vertical distance between school observation and the stochastic frontier; it may be correlated with factors other than inputs and output. The basic specification of this paper includes school size and location dummies as potential efficiency determinants. For a robustness check, we used different bundles of inputs and efficiency determinants; the results are robust subject to this choice.

Several methodologies employed in this paper in addition to the regression approach can be regarded as a robustness check. Thus, the relationship between the respective factor and education performance can be considered robust if the relationship exists irrespective of the methodology chosen.

\section{ONE-FACTOR ANALYSIS}

We begin with establishing univariate associations between the key school characteristics and average exam scores. Then we check whether the key school characteristics vary considerably between schools with higher and lower exam scores.

The first view of the distribution of exam scores among schools suggests that it is close to the normal one (see Chart A1). It should be noted that state gymnasiums score significantly higher in exams, followed by gymnasiums, secondary schools and middle schools (see Chart A2). Private schools, on average, tend to overperform public schools which is consistent with the literature on other countries; however, private schools also have larger variation of average exam scores (see Chart A3). 
Pupil education performance in schools located in big cities is significantly higher than in rural schools (see Chart A4). Many schools in Riga and Pieriga have relatively high exam scores. By contrast, Latgale (the region with the highest unemployment rate and lowest average wage) and Vidzeme (the region with a relatively large share of rural population) have several underperforming schools (see Chart A5).

The average exam scores in schools with the Latvian language of instruction are significantly higher than those of ethnic minority schools, particularly in Grade 12 (see Chart A6). However, this difference is to a large extent driven by a lower score in the Latvian language exam in ethnic minority schools (see Chart A7). What is more intriguing, schools with the Latvian language of instruction score significantly higher in English exam (see Chart A8); by contrast, schools with the Russian language of instruction, compared to those with the Latvian language of instruction and other ethnic minority schools, achieve significantly higher exam scores in mathematics (see Chart A9).

The exam score variation in Grade 12 is higher than in Grade 9 not only in the right part of the distribution (possibly, as a result of exam scores in gymnasiums), but also in its left part (see Chart A10). This is in part due to the uniform Latvian exam in Grade 12 (therefore, ethnic minority schools obtain lower scores than those with the Latvian language of instruction), but in Grade 9 it differs between schools with the Latvian language of instruction and those of other languages of instruction. It should be noted that exam scores in Grade 9 are typically higher than in Grade 12. In both cases, however, the average state exam score is higher in English but lower in mathematics (see Charts A11 and A12).

Schools with more pupils tend to have higher average exam scores (Charts 2 and A13). A typical school in Latvia has only a few hundred pupils, while only several schools have more than a 1000 pupils (see Chart A14). It should be noted that middle schools tend to be considerably smaller than other school types (see Chart A15). About 80\% of middle schools are located in rural areas, while more than two thirds of secondary schools - in cities. State gymnasiums and gymnasiums are also mainly located in cities (see Table 1).

Teachers' average gross monthly salary for full-time work in public schools is about 540 euro, which is only about $70 \%$ of the average salary in the economy (see Chart A16). It should be noted that employees of the education sector (most of them are school teachers) have more years of schooling than employees in the economy on average (16.9 and 15.6 years respectively in $2014^{5}$ ). This 1.3-year difference suggests that the wage premium should be about 10\% (see Vilerts et al. (2015)). OECD (2016) notes that the average salary of a middle school teacher, who has been in service for 15 years, amounts to 52\% of GDP per capita in Latvia (adjusted for purchasing power parity), while this indicator is at least twice as large in several OECD countries. It should be noted, however, that teachers work more than full time on average (1.2 fulltime equivalent per teacher in January 2015; see Chart A17). Kurtosis of full-time salary distribution is significantly larger than salary distribution per employee. This makes workload differences an important driver of teachers' income gaps.

${ }^{5}$ Author's calculations based on Latvian LFS micro data. 
Chart 2

Association between the number of pupils in a school and exam score

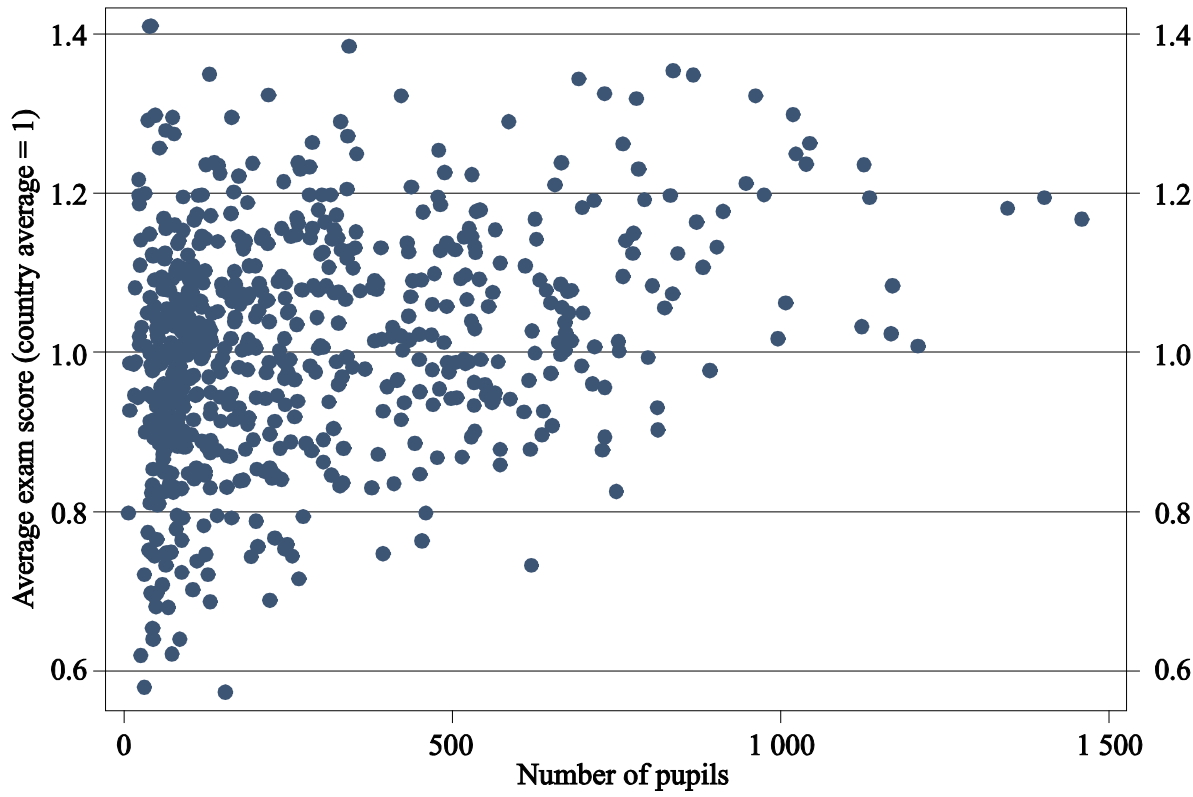

Sources: Ministry of Education and Science data and the author's calculations.

There is a positive association between the average teacher salary in a school and average exam score in the particular school, whenever a teacher salary is expressed per employee or per full-time equivalent (see Charts 3 and A18). Teachers of larger schools receive higher salaries; the workload is also usually higher in such schools (see Charts A19-A21). Typically, the average teacher salary in state gymnasiums is 1.5 times higher than in middle schools, while salaries of gymnasium and secondary school teachers lie mainly in between these two extremes (see Chart A22); this difference is partly determined by the fact that the workload in most middle schools is lower than in other schools. As rural schools are predominantly middle schools with a rather small number of pupils, teachers of these schools cannot earn as much as their colleagues in urban schools (see Chart A23). Teachers employed by schools with the Russian language of instruction usually receive higher salaries since these schools are mainly located in big cities and have a relatively large number of pupils (see Chart A24).

There is a negative association between the average age of teachers in a school and exam scores (see Chart 4). This negative association is particularly strong among the big schools (see Chart A25). Eurostat data reveal that Latvia has one of the most senior teachers among the EU countries. The average age of a school teacher calculated on the basis of the Ministry of Education and Science data is about 47 years (see Chart A26). This is close to the average age of an education sector employee calculated by using Latvian LFS micro data. It suggests that employees of the education sector are older than those working in other economic sectors. An education sector employee is, on average, almost five years older than an average employee in the economy (see Chart A27). Low salaries and low prestige of the profession impede inflow of young talent into the sector. The share of employees below 40 in the education sector is the lowest among all economic sectors (see Chart A28). 
Chart 3

Association between teacher salary for full-time work and exam score

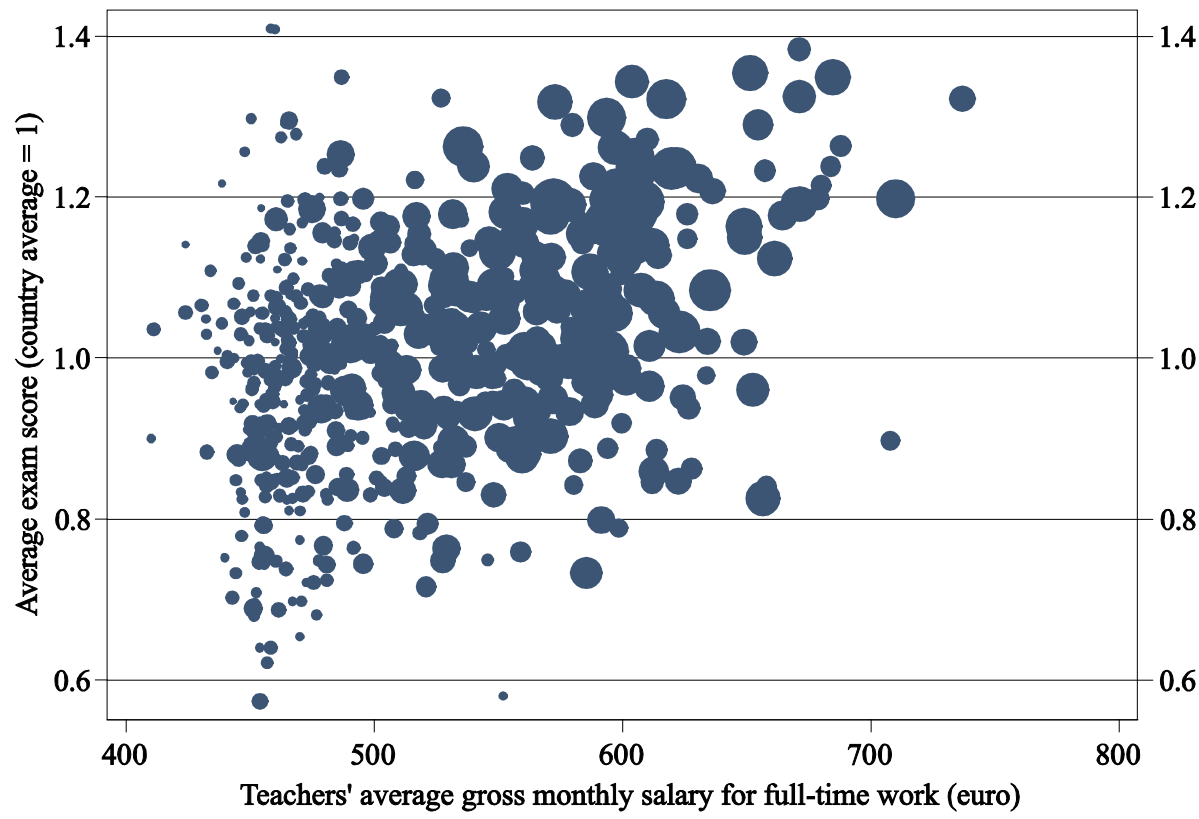

Sources: Ministry of Education and Science data and the author's calculations.

Notes. The diameter of each circle reflects the number of pupils in the respective school. Riga State Gymnasium No. 1 is not included due to its atypical value.

Chart 4

Association between teacher age and exam score

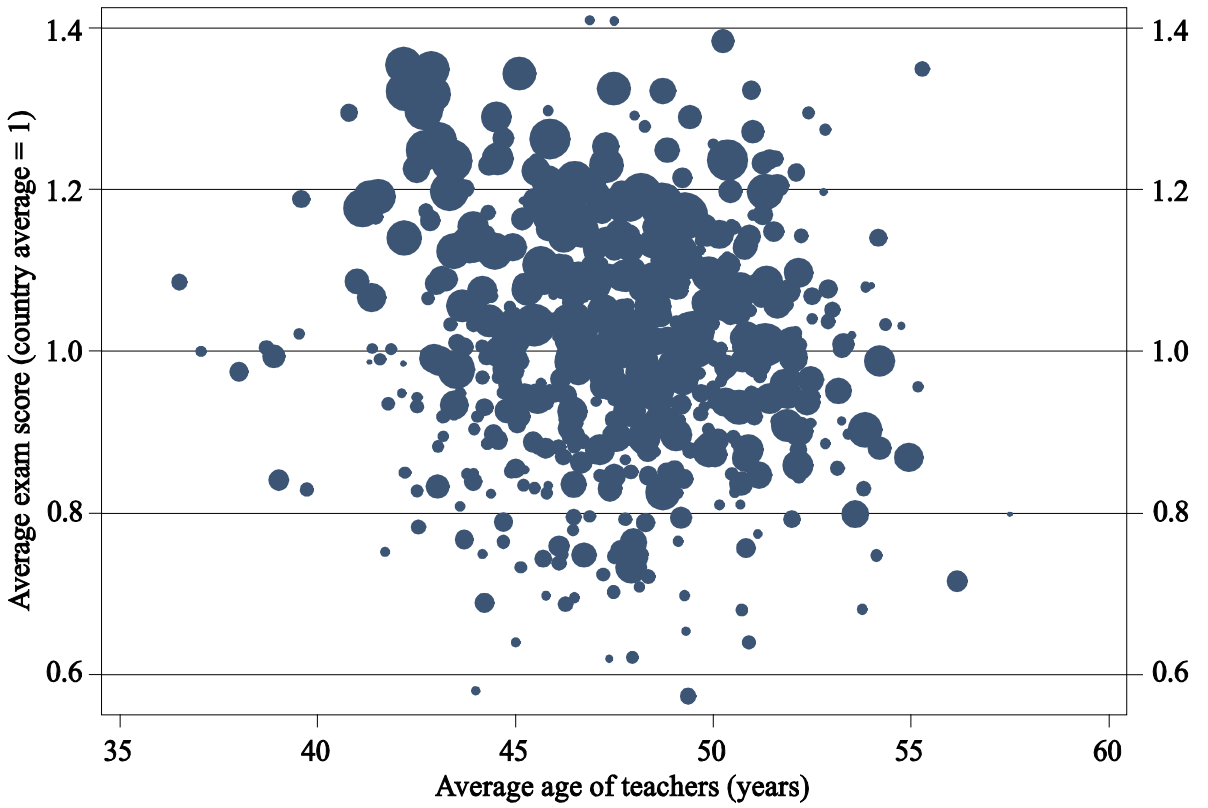

Sources: Ministry of Education and Science data and the author's calculations.

Notes. The diameter of each circle reflects the number of pupils in the respective school. Riga State Gymnasium No. 1 is not included due to its atypical value.

The average age of teachers does not differ substantially with respect to the number of pupils in a school (see Chart A29). Although the modal teacher's age is similar between urban and rural schools, the share of young teachers is higher in big cities as compared to small cities and rural areas (see Chart A30). Nevertheless, schools with 
the Russian language of instruction usually employ significantly older teachers than schools with the Latvian language of instruction, other ethnic minority or mixed schools (see Chart A31). Moreover, gymnasiums typically employ somewhat older teachers than other secondary education institutions (see Chart A32).

Table 2 shows a significant difference in education outcomes between schools with higher and lower exam scores, i.e. within each school type, the average exam scores posted by $10 \%$ of top-performing schools are two thirds higher than those posted by $10 \%$ of low-performers. Schools with higher average exam scores are typically larger, teachers of such schools receive higher salaries and younger teachers are employed there. Although the share of teachers holding a master's degree is generally higher among schools with high exam scores, this mainly reflects the gymnasium effect. The number of pupils in top-performing schools is about two to three times larger than that of low-performing schools, and the difference between the average number of pupils is highly significant within each school type. More pupils and thus higher pupil-toteacher ratios allow teachers to receive higher salaries. The average monthly salary of teachers in top-performing schools is about 30\% higher (18\% higher for full-time work) than in low-performing schools, and this difference is again highly significant within each school type, except middle schools.

Table 2

Key school characteristics in schools with higher and lower average exam scores

\begin{tabular}{|c|c|c|c|c|c|c|c|c|}
\hline & \multicolumn{2}{|c|}{$\begin{array}{l}\text { General education } \\
\text { institutions (652) }\end{array}$} & \multicolumn{2}{|c|}{$\begin{array}{c}\text { Excluding } \\
\text { gymnasiums (602) }\end{array}$} & \multicolumn{2}{|c|}{$\begin{array}{c}\text { of which: } \\
\text { secondary schools } \\
\text { (299) } \\
\end{array}$} & \multicolumn{2}{|c|}{$\begin{array}{l}\text { of which: middle } \\
\text { schools (303) }\end{array}$} \\
\hline & best $10 \%$ & $\begin{array}{c}\text { worst } \\
10 \%\end{array}$ & best $10 \%$ & $\begin{array}{c}\text { worst } \\
10 \%\end{array}$ & best $10 \%$ & $\begin{array}{l}\text { worst } \\
10 \%\end{array}$ & best $10 \%$ & $\begin{array}{c}\text { worst } \\
10 \%\end{array}$ \\
\hline \multirow[t]{2}{*}{ Average exam score } & 1.26 & 0.75 & 1.23 & 0.74 & 1.23 & 0.77 & 1.23 & 0.72 \\
\hline & \multicolumn{2}{|c|}{$+* * *$} & \multicolumn{2}{|c|}{$+* * *$} & \multicolumn{2}{|c|}{$+* * *$} & \multicolumn{2}{|c|}{$+* * *$} \\
\hline \multirow[t]{2}{*}{ Number of pupils } & 449 & 141 & 422 & 139 & 665 & 263 & 139 & 81 \\
\hline & \multicolumn{2}{|c|}{$+* * *$} & \multicolumn{2}{|c|}{$+* * *$} & \multicolumn{2}{|c|}{$+* * *$} & \multicolumn{2}{|c|}{$+* *$} \\
\hline \multirow{2}{*}{$\begin{array}{l}\text { Teacher salary per } \\
\text { employee (euro) }\end{array}$} & 686 & 527 & 643 & 526 & 745 & 613 & 517 & 495 \\
\hline & \multicolumn{2}{|c|}{$+* * *$} & \multicolumn{2}{|c|}{$+* * *$} & \multicolumn{2}{|c|}{$+* * *$} & \multicolumn{2}{|c|}{+} \\
\hline \multirow{2}{*}{$\begin{array}{l}\text { Teacher salary for full- } \\
\text { time work (euro) }\end{array}$} & 572 & 485 & 536 & 485 & 575 & 513 & 491 & 480 \\
\hline & \multicolumn{2}{|c|}{$+* * *$} & \multicolumn{2}{|c|}{$+* * *$} & \multicolumn{2}{|c|}{$+* * *$} & \multicolumn{2}{|c|}{+} \\
\hline \multirow[t]{2}{*}{ Teacher age } & 47.2 & 47.8 & 46.3 & 47.9 & 45.4 & 48.8 & 47.5 & 47.3 \\
\hline & \multicolumn{2}{|c|}{-} & \multicolumn{2}{|c|}{$-* * *$} & \multicolumn{2}{|c|}{-*** } & \multicolumn{2}{|c|}{+} \\
\hline \multirow{2}{*}{$\begin{array}{l}\text { Share of teachers with } \\
\text { a master's degree (\%) }\end{array}$} & 29.9 & 20.9 & 27.3 & 21.9 & 28.5 & 30.0 & 25.0 & 20.5 \\
\hline & \multicolumn{2}{|c|}{$+* *$} & \multicolumn{2}{|c|}{+} & \multicolumn{2}{|c|}{-} & \multicolumn{2}{|c|}{+} \\
\hline \multirow[t]{2}{*}{ Teacher-to-pupil ratio } & 0.141 & 0.218 & 0.156 & 0.223 & 0.104 & 0.169 & 0.219 & 0.235 \\
\hline & \multicolumn{2}{|c|}{ - $* * *$} & -* & & - & & - & \\
\hline Computer-to-pupil & 0.252 & 0.372 & 0.251 & 0.379 & 0.194 & 0.291 & 0.322 & 0.422 \\
\hline ratio & & & -* & & - & & - & \\
\hline
\end{tabular}

Source: Author's calculations.

Notes. + (-): $10 \%$ of schools with higher exam scores have a higher (lower) mean than $10 \%$ of schools with lower exam scores. *, **, ***: the difference between the means is significant at $90 \%, 95 \%$ and $99 \%$ confidence levels respectively.

It seems that the negative correlation between pupils' performance on state exams and teachers' average age in a school is most important in secondary schools. This might 
mean that a large share of pre-retirement age teachers is associated with lower pupil performance in senior grades but not in the junior ones.

It should be noted that schools with low exam scores have a lot of teachers and computers per pupil. At first glance, this result might seem counterintuitive. However, a small number of pupils per teacher means low teacher salaries with prospective impact on education performance. Meanwhile, many computers per pupil may reflect a small number of pupils in the respective school. This result might mean that schools are either well-equipped with computers and therefore the marginal product of an additional computer is rather low; or that the number of computers does not transmit automatically into better education outcomes since the efficiency of computer usage is also important.

30 top-performing secondary and middle schools are presented in Tables A1 and A2 respectively. It is evident that the average exam score of top-performing middle schools is similar to that of top-performing secondary schools. Moreover, schools with high pupil performance are located in different regions and have different languages of instruction.

It is obvious that some school characteristics correlate with each other. For instance, ethnic minority schools (lower exam scores) are typically located in the capital and other big cities (higher exam scores), they are larger (higher exam scores) and employ more senior teachers (lower exam scores). This makes correlations and one-factor regressions (the methods predominantly used so far to analyse factors of pupil education performance in Latvia) not very useful for identifying which school characteristics are real drivers of pupil performance; they are also potentially misleading. Therefore, we proceed with a multifactor analysis.

\section{MULTIFACTOR ANALYSIS}

We use three different methods in the multifactor analysis section, i.e. the multifactor weighted least squares regressions, Oaxaca-Ransom decompositions and implementation of the SFA.

\subsection{Weighted least squares regression}

We find that higher exam scores are consistently associated with a higher number of pupils in a school (irrespective of whether a teacher's salary is or is not included in a regression) and younger teachers. Both these factors are highly significant regardless of whether a school sample covers the full dataset (652 schools; except vocational, evening and extramural schools) or excludes gymnasiums and middle schools (see Table 3). The positive link between school size and pupil performance is in line with the literature (Burney et al. (2013), Huguenin (2015), Essid et al. (2013), Pereira and Moreira (2007)). The previous findings regarding the relationship between teacher experience and pupil performance were ambiguous with some studies claiming a positive relation while others - a negative one. Perhaps, a negative association in the case of Latvia is country-specific and might reflect the fact that teachers in the country are one of the most senior among the EU countries.

The number of teachers and computers per pupil as well as the share of teachers with a master's degree do not affect exam scores in a systematic and statistically significant way; although the respective regression coefficients are always positive, they show a 
borderline significance at best. Again, only the borderline statistical significance may mirror Latvia's specifics. For instance, Eurostat data reveal that the number of teachers per pupil in Latvia is the highest in the EU, and thus any further increases (with other factors remaining constant) would have limited gains in terms of education performance. Similarly, if the number of computers is sufficient, the marginal product of an additional computer is rather modest. Finally, rather high prevalence of a master's degree among teachers may make this variable a rather weak proxy for motivation and other personal characteristics of an individual.

Private schools usually outperform the public ones, and this result is consistent with the literature (Alexander et al. (2010), Hirao (2012); Pereira and Moreira (2007), Crespo-Cebada et al. (2014)). Similarly, schools with the Latvian language of instruction show higher exam scores than ethnic minority schools (schools with the Russian language of instruction, other ethnic minority schools and mixed schools) even after controlling for other observable factors.

Socio-economic indicators in a municipality proxied with the unemployment rate and average net salary do not have a noteworthy impact on the average exam scores. It also seems that urban schools do not outperform rural schools after controlling for other observable factors; we will examine this observation in more detail through Oaxaca-Ransom decompositions. Finally, the share of girls among pupils has a positive sign, while the share of repeaters has a negative sign, as expected.

Table 3

Factors related to school average exam score (both public and private schools)

\begin{tabular}{|c|c|c|c|}
\hline & All schools & $\begin{array}{r}\text { Excluding } \\
\text { gymnasiums }\end{array}$ & $\begin{array}{r}\text { Including } \\
\text { secondary schools } \\
\end{array}$ \\
\hline In (number of pupils) & $0.072 * * *(0.016)$ & $0.058 * * *(0.013)$ & $0.086 * * *(0.018)$ \\
\hline Teacher age & $-0.006 * * *(0.002)$ & $-0.007 * * *(0.002)$ & $-0.011 * * *(0.003)$ \\
\hline Teacher-to-pupil ratio & $0.217 * *(0.110)$ & $0.117(0.090)$ & $0.083(0.102)$ \\
\hline $\begin{array}{l}\text { Share of teachers with a } \\
\text { master's degree (\%) }\end{array}$ & $0.043 *(0.022)$ & $0.036(0.025)$ & $0.046(0.029)$ \\
\hline Computer-to-pupil ratio & $0.074(0.064)$ & $0.007(0.066)$ & $0.160 *(0.095)$ \\
\hline Private school & $0.144 * * *(0.027)$ & $0.141^{* * *}(0.026)$ & $0.159 * * *(0.036)$ \\
\hline Russian language of instruction & $-0.091 * * *(0.023)$ & $-0.061 * * *(0.018)$ & $-0.048 * *(0.021)$ \\
\hline Other language of instruction & $-0.066 * * *(0.023)$ & $-0.050 * *(0.022)$ & $-0.054 * *(0.024)$ \\
\hline Unemployment rate (\%) & $-0.003(0.002)$ & $-0.003(0.002)$ & $-0.003(0.002)$ \\
\hline $\begin{array}{l}\text { Average salary in a } \\
\text { municipality (hundreds of euro) }\end{array}$ & $0.003(0.009)$ & $-0.001(0.009)$ & $-0.001(0.010)$ \\
\hline Big city & $-0.004(0.017)$ & $-0.022(0.018)$ & $-0.019(0.021)$ \\
\hline Small city & $-0.018(0.016)$ & $-0.030 *(0.016)$ & $-0.021(0.019)$ \\
\hline Share of girls & $0.615^{* * *}(0.139)$ & $0.451 * * *(0.122)$ & $0.517 * * *(0.176)$ \\
\hline Share of repeaters & $-1.761 * * *(0.241)$ & $-1.544^{* * *}(0.201)$ & $-1.653 * * *(0.282)$ \\
\hline Constant & $0.579 * * *(0.157)$ & $0.871^{* * *}(0.151)$ & $0.798 * * *(0.211)$ \\
\hline $\mathrm{R} 2$ & 0.368 & 0.324 & 0.406 \\
\hline F-statistics & 22.14 & 16.95 & 12.78 \\
\hline Observations & 652 & 602 & 299 \\
\hline
\end{tabular}

Source: Author's calculations.

Notes. *,**, ***: the coefficient is statistically significant at $90 \%, 95 \%$ and $99 \%$ confidence levels respectively. Standard errors are in parentheses. 
One may consider the share of repeaters being endogenous with respect to school performance and question the inclusion of this indicator into the equation. However, some schools may unofficially specialise in education of disadvantaged pupils; this is a factor which should be taken into account but which is difficult to measure objectively. Therefore, we include the share of repeaters as the only observable factor which may proxy unfavourable family characteristics (apart from general socioeconomic conditions in a municipality). The significance of other factors is robust subject to the exclusion of this variable.

The fact that different researchers find different effects of some variables may suggest non-linear (reverse $U$ shaped) relationship between the respective variable and exam scores. If this is the case, one can detect, e.g. the optimal teacher-to-pupil ratio or school size. We test for possible non-linearities by introducing squared terms into the regression for four variables, i.e. the number of pupils in a school, teacher-to-pupil ratio, teacher age and computer-to-pupil ratio. The results suggest that there is no evidence of non-linear relationship regarding the first three variables. It is only the latter variable, the computer-to-pupil ratio, that shows a weak evidence of non-linear relation; however, $F$-statistics still speaks in favour of the linear specification (see Table A3). These results might reflect Latvian specifics, i.e. if particular factor endowments in a vast majority of schools are either below or above the optimum, the models based on Latvian data would fail to show non-linear effects. It should also be noted that the linear relation between the teacher salary/age and exam scores is evident from Charts 3, 4, A18 and A25. Therefore, we proceed with the linear specification.

To examine the role played by a teacher salary in education performance of pupils, we repeated regressions for a subset of public schools (data on private school teacher salaries are not available). We find a positive and robust association between a teacher salary for full-time work and exam scores (see Table 4). However, the statistical significance of teacher salary in some cases weakens when it enters the equation together with the number of pupils, reflecting a strong positive correlation between these two variables (see Table A4). With the correlation coefficient of 0.72 , the impact of a teacher salary for full-time work may not be precisely separated from the impact of school size (since teachers in bigger schools typically have larger workloads, the correlation between a teacher salary per employee and the number of pupils is even higher, i.e. 0.81). All other factors that were previously found to be statistically significant, retain their statistical significance.

The possible reverse causality is often an issue in empirical research, and this paper is not an exception. For instance, exam scores might affect the size of a school if parents try to send their children to the best-performing schools. A good instrument in this case would be the physical size of a school (the number of classrooms, their area in square metres). This indicator is exogenous in the medium run and likely correlates with the number of pupils. But, unfortunately, it was not available in the datasets used by us. While acknowledging the possibility of the reverse causality, we should note that it does not preclude an impact of school size on education performance as the number of pupils in the best schools cannot grow unlimitedly. For instance, a school built for 100 pupils can theoretically educate 120 pupils, but not 1000 . Similarly, exam scores might affect a teacher salary as municipalities may pay some bonuses for high exam scores. But even in this case a school aiming to employ good teachers should offer even higher salaries to attract them from the best schools. 
Table 4

Factors related to school average exam score (public schools)

\begin{tabular}{|c|c|c|c|}
\hline & All public schools & $\begin{array}{r}\text { Excluding } \\
\text { gymnasiums }\end{array}$ & $\begin{array}{r}\text { Including public } \\
\text { secondary schools }\end{array}$ \\
\hline $\begin{array}{l}\text { Teacher salary for full-time } \\
\text { work (hundreds of euro) }\end{array}$ & $0.072 * * *(0.018)$ & $0.035 * *(0.016)$ & $0.040^{* *}(0.019)$ \\
\hline Teacher age & $-0.006 * * *(0.002)$ & $-0.008^{* * *}(0.002)$ & $-0.013 * * *(0.003)$ \\
\hline Teacher-to-pupil ratio & $-0.097(0.146)$ & $-0.252 *(0.138)$ & $-0.586 * *(0.286)$ \\
\hline $\begin{array}{l}\text { Share of teachers with a } \\
\text { master's degree (\%) }\end{array}$ & $0.033(0.023)$ & $0.040(0.026)$ & $0.051 *(0.030)$ \\
\hline Computer-to-pupil ratio & $0.015(0.066)$ & $-0.039(0.071)$ & $0.124(0.105)$ \\
\hline Russian language of instruction & $-0.074 * * *(0.022)$ & $-0.057 * * *(0.019)$ & $-0.046^{* *}(0.021)$ \\
\hline Other language of instruction & $-0.048^{* *}(0.024)$ & $-0.040 *(0.024)$ & $-0.045 *(0.027)$ \\
\hline Unemployment rate (\%) & $-0.001(0.002)$ & $-0.002(0.002)$ & $-0.002(0.002)$ \\
\hline $\begin{array}{l}\text { Average salary in a municipality } \\
\text { (hundreds of euro) }\end{array}$ & $-0.002(0.009)$ & $-0.003(0.009)$ & $-0.002(0.011)$ \\
\hline Big city & $0.023(0.019)$ & $0.003(0.019)$ & $0.010(0.024)$ \\
\hline Small city & $-0.018(0.016)$ & $-0.021(0.017)$ & $-0.016(0.020)$ \\
\hline Share of girls & $0.597 * * *(0.156)$ & $0.526^{* * *}(0.132)$ & $0.611^{* * *}(0.198)$ \\
\hline Share of repeaters & $-1.993 * * *(0.371)$ & $-1.704 * * *(0.324)$ & $-2.027^{* * *}(0.652)$ \\
\hline Constant & $0.697 * * *(0.155)$ & $1.047 * * *(0.161)$ & $1.180 * * *(0.213)$ \\
\hline R2 & 0.376 & 0.302 & 0.378 \\
\hline F-statistics & 23.82 & 14.54 & 10.87 \\
\hline Observations & 624 & 579 & 281 \\
\hline
\end{tabular}

Source: Author's calculations.

Notes. *, **, ***: the coefficient is statistically significant at $90 \%, 95 \%$ and $99 \%$ confidence levels respectively. Standard errors are in parentheses.

Next, we turn to analysing exam score determinants by grades and subjects.

The multifactor analysis confirms a larger effect of school characteristics on Grade 12 exam scores compared to Grade 9 - the evidence already established when carrying out the one-factor analysis. However, in both cases higher exam scores are consistently positively related to school size and/or teacher salaries and negatively to teacher age (see Table 5). 
Table 5

Factors related to school average exam score in Grades 9 and 12 (public schools)

\begin{tabular}{|c|c|c|c|}
\hline & $\begin{array}{r}\text { Grade } 12 \\
\text { (secondary } \\
\text { schools and } \\
\text { gymnasiums) }\end{array}$ & $\begin{array}{r}\text { Grade } 12 \text { (only } \\
\text { secondary } \\
\text { schools) }\end{array}$ & Grade 9 \\
\hline In (number of pupils) & $0.105^{* * *}(0.030)$ & $0.104 * * *(0.031)$ & $0.042 * * *(0.016)$ \\
\hline $\begin{array}{l}\text { Teacher salary for full-time } \\
\text { work (hundreds of euro) }\end{array}$ & $0.095 * * *(0.022)$ & $0.034(0.028)$ & $0.042 * * *(0.015)$ \\
\hline Teacher age & $-0.014 * * *(0.003)$ & $-0.016 * * *(0.004)$ & $-0.004 * *(0.002)$ \\
\hline Teacher-to-pupil ratio & $0.290(0.546)$ & $-0.300(0.499)$ & $0.136(0.164)$ \\
\hline $\begin{array}{l}\text { Share of teachers with a } \\
\text { master's degree (\%) }\end{array}$ & $0.068 *(0.035)$ & $0.058(0.040)$ & $0.010(0.023)$ \\
\hline Computer-to-pupil ratio & $0.394 * * *(0.149)$ & $0.298 *(0.169)$ & $0.030(0.069)$ \\
\hline Russian language of instruction & $-0.100 * * *(0.026)$ & $-0.075 * * *(0.026)$ & $-0.032 *(0.019)$ \\
\hline Other language of instruction & $-0.094 * *(0.039)$ & $-0.090 * *(0.038)$ & $-0.029 *(0.017)$ \\
\hline Unemployment rate (\%) & $0.003(0.003)$ & $0.001(0.003)$ & $-0.002(0.002)$ \\
\hline $\begin{array}{l}\text { Average salary in municipality } \\
\text { (hundreds of euro) }\end{array}$ & $-0.004(0.014)$ & $0.001(0.015)$ & $-0.010(0.008)$ \\
\hline Big city & $0.019(0.031)$ & $-0.027(0.036)$ & $0.003(0.016)$ \\
\hline Small city & $-0.021(0.029)$ & $-0.038(0.030)$ & $-0.006(0.014)$ \\
\hline Share of girls (Grade 12) & $0.276 * * *(0.078)$ & $0.246 * * *(0.079)$ & \\
\hline Share of repeaters (Grade 12) & $-0.994 * * *(0.355)$ & $-0.837 * *(0.361)$ & \\
\hline Share of girls (Grade 9) & & & $0.178 * * *(0.045)$ \\
\hline Share of repeaters (Grade 9) & & & $-0.502 * * *(0.100)$ \\
\hline Constant & $0.316(0.330)$ & $0.854 * * *(0.300)$ & $0.735 * * *(0.147)$ \\
\hline $\mathrm{R} 2$ & 0.428 & 0.379 & 0.270 \\
\hline F-statistics & 13.93 & 10.47 & 14.70 \\
\hline Observations & 318 & 273 & 620 \\
\hline
\end{tabular}

Source: Author's calculations.

Notes. *, **, ***: the coefficient is statistically significant at $90 \%, 95 \%$ and $99 \%$ confidence levels respectively. Standard errors are in parentheses.

Regarding Grade 12 exams, the association between the teacher age and exam scores is consistently negative in all subjects of the state centralised exams, i.e. English, mathematics and Latvian (see Table 6).

A positive link between the share of teachers holding a master's degree and exam scores is significant only in relation to mathematics exam. This is broadly in line with the literature (Clotfelter et al. (2007), Harris and Sass (2008), Chingos and Peterson (2011)). Mathematics is also the only compulsory subject in which repeaters earn significantly lower scores than other pupils.

It should be noted that ethnic minority schools have considerably lower Latvian exam scores than schools with the Latvian language of instruction. This difference is, at least partly, equitable since it is logical to expect that pupils whose mother tongue is Latvian (a vast majority of pupils attending schools with the Latvian language of instruction) achieve a higher exam score than pupils for whom Latvian is a second language. 
Interestingly, ethnic minority schools have lower English exam scores even after controlling for other observable factors. Meanwhile, schools with the Russian language of instruction have a significantly higher mathematics exam score than schools with the Latvian language of instruction as well as other ethnic minority and mixed schools.

Table 6

Factors related to Grade 12 average exam score by subject (public schools)

\begin{tabular}{|c|c|c|c|}
\hline & $\begin{array}{r}\text { English } \\
\text { (Grade 12) }\end{array}$ & $\begin{array}{r}\text { Mathematics } \\
\text { (Grade 12) }\end{array}$ & $\begin{array}{r}\text { Latvian } \\
\text { (Grade 12) }\end{array}$ \\
\hline In (number of pupils) & $0.119 * * *(0.030)$ & $0.085 * *(0.041)$ & $0.111 * * *(0.032)$ \\
\hline $\begin{array}{l}\text { Teacher salary for full-time } \\
\text { work (hundreds of euro) }\end{array}$ & $0.064^{* * *}(0.021)$ & $0.143^{* * *}(0.033)$ & $0.078 * * *(0.020)$ \\
\hline Teacher age & $-0.013 * * *(0.003)$ & $-0.016 * * *(0.005)$ & $-0.013 * * *(0.003)$ \\
\hline Teacher-to-pupil ratio & $0.382(0.548)$ & $0.080(0.836)$ & $0.416(0.514)$ \\
\hline $\begin{array}{l}\text { Share of teachers with a } \\
\text { master's degree (\%) }\end{array}$ & $0.044(0.037)$ & $0.111 * *(0.050)$ & $0.048(0.032)$ \\
\hline Computer-to-pupil ratio & $0.318 *(0.162)$ & $0.439 * *(0.220)$ & $0.425 * * *(0.143)$ \\
\hline Russian language of instruction & $-0.112 * * *(0.026)$ & $0.130 * * *(0.039)$ & $-0.317 * * *(0.023)$ \\
\hline Other language of instruction & $-0.077 *(0.039)$ & $-0.014(0.049)$ & $-0.193 * * *(0.044)$ \\
\hline Unemployment rate (\%) & $-0.005(0.004)$ & $0.012 * * *(0.004)$ & $0.000(0.003)$ \\
\hline $\begin{array}{l}\text { Average salary in municipality } \\
\text { (hundreds of euro) }\end{array}$ & $0.019(0.014)$ & $-0.018(0.018)$ & $-0.012(0.013)$ \\
\hline Big city & $0.025(0.033)$ & $0.048(0.039)$ & $-0.018(0.034)$ \\
\hline Small city & $-0.003(0.031)$ & $-0.044(0.039)$ & $-0.017(0.031)$ \\
\hline Share of girls (Grade 12) & $0.175 * *(0.079)$ & $0.248 * *(0.114)$ & $0.404^{* * *}(0.071)$ \\
\hline Share of repeaters (Grade 12) & $-0.652(0.487)$ & $-1.784 * * *(0.438)$ & $-0.525(0.319)$ \\
\hline Constant & $0.348(0.135)$ & $0.218(0.508)$ & $0.381(0.298)$ \\
\hline $\mathrm{R} 2$ & 0.425 & 0.321 & 0.667 \\
\hline F-statistics & 15.30 & 11.00 & 40.08 \\
\hline Observations & 317 & 318 & 318 \\
\hline
\end{tabular}

Source: Author's calculations.

Notes. $*, * *, * * *$ : the coefficient is statistically significant at $90 \%, 95 \%$ and $99 \%$ confidence levels respectively. Standard errors are in parentheses.

Grade 9 exam scores compared to those of Grade 12 have somewhat weaker association with the key school characteristics, such as school size and/or teacher salary and teacher age (see Table A5).

Ethnic minority schools still have significantly lower English exam scores than schools with the Latvian language of instruction; in Grade 9 this difference is even bigger in magnitude than in Grade 12. School premium in mathematics exam is also present in schools with the Russian language of instruction, but in Grade 9 it is smaller than in Grade 12. 


\subsection{Oaxaca-Ransom decomposition}

The biggest unsolved puzzle to date is the following: why does the one-factor analysis show that schools located in the capital or in other big cities have considerably higher exam scores than rural schools, while multifactor regressions do not point to school location as a significant determinant of exam scores? This might mean that the difference in exam scores between urban and rural schools is mostly driven by other observable factors. To shed light on this issue, we examine the difference between the exam scores posted by schools in different locations by implementing the OaxacaRansom decomposition.

First, we examine whether any factors can explain the well-known gap between urban and rural school performance.

On average, urban schools post about 7\% higher exam scores than the rural ones, and this difference is highly significant (see Table 7). However, it is fully explained by different observed school characteristics and control factors, leaving the unexplained part statistically insignificant and even with an opposite sign. The main reason why urban schools have, on average, higher exam scores is that these schools are larger and their teachers receive higher salaries. Second, the pupil structure differs among schools in different locations. Urban schools have a larger share of girls (who have higher exam scores than boys) and a smaller share of repeaters (who have lower exam scores than regular pupils ${ }^{6}$ ). Besides, urban schools have a larger share of teachers holding a master's degree. Meanwhile, the ethnic origin of pupils is a significant factor that plays in favour of rural schools as these schools include a larger share of schools with the Latvian language of instruction and a smaller one with the Russian language of instruction.

Other factors do not play a significant role in explaining the urban-rural exam score gap. Some factors are significant determinants of exam scores, but their values are similar in cities and villages. For instance, there is a significant negative relation between the teacher age and exam scores, but the teacher age is broadly the same across urban and rural schools. Other factors are significantly different between cities and villages, but they have only a limited impact on pupil education performance. For instance, rural areas have higher unemployment rates and lower wage levels; however, the association between socio-economic indicators of a municipality and the average exam scores is rather weak.

It should also be noted that the results of the Oaxaca-Ransom decomposition are similar irrespective of whether the regression coefficients were obtained from the equation that included or excluded the rural school dummy. The base specification employed in this paper does not include school location dummies into the regression (the Neumark approach), but the results of an alternative specification are similar.

\footnotetext{
${ }^{6}$ The share of repeaters might be considered as partly endogenous to school performance. However, the results of the Oaxaca-Ransom decomposition are almost robust to the exclusion of repeaters variable.
} 
Table 7

Exam score difference between urban and rural schools: the Oaxaca-Ransom decomposition

\begin{tabular}{|l|r|r|}
\hline $\begin{array}{l}\text { School location dummy in } \\
\text { regressions }\end{array}$ & $\begin{array}{r}\text { Excluded (the Neumark } \\
\text { approach; "omega") }\end{array}$ & Included ("pooled") \\
\hline Urban school & \multicolumn{2}{|c|}{$1.043^{* * *}(0.008)$} \\
\hline Rural school & \multicolumn{2}{|c|}{$0.977^{* * *}(0.008)$} \\
\hline Difference & \multicolumn{2}{|c|}{$0.066^{* * *}(0.011)$} \\
\hline Explained part & $0.068^{* * *}(0.010)$ & $0.071^{* * *}(0.013)$ \\
\hline ln (number of pupils) & $0.047^{* *}(0.019)$ & $0.050^{* *}(0.020)$ \\
\hline $\begin{array}{l}\text { Teacher salary for full-time work } \\
\text { (hundreds of euro) }\end{array}$ & $0.030^{* * *}(0.010)$ & $0.031^{* * *}(0.010)$ \\
\hline Teacher age & $-0.018^{*}(0.011)$ & $0.000(0.000)$ \\
\hline Teacher-to-pupil ratio & $0.003^{*}(0.002)$ & $-0.019^{*}(0.011)$ \\
\hline $\begin{array}{l}\text { Share of teachers with a master's } \\
\text { degree }\end{array}$ & $0.006(0.008)$ & $0.003^{*}(0.002)$ \\
\hline Computer-to-pupil ratio & $-0.016^{* * *}(0.003)$ & $-0.016^{* * *}(0.003)$ \\
\hline Latvian language of instruction & $-0.009^{* * *}(0.003)$ & $-0.009^{* * *}(0.003)$ \\
\hline Russian language of instruction & $-0.001(0.001)$ & $-0.001(0.001)$ \\
\hline Other language of instruction & $0.003(0.004)$ & $0.003(0.004)$ \\
\hline Unemployment rate (\%) & $0.001(0.006)$ & $0.001(0.006)$ \\
\hline $\begin{array}{l}\text { Average salary in a municipality } \\
\text { (hundreds of euro) }\end{array}$ & $0.014^{* * *}(0.003)$ & $0.014^{* * *}(0.003)$ \\
\hline Share of girls & $0.009^{* * *}(0.003)$ & $0.009^{* * *}(0.003)$ \\
\hline Share of repeaters & $-0.002(0.006)$ & $-0.005(0.014)$ \\
\hline Unexplained part & 287 & \\
\hline Observations (urban schools) & & \\
\hline Observations (rural schools) & & \\
\hline Observations (total) & & \\
\hline & & \\
\hline
\end{tabular}

Source: Author's calculations.

Notes: *,**, $* * *$ : the coefficient is statistically significant at $90 \%, 95 \%$ and $99 \%$ confidence levels respectively. Standard errors are in parentheses.

Next we check the extent to which observable characteristics can explain the $5 \%$ exam score difference between schools located in big cities and those located in small cities and rural areas. Again, the main factor behind the exam score gap is that schools in big cities are attended by more pupils and their teachers receive higher salaries, leaving the unexplained part statistically insignificant (see Chart 5 and Table A6). Meanwhile, the ethnic origin of pupils plays in favour of schools located in small cities and villages (these locations have a higher share of schools with the Latvian language of instruction and a smaller share of schools with the Russian language of instruction). 


\section{Chart 5}

Exam score difference between schools of different locations and types: the Oaxaca-Ransom decomposition (percentage points)

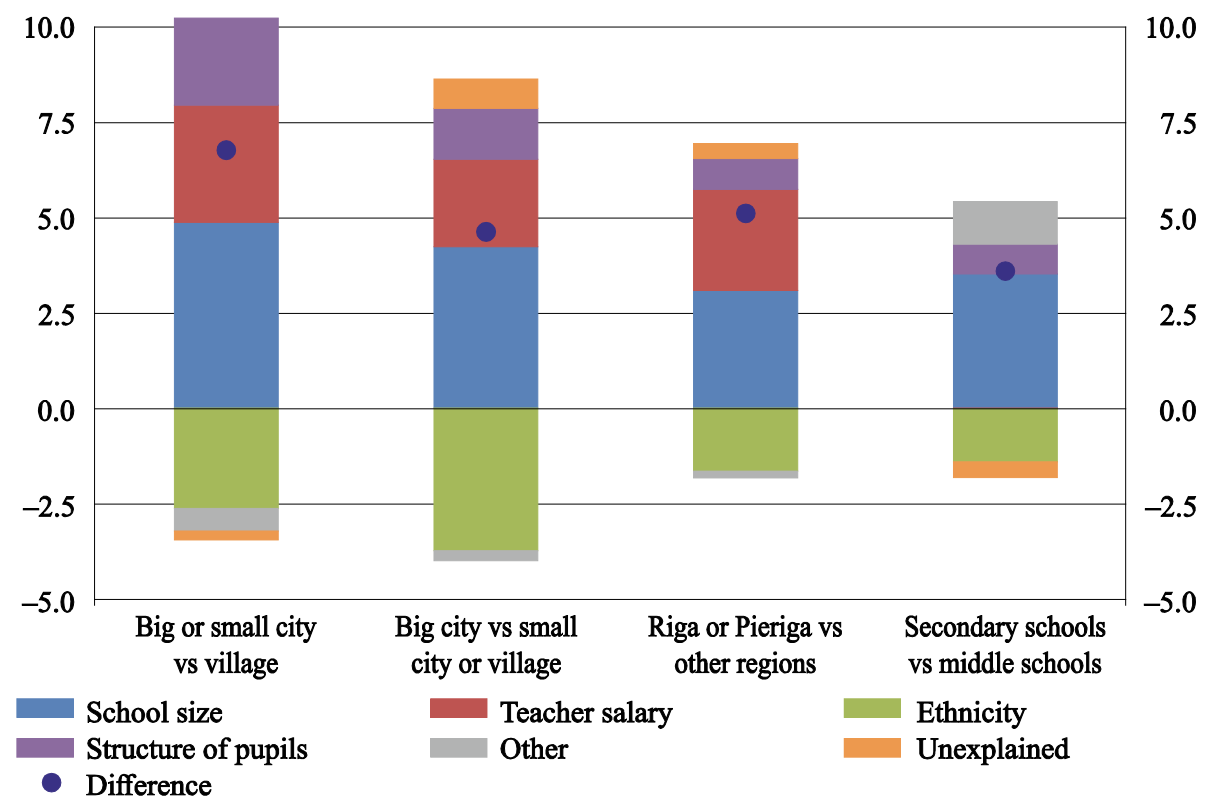

Sources: Ministry of Education and Science data and the author's calculations.

Then we check whether the capital city region has any additional unobservable factors that increase the average exam scores by more than $5 \%$ compared to other regions of the country. The Oaxaca-Ransom decomposition shows that the unexplained part is small in magnitude and statistically insignificant. Schools in the capital city region are, on average, bigger and their teachers typically receive higher salaries. These are the main factors behind relatively high exam scores (see Table A7).

Finally, we found that almost $4 \%$ of the exam score premium of secondary schools as compared to middle schools is mainly driven by the size of secondary schools. The exam score difference between secondary and middle schools would be even greater if the ethnic origin of pupils did not play a statistically significant role in favour of middle schools (see Table A8).

Overall, the Oaxaca-Ransom decomposition results show that school location is not a significant determinant of education performance of pupils. Schools in the capital and other big cities perform better because they are larger and their teachers receive higher salaries. This means that pupils in rural areas are not condemned to lower quality of secondary education compared to their urban counterparts. Making rural schools perform better is within policy tools.

\subsection{Stochastic Frontier Analysis}

Finally, we ran the SFA and employed variables of school size together with those of school location as joint possible efficiency determinants. This exercise may also be regarded as a robustness check of our earlier findings.

In a narrow sense, there are only two inputs in school "production function", i.e. the number of teachers and computers per pupil. However, since we have previously shown that the relation between exam scores and quantitative inputs is rather weak 
and in addition these inputs can be correlated with other school characteristics playing a significant role in the learning process, we employed quite a broad range of inputs. In addition to the traditional inputs like human capital (the number of teachers and their qualification) and physical capital (computers), we also included pupil structure variables (the share of girls and repeaters) as frontier determinants as well as dummies, i.e. the Latvian language of instruction, state gymnasium and gymnasium (since the latter two types of schools might have more capable applicants).

The SFA results confirm that qualitative inputs are more important than the quantitative ones for a school to achieve higher scores in state exams. For instance, a teacher's salary once again proves to be one of the key inputs to education quality. Also, the share of the teachers holding a master's degree shows a positive sign and is significant in some input combinations (the same applies to teacher age which has a negative sign). Moreover, the number of teachers and computers per pupil are statistically insignificant.

Regarding inefficiency determinants, the school size measured as the number of pupils is consistently associated with lower inefficiency, i.e. closer distance to the stochastic frontier. Meanwhile, the school location is not a robust inefficiency determinant since the village dummy is not statistically significant and its coefficient has opposite signs in different specifications (see Table 8).

Table 8

Inputs determining teaching quality and school efficiency factors (average exam score)

\begin{tabular}{|c|c|c|c|}
\hline & (1) & (2) & (3) \\
\hline \multicolumn{4}{|l|}{$\begin{array}{l}\text { Inputs/stochastic frontier } \\
\text { determinants: }\end{array}$} \\
\hline Teacher-to-pupil ratio & $0.103(0.111)$ & $0.111(0.113)$ & $0.131(0.116)$ \\
\hline $\begin{array}{l}\text { Teacher salary for full-time } \\
\text { work }\end{array}$ & $0.029 * * *(0.011)$ & $0.029 * * *(0.011)$ & $0.053 * * *(0.011)$ \\
\hline Teacher age & $-0.003(0.002)$ & $-0.003(0.002)$ & $-0.002(0.002)$ \\
\hline $\begin{array}{l}\text { Share of teachers with a } \\
\text { master's degree }\end{array}$ & $0.023(0.019)$ & $0.023(0.020)$ & $0.035 *(0.020)$ \\
\hline Computer-to-pupil ratio & $-0.078(0.057)$ & $-0.080(0.057)$ & $-0.045(0.057)$ \\
\hline $\begin{array}{l}\text { Latvian language of } \\
\text { instruction }\end{array}$ & $0.068 * * *(0.013)$ & $0.067 * * *(0.013)$ & $0.077 * * *(0.013)$ \\
\hline Share of girls & $0.354 * * *(0.094)$ & $0.355 * * *(0.094)$ & $0.487 * * *(0.093)$ \\
\hline Share of repeaters & $-1.225^{* * *}(0.209)$ & $-1.222 * * *(0.209)$ & $-1.264^{* * *}(0.214)$ \\
\hline State gymnasium & $0.140 * * *(0.027)$ & $0.141^{* * *}(0.027)$ & \\
\hline Gymnasium & $0.073 * * *(0.027)$ & $0.075 * * *(0.028)$ & \\
\hline Constant & $0.811^{* * *}(0.116)$ & $0.804 * * *(0.117)$ & $0.578 * * *(0.112)$ \\
\hline \multicolumn{4}{|l|}{ Inefficiency determinants: } \\
\hline ln (number of pupils) & $-0.992 * * *(0.286)$ & $-1.082 * * *(0.369)$ & $-0.971 * *(0.412)$ \\
\hline Village & & $-0.272(0.652)$ & $0.035(0.730)$ \\
\hline Constant & $-1.217(1.275)$ & $-0.601(1.972)$ & $-1.497(2.197)$ \\
\hline Wald chi2 & $228.83^{* * *}$ & $224.98 * * *$ & $190.11^{* * *}$ \\
\hline Observations & 624 & 624 & 624 \\
\hline
\end{tabular}

Source: Author's calulations.

Notes. $*, * *, * * *$ : the coefficient is statistically significant at $90 \%, 95 \%$ and $99 \%$ confidence levels respectively. Standard errors are in parentheses. 
As a robustness check, we apply the SFA only to Grade 12 exams (specification 4), including an additional school location variable reflecting whether a school is located in Riga or Pieriga or in other regions (specification 6) and combine these two changes simultaneously (specification 5; see Table 9).

Table 9

Inputs determining teaching quality and school efficiency factors (grade 12 and the average exam score)

\begin{tabular}{|l|r|r|r|}
\hline & $\mathbf{( 4 )}$ & $\mathbf{( 5 )}$ & $\mathbf{( 6 )}$ \\
\hline $\begin{array}{l}\text { Inputs/stochastic frontier } \\
\text { determinants: }\end{array}$ & & & \\
\hline Teacher-to-pupil ratio & $-0.527(0.384)$ & $-0.577(0.386)$ & $0.104(0.113)$ \\
\hline $\begin{array}{l}\text { Teacher salary for full-time } \\
\text { work (hundreds of euro) }\end{array}$ & $0.042^{* *}(0.020)$ & $0.038^{*}(0.020)$ & $0.024^{* *}(0.012)$ \\
\hline Teacher age & $-0.014^{* * *}(0.003)$ & $-0.014^{* * *}(0.003)$ & $-0.003(0.002)$ \\
\hline $\begin{array}{l}\text { Share of teachers with a } \\
\text { master's degree }\end{array}$ & $0.062^{*}(0.032)$ & $0.064^{* *}(0.033)$ & $0.026(0.020)$ \\
\hline Computer-to-pupil ratio & $0.291^{* *}(0.125)$ & $0.304^{* *}(0.126)$ & $-0.081(0.056)$ \\
\hline $\begin{array}{l}\text { Latvian language of } \\
\text { instruction }\end{array}$ & $0.076^{* * *}(0.020)$ & $0.076^{* * *}(0.020)$ & $0.067^{* * *}(0.013)$ \\
\hline Share of girls (Grade 12) & $0.262^{* * *}(0.063)$ & $0.263^{* * *}(0.063)$ & \\
\hline Share of repeaters (Grade 12) & $-1.120^{* * *}(0.290)$ & $-1.113^{* * *}(0.289)$ & \\
\hline Share of girls & & & $0.366^{* * *}(0.094)$ \\
\hline Share of repeaters & & & $-1.223^{* * *}(0.208)$ \\
\hline State gymnasium & $0.175^{* * *}(0.035)$ & $0.180^{* * *}(0.035)$ & $0.148^{* * *}(0.027)$ \\
\hline Gymnasium & $0.069^{* *}(0.035)$ & $0.069^{* *}(0.035)$ & $0.076^{* * *}(0.028)$ \\
\hline Constant & $1.327^{* * *}(0.204)$ & $1.355^{* * *}(0.205)$ & $0.825^{* * *}(0.117)$ \\
\hline Inefficiency determinants: & & & \\
\hline ln (number of pupils) & $-1.350^{* * *}(0.477)$ & $-1.227^{* *}(0.492)$ & $-0.909^{* *}(0.359)$ \\
\hline Village & $0.227(0.526)$ & $0.195(0.525)$ & $-0.258(0.640)$ \\
\hline Riga or Pieriga & & $-0.472(0.579)$ & $-1.008(0.765)$ \\
\hline Constant & $2.438(2.758)$ & $1.899(2.827)$ & $-1.239(1.963)$ \\
\hline Wald chi2 & $201.70^{* * *}$ & $203.20^{* * *}$ & $226.55^{* * *}$ \\
\hline Observations & 318 & & 318 \\
\hline
\end{tabular}

Source: Author's calculations.

Notes. *, **, ***: the coefficient is statistically significant at $90 \%, 95 \%$ and $99 \%$ confidence levels respectively. Standard errors are in parentheses.

The results remain broadly similar. The school size is consistently associated with lower inefficiency, while no school location variable is significant. This would mean that also rural schools located outside the capital city region can achieve high education standards if they are large enough and invest in human resources. Furthermore, the teacher salary and teacher age (the latter with a negative sign) once again appear as crucial inputs to pupil education achievements. 


\section{CONCLUSIONS}

We combine data extracted from several publicly available and unavailable datasets on state exam scores, teacher salaries, various school characteristics and socioeconomic indicators of municipalities to find out which school characteristics are consistently associated with better performance of pupils on state centralised exams in Latvia. The resulting dataset for the academic year 2014/2015 includes information about 699 education institutions, but this paper includes an analysis of 299 secondary schools, 303 middle schools and 50 gymnasiums.

We find that exam scores are positively associated with the school size and teacher salaries, but negatively - with the teacher age. Meanwhile, quantitative inputs like the number of teachers and computers per pupil are not robust determinants of education performance, but the formal education degree of teachers shows borderline significance.

A substantial exam score difference between urban and rural schools is a well-known fact in Latvia. However, by employing multifactor weighted least squares regressions we show that rural and urban schools perform similarly if control factors are included in the equation. Furthermore, by employing the Oaxaca-Ransom decomposition we show that pupils in urban schools achieve better exam scores due to a larger school size, higher teacher salaries and a different structure of pupils rather than any unobservable factor that deteriorates rural school performance. We also show that schools in Latvia's regions could achieve exam scores similar to those demonstrated by schools in Riga and Pieriga if they had similar characteristics; the same applies to middle schools as compared to secondary schools. Although ethnic minority schools lag behind in Latvian and English exams, schools with the Russian language of instruction perform significantly better in mathematics exams.

Finally, by employing SFA models we show that the school size is a robust efficiency determinant, while the school location in the capital city or in other big city is not. This means that the rural schools located outside the capital city region can also achieve high education standards if they are large enough and invest in their human resources. There is also some evidence suggesting that qualitative inputs (the teacher salary, age and formal education degree) are more important factors of pupil education performance than quantitative inputs (the number of teachers and computers per pupil).

The bottom line is that structural reforms involving merger of schools and a rise in teacher salaries might bring non-negligible dividends in terms of education quality. Maintenance of many very small poorly performing schools hinders the increase in teacher salaries and attraction of young talent to the profession even though Latvia, compared to other EU countries, spends the largest share of its general budget on education. 


\section{APPENDIX}

Table A1

$10 \%$ of secondary schools with the highest average exam scores (2015)

\begin{tabular}{|c|c|c|c|c|c|c|}
\hline \multirow[t]{2}{*}{ School } & \multirow[t]{2}{*}{ Region } & \multirow[t]{2}{*}{ Location } & \multirow[t]{2}{*}{$\begin{array}{l}\text { Language of } \\
\text { instruction }\end{array}$} & \multicolumn{3}{|c|}{$\begin{array}{c}\text { Average exam score } \\
(\text { index; } \text { country average }=1)\end{array}$} \\
\hline & & & & Average & Grade 12 & Grade 9 \\
\hline $\begin{array}{l}\text { Daugavpils Krievu } \\
\text { vidusskola - licejs }\end{array}$ & Latgale & Big city & Russian & 1.343 & 1.385 & 1.301 \\
\hline $\begin{array}{l}\text { Alojas Ausekḷa } \\
\text { vidusskola }\end{array}$ & Pieriga & Small city & Latvian & 1.323 & 1.595 & 1.051 \\
\hline $\begin{array}{l}\text { Rīgas Centra humanitārā } \\
\text { vidusskola }\end{array}$ & Riga & Big city & Latvian & 1.322 & 1.425 & 1.220 \\
\hline Rīgas Franču licejs & Riga & Big city & Latvian & 1.319 & 1.413 & 1.225 \\
\hline Rīgas 64. vidusskola & Riga & Big city & Latvian & 1.299 & 1.435 & 1.163 \\
\hline Rīgas 40. vidusskola & Riga & Big city & Russian & 1.263 & 1.218 & 1.308 \\
\hline Daugavpils 3. vidusskola & Latgale & Big city & Russian & 1.262 & 1.298 & 1.226 \\
\hline Rīgas Juglas vidusskola & Riga & Big city & Latvian & 1.249 & 1.326 & 1.172 \\
\hline Rēzeknes 1. vidusskola & Latgale & Big city & Latvian & 1.239 & 1.381 & 1.097 \\
\hline Rīgas 34. vidusskola & Riga & Big city & Latvian & 1.237 & 1.228 & 1.246 \\
\hline $\begin{array}{l}\text { Privātā vidusskola } \\
\text { "Klasika" } \\
\end{array}$ & Riga & Big city & Other & 1.236 & 1.164 & 1.309 \\
\hline Rīgas Teikas vidusskola & Riga & Big city & Latvian & 1.236 & 1.256 & 1.216 \\
\hline Aglonas vidusskola & Latgale & Village & Latvian & 1.235 & 1.250 & 1.220 \\
\hline $\begin{array}{l}\text { Talsu Kristīgā } \\
\text { vidusskola }\end{array}$ & Kurzeme & Small city & Latvian & 1.231 & 1.273 & 1.188 \\
\hline Rīgas 49. vidusskola & Riga & Big city & Latvian & 1.230 & 1.274 & 1.186 \\
\hline Baldones vidusskola & Pieriga & Small city & Latvian & 1.224 & 1.261 & 1.186 \\
\hline $\begin{array}{l}\text { Andreja Upīša Skrīveru } \\
\text { vidusskola }\end{array}$ & Zemgale & Village & Latvian & 1.205 & 1.301 & 1.109 \\
\hline $\begin{array}{l}\text { Saldus novada } \\
\text { pašvaldības Druvas } \\
\text { vidusskola }\end{array}$ & Kurzeme & Village & Latvian & 1.198 & 1.244 & 1.151 \\
\hline Mārupes vidusskola & Pieriga & \begin{tabular}{|l|} 
Village \\
\end{tabular} & Latvian & 1.197 & 1.251 & 1.143 \\
\hline Rīgas 10. vidusskola & Riga & Big city & Russian & 1.197 & 1.174 & 1.220 \\
\hline Baltinavas vidusskola & Latgale & Village & Latvian & 1.197 & 1.374 & 1.020 \\
\hline Ādažu vidusskola & Pieriga & \begin{tabular}{|l|} 
Village \\
\end{tabular} & Other & 1.194 & 1.262 & 1.126 \\
\hline Olaines 1. vidusskola & Pieriga & Small city & Other & 1.192 & 1.308 & 1.076 \\
\hline $\begin{array}{l}\text { Rīgas Kultūru } \\
\text { vidusskola }\end{array}$ & Riga & Big city & Latvian & 1.191 & 1.226 & 1.155 \\
\hline $\begin{array}{l}\text { Privātā vidusskola } \\
\text { "Patnis" }\end{array}$ & Riga & Big city & Latvian & 1.188 & 1.273 & 1.102 \\
\hline Ventspils 4. vidusskola & Kurzeme & Big city & Latvian & 1.182 & 1.166 & 1.198 \\
\hline $\begin{array}{l}\text { Rīgas Purvciema } \\
\text { vidusskola }\end{array}$ & Riga & Big city & Russian & 1.181 & 1.163 & 1.198 \\
\hline Rīgas Hanzas vidusskola & Riga & Big city & Latvian & 1.178 & 1.185 & 1.170 \\
\hline Vaboles vidusskola & Latgale & Village & Latvian & 1.174 & 1.108 & 1.240 \\
\hline Špog̊u vidusskola & Latgale & Village & Other & 1.173 & 1.298 & 1.048 \\
\hline
\end{tabular}

Sources: Ministry of Education and Science data and the author's calculations. 
Table A2

$10 \%$ of middle schools with the highest average exam scores (2015)

\begin{tabular}{|c|c|c|c|c|}
\hline School & Region & Location & Language & $\begin{array}{r}\text { Average exam } \\
\text { score (index; } \\
\text { country average = 1) } \\
\end{array}$ \\
\hline Šk̦aunes pamatskola & Latgale & Village & Latvian & 1.410 \\
\hline Inešu pamatskola & Vidzeme & Village & Latvian & 1.410 \\
\hline Lapmežciema pamatskola & Pieriga & Village & Latvian & 1.350 \\
\hline Skujenes pamatskola & Vidzeme & Village & Latvian & 1.298 \\
\hline Drustu pamatskola & Vidzeme & Village & Latvian & 1.296 \\
\hline Jūrmalas Alternatīvā skola & Pieriga & Big city & Latvian & 1.296 \\
\hline Kārķu pamatskola & Vidzeme & Village & Latvian & 1.292 \\
\hline Kalvenes pamatskola & Kurzeme & Village & Latvian & 1.279 \\
\hline $\begin{array}{l}\text { Baumaņu Kārḷa Vilı̧̧enes } \\
\text { pamatskola }\end{array}$ & Pieriga & Village & Latvian & 1.274 \\
\hline Asūnes pamatskola & Latgale & Village & Latvian & 1.256 \\
\hline Balvu pamatskola & Latgale & Small city & Other & 1.253 \\
\hline Kalsnavas pamatskola & Vidzeme & Village & Latvian & 1.238 \\
\hline Daugavpils Saskanas pamatskola & Latgale & Big city & Other & 1.226 \\
\hline Liepājas Katoḷu pamatskola & Kurzeme & Big city & Latvian & 1.226 \\
\hline Aulejas pamatskola & Latgale & Village & Latvian & 1.217 \\
\hline Tīnūžu pamatskola & Pieriga & Village & Latvian & 1.202 \\
\hline Sutru pamatskola & Latgale & Village & Latvian & 1.199 \\
\hline $\begin{array}{l}\text { Saldus novada pašvaldības Rubas } \\
\text { pamatskola }\end{array}$ & Kurzeme & Village & Latvian & 1.198 \\
\hline Carnikavas pamatskola & Pieriga & Village & Latvian & 1.198 \\
\hline Kristiāna Dāvida pamatskola & Vidzeme & Village & Latvian & 1.197 \\
\hline Viduču pamatskola & Latgale & Village & Latvian & 1.195 \\
\hline Priekulı pamatskola & Latgale & Village & Latvian & 1.186 \\
\hline Baldones Mūzikas pamatskola & Pieriga & Small city & Latvian & 1.172 \\
\hline Kolkas pamatskola & Kurzeme & Village & Latvian & 1.168 \\
\hline Pastendes pamatskola & Kurzeme & Village & Latvian & 1.167 \\
\hline Grundzāles pamatskola & Vidzeme & Village & Latvian & 1.160 \\
\hline Puzes pamatskola & Kurzeme & Village & Latvian & 1.156 \\
\hline Mežciema pamatskola & Riga & Big city & Latvian & 1.154 \\
\hline Slokas pamatskola & Pieriga & Big city & Latvian & 1.154 \\
\hline Privātā pamatskola "Maksima" & Riga & Big city & Russian & 1.154 \\
\hline
\end{tabular}

Sources: Ministry of Education and Science data and the author's calculations. 
Table A3

Factors related to school average exam score (all public and private schools)

\begin{tabular}{|c|c|c|c|c|}
\hline & (1) & (2) & (3) & $(4)$ \\
\hline In (number of pupils) & & $0.071 * * *(0.015)$ & $0.075^{* * *}(\mathbf{0 . 0 1 8})$ & $0.074 * * *(0.016)$ \\
\hline Number of pupils & $0.833(0.647)$ & & & \\
\hline Number of pupils (squared) & $0.001(0.000)$ & & & \\
\hline Teacher age & $-0.005 * *(0.002)$ & $0.016(0.044)$ & $-0.006 * * *(0.002)$ & $-0.006 * * *(0.002)$ \\
\hline Teacher age (squared) & & $0.000(0.000)$ & & \\
\hline Teacher-to-pupil ratio & $-0.036(0.086)$ & $0.216 * *(0.109)$ & $0.304(0.203)$ & $0.227 * *(0.112)$ \\
\hline Teacher-to-pupil ratio (squared) & & & $-0.052(0.061)$ & \\
\hline $\begin{array}{l}\text { Share of teachers with a master's } \\
\text { degree }(\%)\end{array}$ & $0.041 * *(0.021)$ & $0.043 *(0.022)$ & $0.043 *(0.022)$ & $0.043 *(0.022)$ \\
\hline Computer-to-pupil ratio & $0.047(0.061)$ & $0.072(0.064)$ & $0.067(0.065)$ & $0.129(0.090)$ \\
\hline Computer-to-pupil ratio (squared) & & & & $-0.061 *(0.036)$ \\
\hline Private school & $0.146 * * *(0.027)$ & $0.147 * * *(0.028)$ & $0.143^{* * *}(0.027)$ & $0.145^{* * *}(0.028)$ \\
\hline Russian language of instruction & $-0.101^{* * *}(0.024)$ & $-0.091^{* * *}(0.023)$ & $-0.091^{* * *}(0.023)$ & $-0.090 * * *(0.023)$ \\
\hline Other language of instruction & $-0.058 * *(0.023)$ & $-0.066 * * *(0.024)$ & $-0.066 * * *(0.023)$ & $-0.065 * * *(0.023)$ \\
\hline Unemployment rate (\%) & $-0.003(0.002)$ & $-0.003(0.002)$ & $-0.003(0.002)$ & $-0.003(0.002)$ \\
\hline $\begin{array}{l}\text { Average salary in a municipality } \\
\text { (hundreds of euro) }\end{array}$ & $-0.002(0.009)$ & $0.004(0.009)$ & $0.003(0.009)$ & $0.003(0.009)$ \\
\hline Big city & $0.019(0.017)$ & $-0.004(0.017)$ & $-0.004(0.017)$ & $-0.004(0.017)$ \\
\hline Small city & $0.006(0.015)$ & $-0.018(0.016)$ & $-0.018(0.016)$ & $-0.018(0.016)$ \\
\hline Share of girls & $0.622 * * *(0.137)$ & $0.617 * * *(0.138)$ & $0.613^{* * *}(0.140)$ & $0.613^{* * *}(0.139)$ \\
\hline Share of repeaters & $-1.696 * * *(0.225)$ & $-1.758 * * *(0.239)$ & $-1.758 * * *(0.241)$ & $-1.771 * * *(0.243)$ \\
\hline Constant & $0.948 * * *(0.129)$ & $0.081(1.080)$ & $0.558 * * *(0.170)$ & $0.564 * * *(0.159)$ \\
\hline R2 & 0.394 & 0.368 & 0.368 & 0.369 \\
\hline F-statistics & 20.79 & 20.54 & 20.89 & 20.61 \\
\hline Observations & 652 & 652 & 652 & 652 \\
\hline
\end{tabular}

Source: Author's calculations.

Notes. *, **, ***: the coefficient is statistically significant at $90 \%, 95 \%$ and $99 \%$ confidence levels respectively. Standard errors are in parentheses. 
Table A4

Factors related to school average exam score (public schools; with school size variable)

\begin{tabular}{|c|c|c|c|}
\hline & All public schools & $\begin{array}{r}\text { Excluding } \\
\text { gymnasiums }\end{array}$ & $\begin{array}{r}\text { of which: public } \\
\text { secondary schools }\end{array}$ \\
\hline In (number of pupils) & $0.056 * * *(0.017)$ & $0.052 * * *(0.016)$ & $0.078 * * *(0.023)$ \\
\hline $\begin{array}{l}\text { Teacher salary for full-time } \\
\text { work (hundreds of euro) }\end{array}$ & $0.057 * * *(0.018)$ & $0.017(0.018)$ & $0.021(0.021)$ \\
\hline Teacher age & $-0.006^{* * *}(0.002)$ & $-0.008 * * *(0.002)$ & $-0.012 * * *(0.003)$ \\
\hline Teacher-to-pupil ratio & $0.318(0.198)$ & $0.102(0.164)$ & $0.020(0.320)$ \\
\hline $\begin{array}{l}\text { Share of teachers with a } \\
\text { master's degree (\%) }\end{array}$ & $0.028(0.023)$ & $0.033(0.025)$ & $0.041(0.029)$ \\
\hline Computer-to-pupil ratio & $0.095(0.070)$ & $0.029(0.075)$ & $0.236 * *(0.108)$ \\
\hline $\begin{array}{l}\text { Russian language of } \\
\text { instruction }\end{array}$ & $-0.081 * * *(0.021)$ & $-0.061 * * *(0.019)$ & $-0.047 * *(0.021)$ \\
\hline Other language of instruction & $-0.057 * *(0.024)$ & $-0.050 * *(0.023)$ & $-0.053^{* *}(0.025)$ \\
\hline Unemployment rate (\%) & $-0.001(0.002)$ & $-0.003(0.002)$ & $-0.002(0.002)$ \\
\hline $\begin{array}{l}\text { Average salary in a } \\
\text { municipality (hundreds of } \\
\text { euro) }\end{array}$ & $-0.004(0.009)$ & $-0.004(0.009)$ & $-0.003(0.011)$ \\
\hline Big city & $0.003(0.018)$ & $-0.018(0.020)$ & $-0.012(0.024)$ \\
\hline Small city & $-0.032 *(0.017)$ & $-0.033 * *(0.017)$ & $-0.025(0.020)$ \\
\hline Share of girls & $0.556 * * *(0.154)$ & $0.463^{* * *}(0.130)$ & $0.533^{* * *}(0.194)$ \\
\hline Share of repeaters & $-1.926 * * *(0.350)$ & $-1.635^{* * *}(0.306)$ & $-1.924 * * *(0.586)$ \\
\hline Constant & $0.415 * *(0.185)$ & $0.830 * * *(0.170)$ & $0.750 * * *(0.247)$ \\
\hline R2 & 0.393 & 0.321 & 0.410 \\
\hline$F$-statistics & 22.30 & 14.72 & 11.45 \\
\hline Observations & 624 & 579 & 281 \\
\hline
\end{tabular}

Source: Author's calculations.

Notes. $*, * *, * * *$ : the coefficient is statistically significant at $90 \%, 95 \%$ and $99 \%$ confidence levels respectively. Standard errors are in parentheses. 
Table A5

Factors related to school average exam score in Grade 9 (by subject)

\begin{tabular}{|c|c|c|c|}
\hline & English (Grade 9) & $\begin{array}{r}\text { Mathematics } \\
\text { (Grade 9) } \\
\end{array}$ & Latvian (Grade 9) \\
\hline In (number of pupils) & $0.059 * * *(0.016)$ & $0.043 *(0.023)$ & $0.025(0.017)$ \\
\hline $\begin{array}{l}\text { Teacher salary for full-time } \\
\text { work (hundreds of euro) }\end{array}$ & $0.026 *(0.014)$ & $0.081 * * *(0.021)$ & $0.026 *(0.015)$ \\
\hline Teacher age & $-0.005 * *(0.002)$ & $-0.003(0.003)$ & $-0.004 *(0.002)$ \\
\hline Teacher-to-pupil ratio & $0.184(0.190)$ & $0.255(0.256)$ & $0.083(0.172)$ \\
\hline $\begin{array}{l}\text { Share of teachers with a } \\
\text { master's degree (\%) }\end{array}$ & $0.004(0.023)$ & $0.032(0.034)$ & $-0.009(0.024)$ \\
\hline Computer-to-pupil ratio & $-0.010(0.078)$ & $0.025(0.102)$ & $0.075(0.071)$ \\
\hline Russian language of instruction & $-0.187 * * *(0.018)$ & $0.059 * *(0.026)$ & $0.037 * *(0.019)$ \\
\hline Other language of instruction & $-0.133 * * *(0.021)$ & $0.028(0.025)$ & $0.023(0.021)$ \\
\hline Unemployment rate (\%) & $-0.002(0.002)$ & $-0.001(0.002)$ & $-0.003 *(0.002)$ \\
\hline $\begin{array}{l}\text { Average salary in a municipality } \\
\text { (hundreds of euro) }\end{array}$ & $0.021 * * *(0.008)$ & $-0.030 * * *(0.010)$ & $-0.019 * *(0.008)$ \\
\hline Big city & $0.003(0.019)$ & $0.015(0.025)$ & $-0.011(0.022)$ \\
\hline Small city & $-0.007(0.016)$ & $-0.023(0.021)$ & $0.008(0.018)$ \\
\hline Share of girls (Grade 9) & $0.132 * * *(0.050)$ & $0.193^{* * *}(0.068)$ & $0.231 * * *(0.044)$ \\
\hline Share of repeaters (Grade 9) & $-0.298 * *(0.137)$ & $-0.644 * * *(0.187)$ & $-0.553 * * *(0.083)$ \\
\hline Constant & $0.665^{* * *}(0.144)$ & $0.523 * *(0.220)$ & $0.915^{* * *}(0.159)$ \\
\hline $\mathrm{R} 2$ & 0.449 & 0.230 & 0.180 \\
\hline F-statistics & 37.64 & 11.05 & 9.43 \\
\hline Observations & 594 & 598 & 612 \\
\hline
\end{tabular}

Source: Author's calculations.

Notes. $* * *, * * *$ : the coefficient is statistically significant at $90 \%, 95 \%$ and $99 \%$ confidence levels respectively. Standard errors are in parentheses. 
Table A6

Explaining the exam score difference between schools located in big cities andthose located in small cities or villages

\begin{tabular}{|l|r|}
\hline Big city & $1.043^{* * *}(0.011)$ \\
\hline Small city or village & $0.995^{* * *}(0.007)$ \\
\hline Difference & $0.048^{* * *}(0.013)$ \\
\hline Explained part & $0.040^{* * *}(0.011)$ \\
\hline ln (number of pupils) & $0.044^{* *}(0.017)$ \\
\hline Teacher salary for full-time work (hundreds of euro) & $0.024^{* * *}(0.008)$ \\
\hline Teacher age & $0.001(0.001)$ \\
\hline Teacher-to-pupil ratio & $-0.017^{*}(0.010)$ \\
\hline Share of teachers with a master's degree (\%) & $0.003^{*}(0.002)$ \\
\hline Computer-to-pupil ratio & $0.006(0.008)$ \\
\hline Latvian language of instruction & $-0.023^{* * *}(0.005)$ \\
\hline Russian language of instruction & $-0.015^{* * *}(0.004)$ \\
\hline Other language of instruction & $-0.001(0.001)$ \\
\hline Unemployment rate (\%) & $0.003(0.005)$ \\
\hline Average salary in a municipality (hundreds of euro) & $0.002(0.009)$ \\
\hline Share of girls & $0.007^{* * *}(0.003)$ \\
\hline Share of repeaters & $0.007^{* *}(0.003)$ \\
\hline Unexplained part & $0.008(0.008)$ \\
\hline Observations (big city) & 171 \\
\hline Observations (village or small city) & 453 \\
\hline Observations (total) & 624 \\
\hline
\end{tabular}

Source: Author's calculations.

Notes. $* * *, * * *$ : the coefficient is statistically significant at $90 \%, 95 \%$ and $99 \%$ confidence levels respectively. Standard errors are in parentheses. 
Table A7

Explaining the exam score gap between schools located in Riga and Pieriga compared to those located in other regions of the country

\begin{tabular}{|l|r|}
\hline Riga and Pieriga & $1.045^{* * *}(0.010)$ \\
\hline Other region & $0.991^{* * *}(0.007)$ \\
\hline Difference & $0.053^{* * *}(0.012)$ \\
\hline Explained part & $0.049^{* * *}(0.010)$ \\
\hline ln (number of pupils) & $0.032^{* *}(0.013)$ \\
\hline Teacher salary for full-time work (hundreds of euro) & $0.028^{* * *}(0.009)$ \\
\hline Teacher age & $0.000(0.001)$ \\
\hline Teacher-to-pupil ratio & $-0.015^{*}(0.009)$ \\
\hline Share of teachers with a master's degree (\%) & $0.000(0.001)$ \\
\hline Computer-to-pupil ratio & $0.005(0.006)$ \\
\hline Latvian language of instruction & $-0.010^{* * *}(0.003)$ \\
\hline Russian language of instruction & $-0.008^{* * *}(0.003)$ \\
\hline Other language of instruction & $0.000(0.000)$ \\
\hline Unemployment rate (\%) & $0.005(0.008)$ \\
\hline Average salary in a municipality & $0.002(0.009)$ \\
\hline Share of girls & $0.003(0.002)$ \\
\hline Share of repeaters & $0.005^{* *}(0.003)$ \\
\hline Unexplained part & $0.004(0.008)$ \\
\hline Observations (Riga and Pieriga) & 191 \\
\hline Observations (other region) & 433 \\
\hline Observations (total) & 624 \\
\hline
\end{tabular}

Source: Author's calculations.

Notes. $*, * *, * * *$ : the coefficient is statistically significant at $90 \%, 95 \%$ and $99 \%$ confidence levels respectively. Standard errors are in parentheses. 
Table A8

Explaining exam score gap between secondary schools and middle schools

\begin{tabular}{|l|r|}
\hline Secondary school & $1.016^{* * *}(0.006)$ \\
\hline Middle school & $0.981^{* * *}(0.008)$ \\
\hline Difference & $0.035^{* * *}(0.010)$ \\
\hline Explained part & $0.039^{* * *}(0.009)$ \\
\hline ln (number of pupils) & $0.034^{* *}(0.017)$ \\
\hline Teacher salary for full-time work (hundreds of euro) & $-0.000(0.007)$ \\
\hline Teacher age & $-0.001(0.001)$ \\
\hline Teacher-to-pupil ratio & $-0.011(0.011)$ \\
\hline Share of teachers with a master's degree (\%) & $0.002(0.002)$ \\
\hline Computer-to-pupil ratio & $0.018^{* * *}(0.007)$ \\
\hline Latvian language of instruction & $-0.008^{* * *}(0.003)$ \\
\hline Russian language of instruction & $-0.005^{* *}(0.002)$ \\
\hline Other language of instruction & $-0.000(0.001)$ \\
\hline Unemployment rate (\%) & $0.004(0.002)$ \\
\hline Average salary in a municipality (hundreds of euro) & $-0.001(0.004)$ \\
\hline Share of girls & $0.003(0.002)$ \\
\hline Share of repeaters & $0.005^{* *}(0.002)$ \\
\hline Unexplained part & $-0.004(0.006)$ \\
\hline Observations (secondary school) & 280 \\
\hline Observations (middle school) & 298 \\
\hline Observations (total) & 578 \\
\hline
\end{tabular}

Source: Author's calculations.

Notes. $*, * *, * * *$ : the coefficient is statistically significant at $90 \%, 95 \%$ and $99 \%$ confidence levels respectively. Standard errors are in parentheses.

\section{Chart A1}

Distribution of schools by average exam scores (2015)

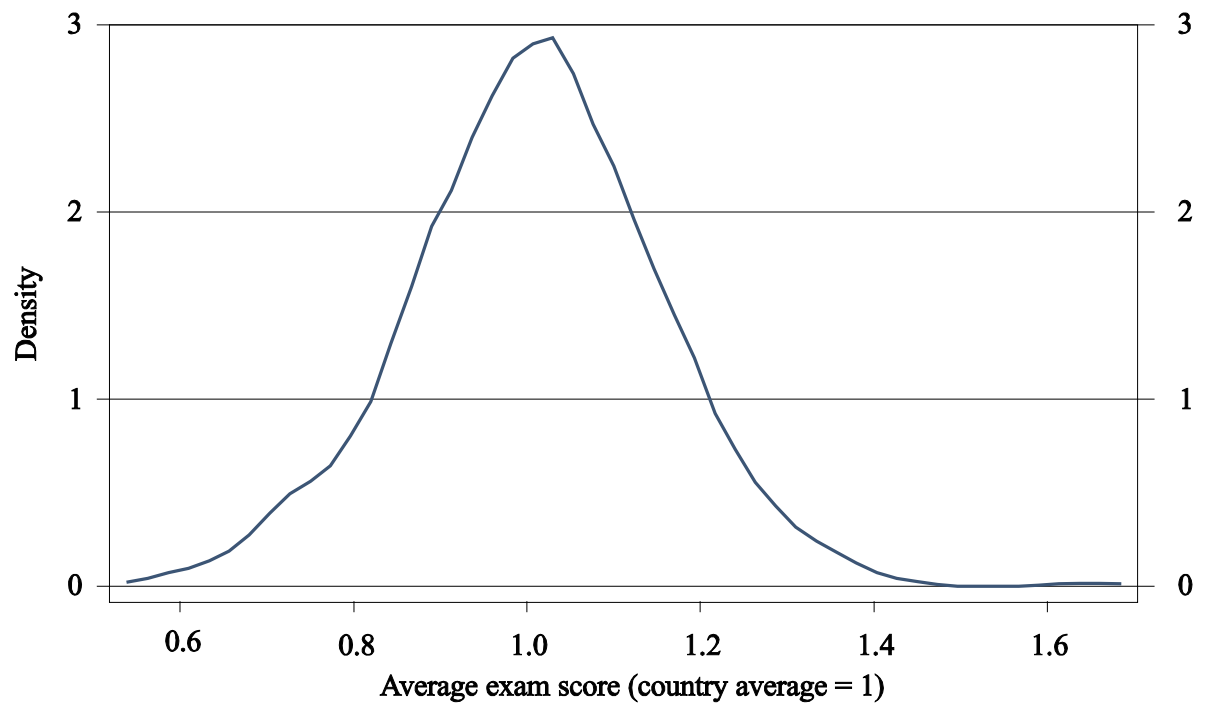

Sources: Ministry of Education and Science data and the author's calculations. 


\section{Chart A2}

Distribution of schools by average exam scores according to school types (the Latvian language of instruction; 2015)

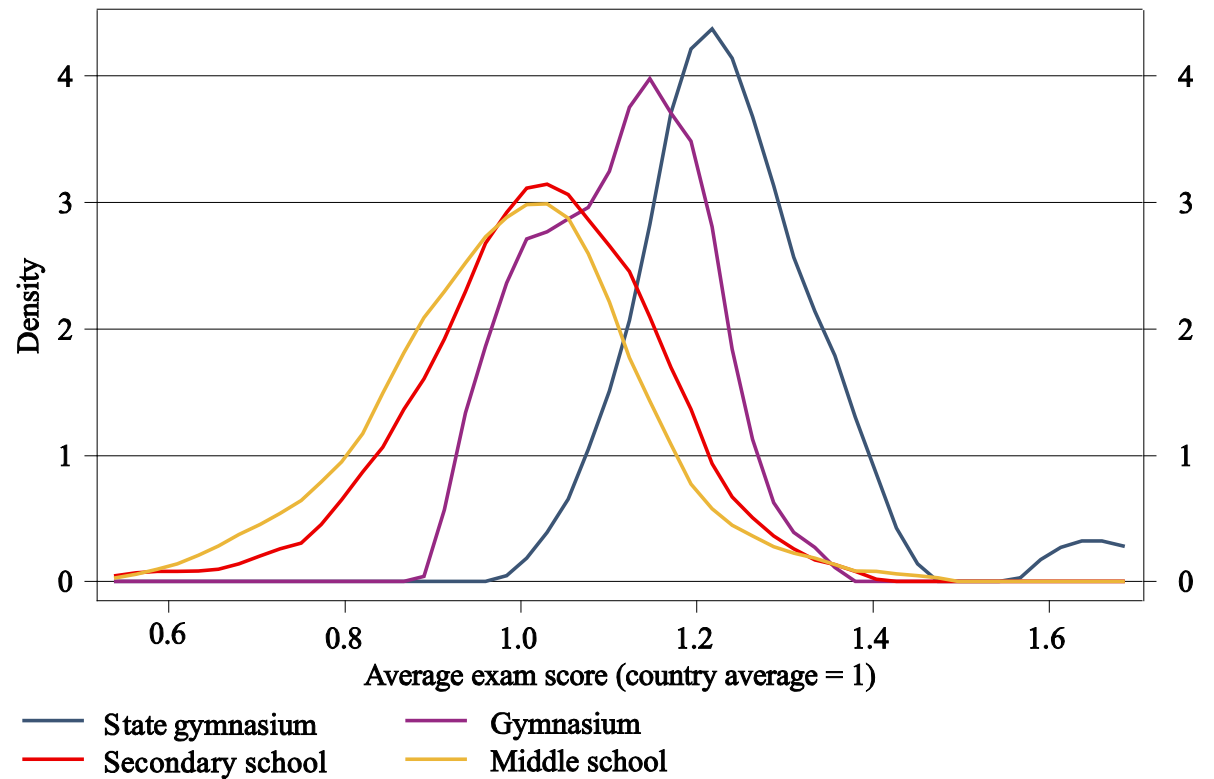

Sources: Ministry of Education and Science data and the author's calculations.

Chart A3

Distribution of schools by average exam scores according to school ownership (Latvian language of instruction; 2015)

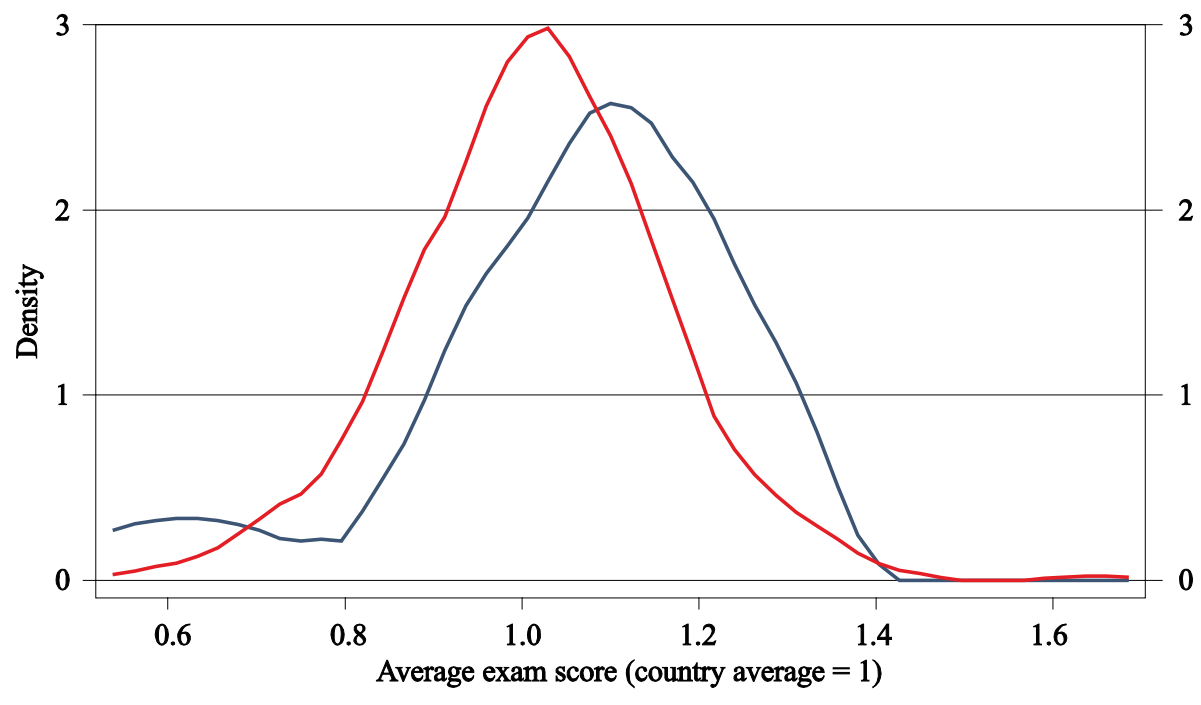

Private $\quad$ Public

Sources: Ministry of Education and Science data and the author's calculations. 


\section{Chart A4}

Distribution of schools by average exam scores according to school location (the Latvian language of instruction; 2015)

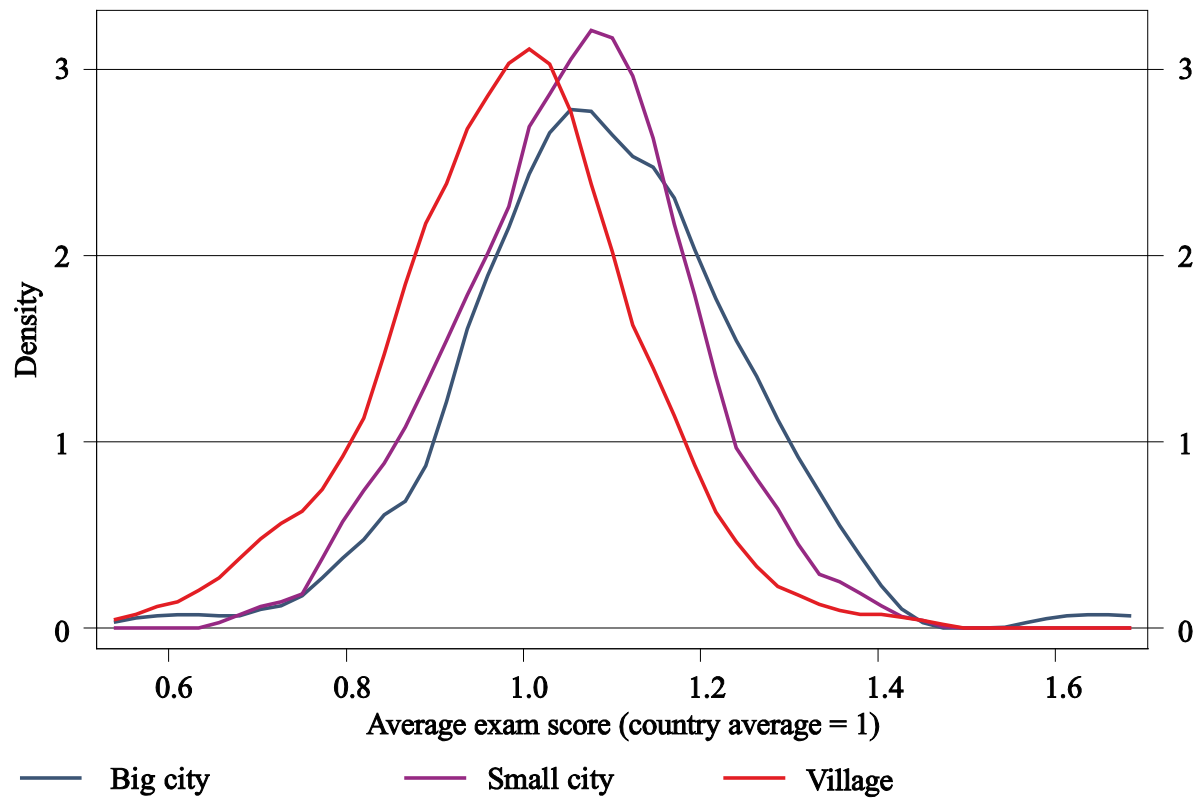

Sources: Ministry of Education and Science data and the author's calculations.

Chart A5

Distribution of schools by average exam scores according to NUTS 3 regions (2015)

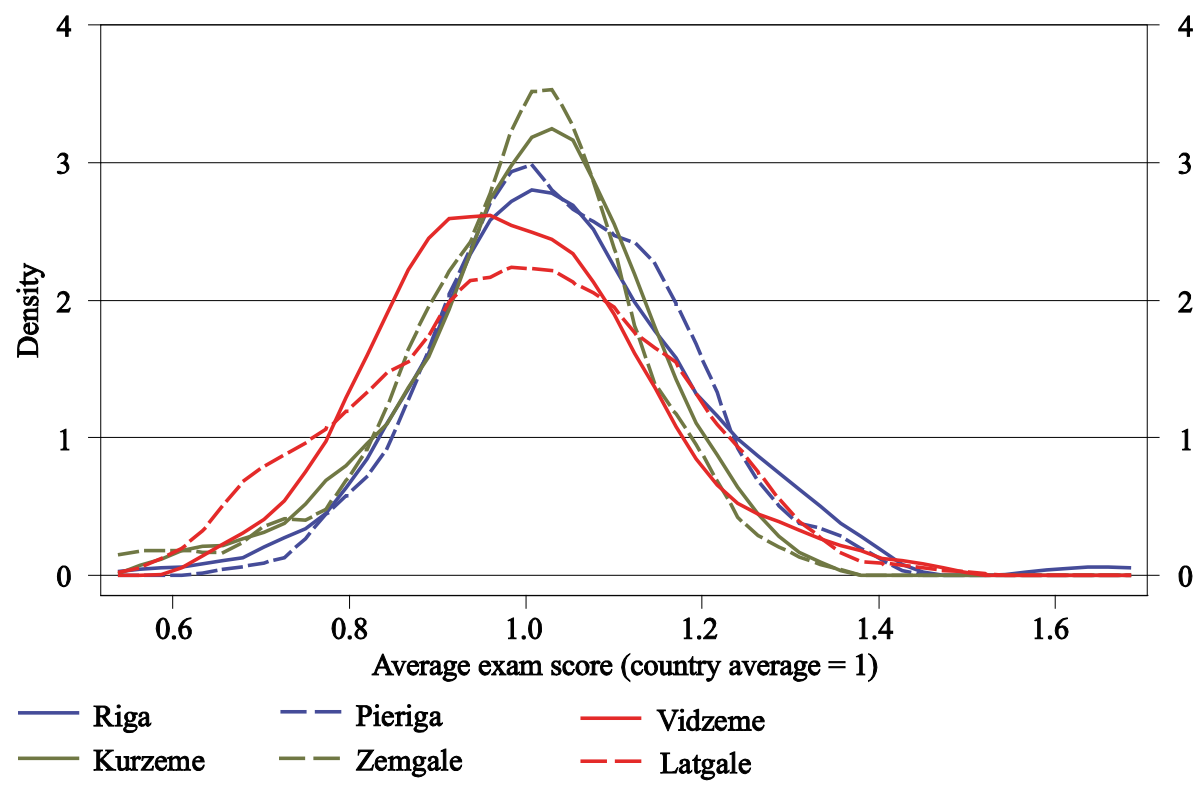

Sources: Ministry of Education and Science data and the author's calculations. 


\section{Chart A6}

Distribution of schools by average exam scores in Grade 12 according to the language of instruction in a school (2015)

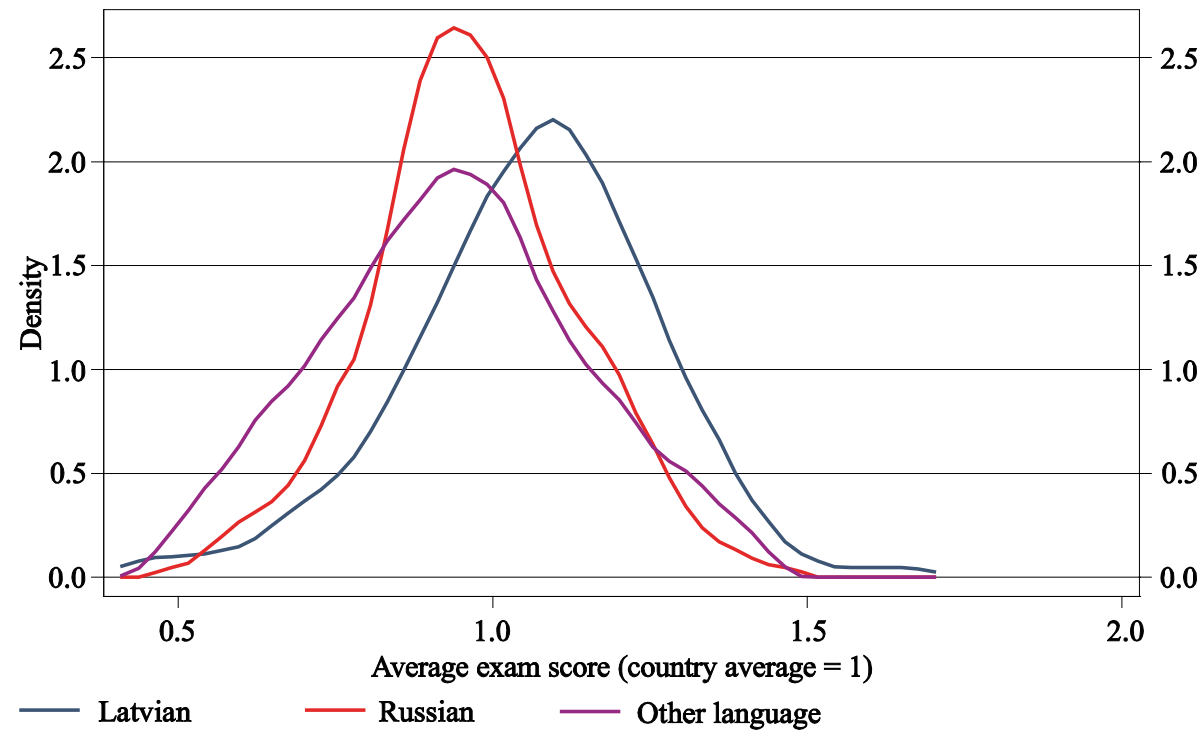

Sources: Ministry of Education and Science data and the author's calculations.

Chart A7

Distribution of schools by average Latvian exam scores in Grade 12 according to the language of instruction in a school (2015)

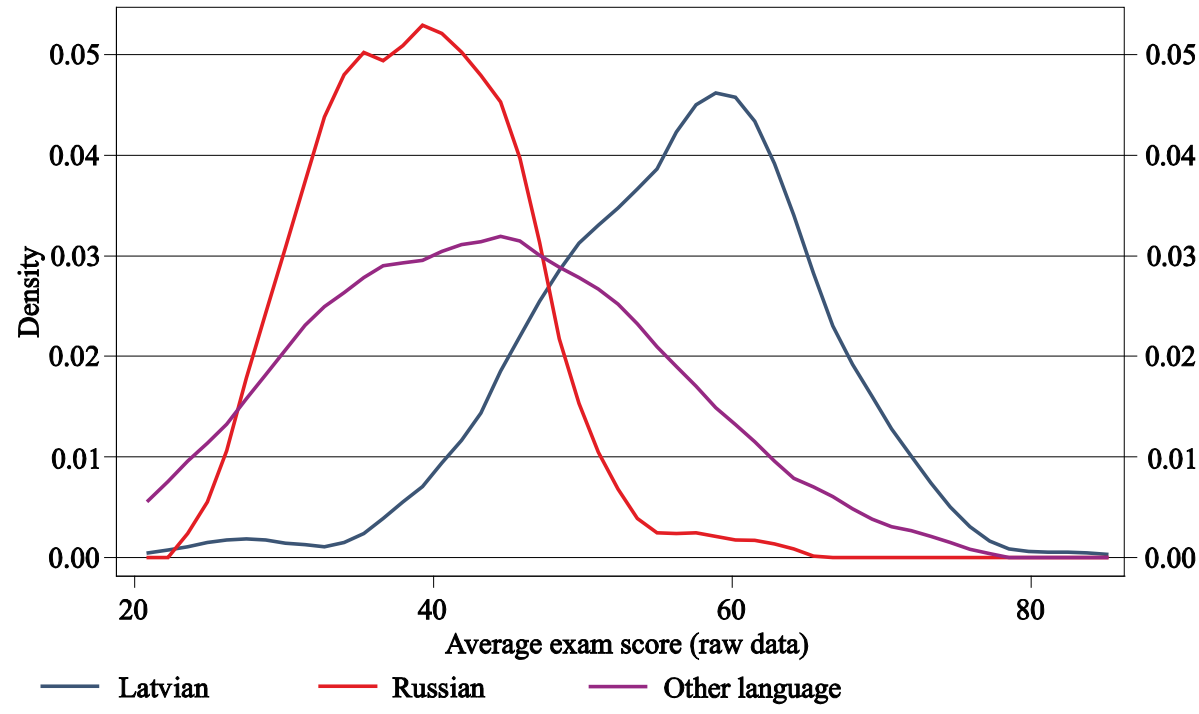

Sources: Ministry of Education and Science data and the author's calculations. 


\section{Chart A8}

Distribution of schools by average English exam scores in Grade 12 according to the language of instruction in a school (2015)

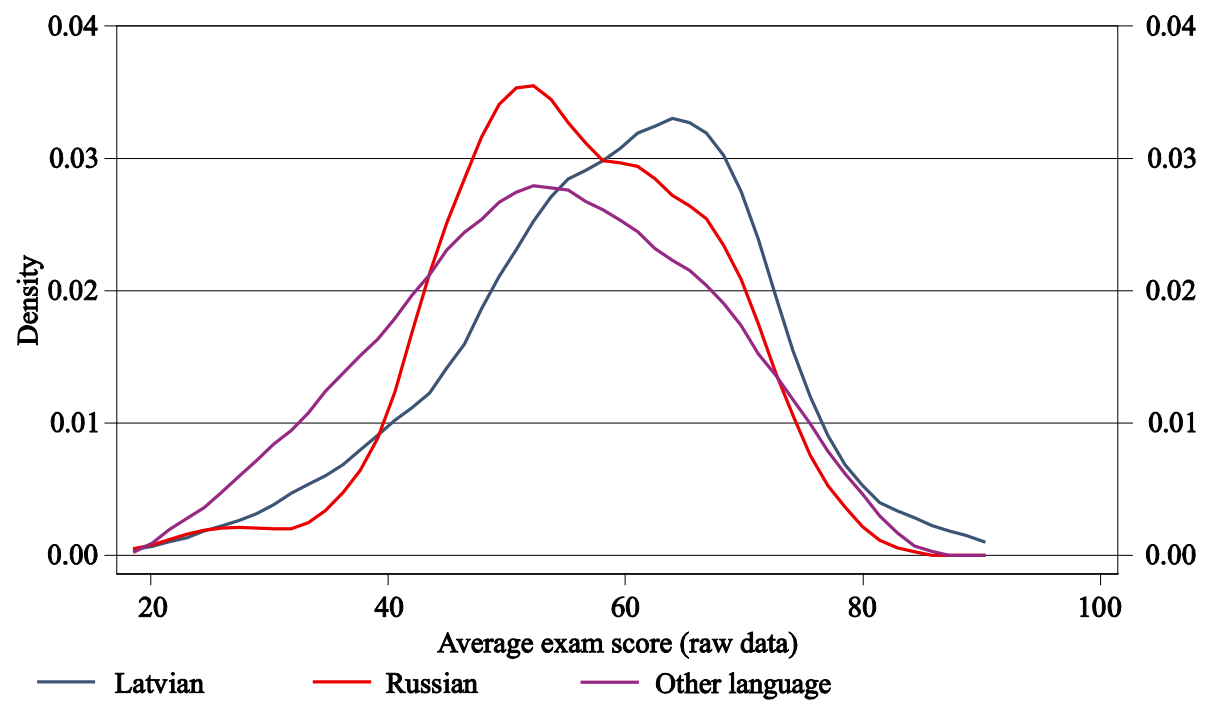

Sources: Ministry of Education and Science data and the author's calculations.

\section{Chart A9}

Distribution of schools by average mathematics exam scores in Grade 12 according to the language of instruction in a school (2015)

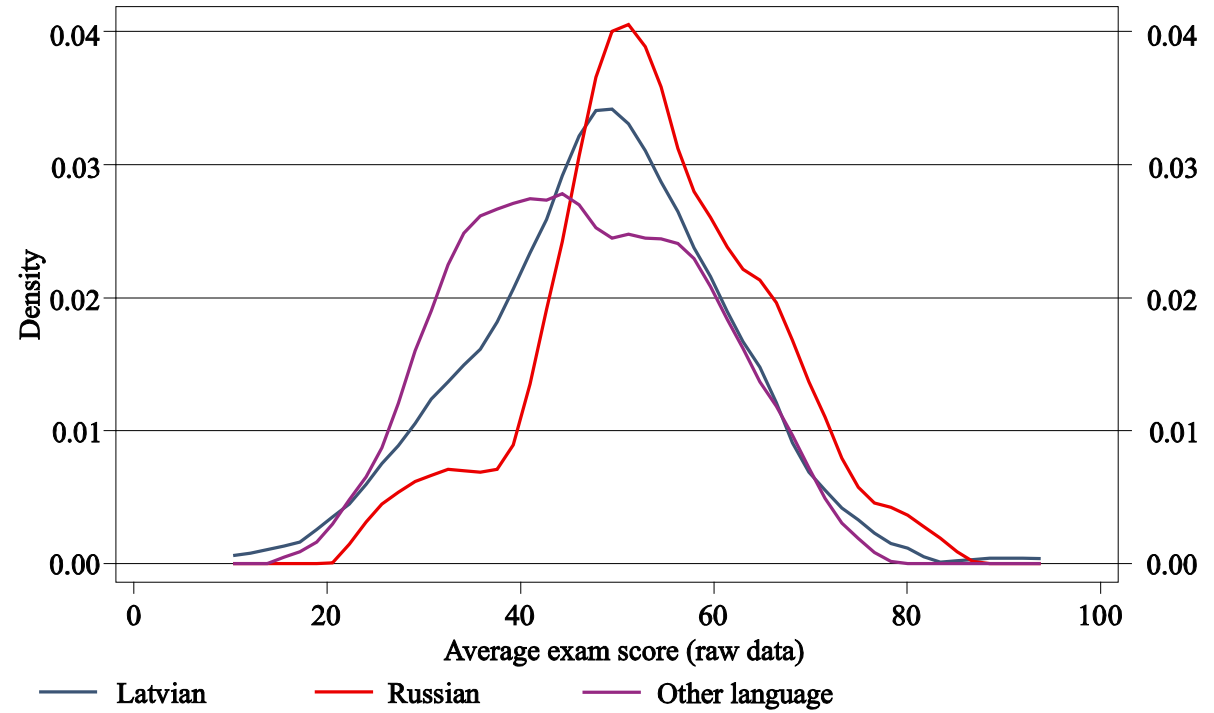

Sources: Ministry of Education and Science data and the author's calculations. 


\section{Chart A10}

Distribution of schools by average exam scores in Grades 9 and 12 (2015)

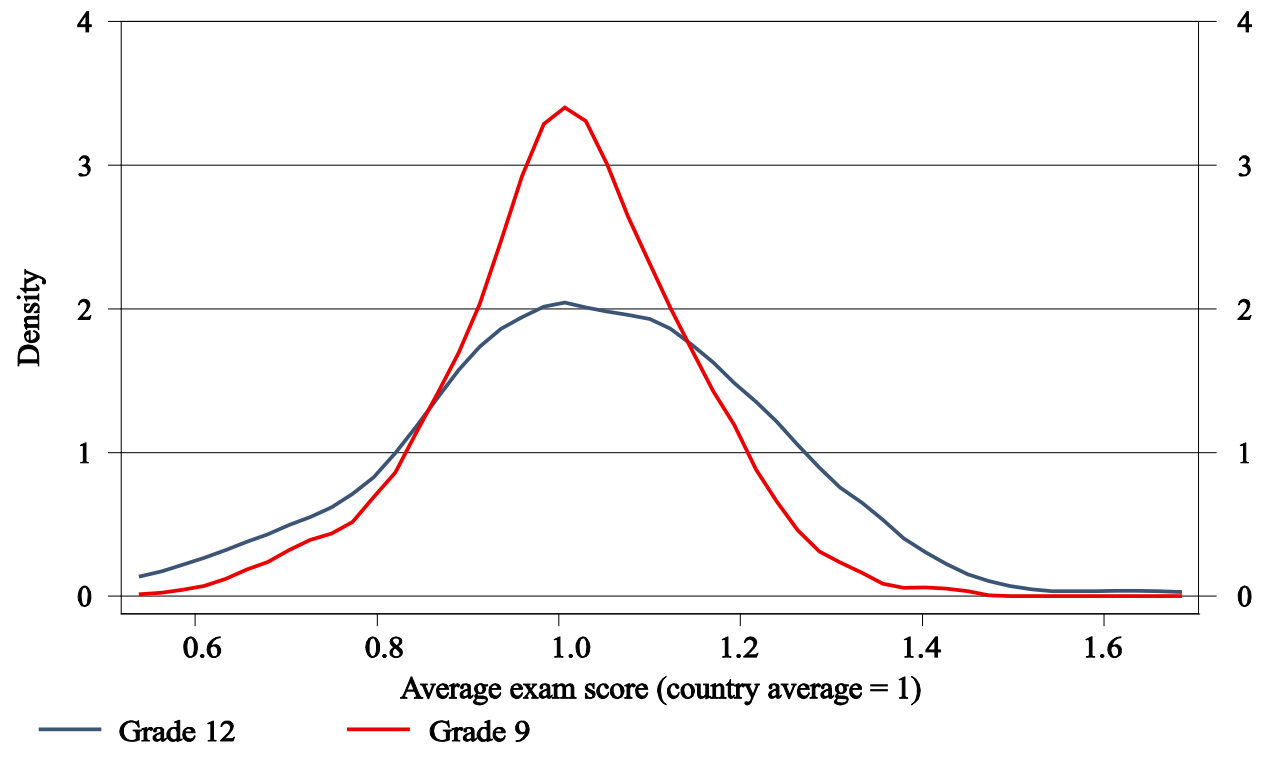

4

Sources: Ministry of Education and Science data and the author's calculations.

\section{Chart A11}

Distribution of schools by average exam scores in Grade 12 by subject (2015)

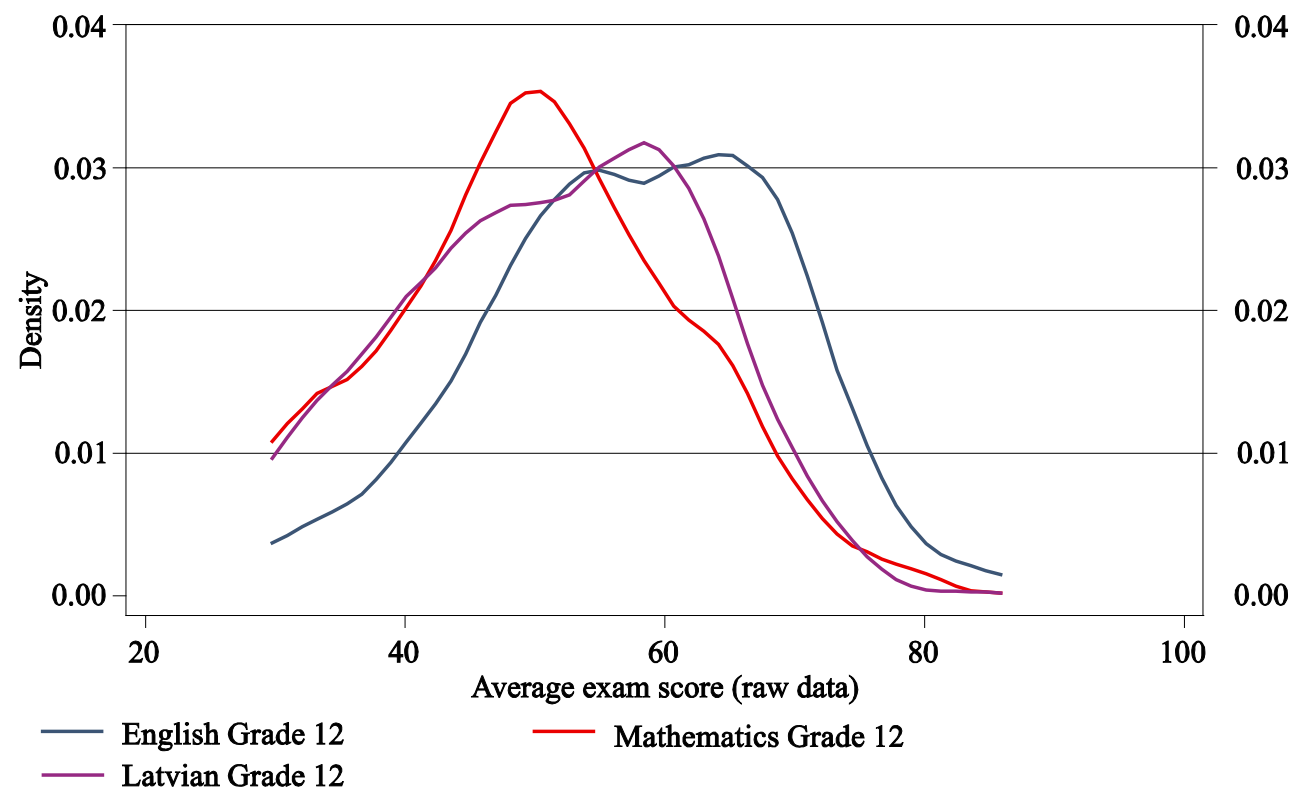

Sources: Ministry of Education and Science data and the author's calculations. 
Chart A12

Distribution of schools by average exam scores in Grade 9 by subject (2015)

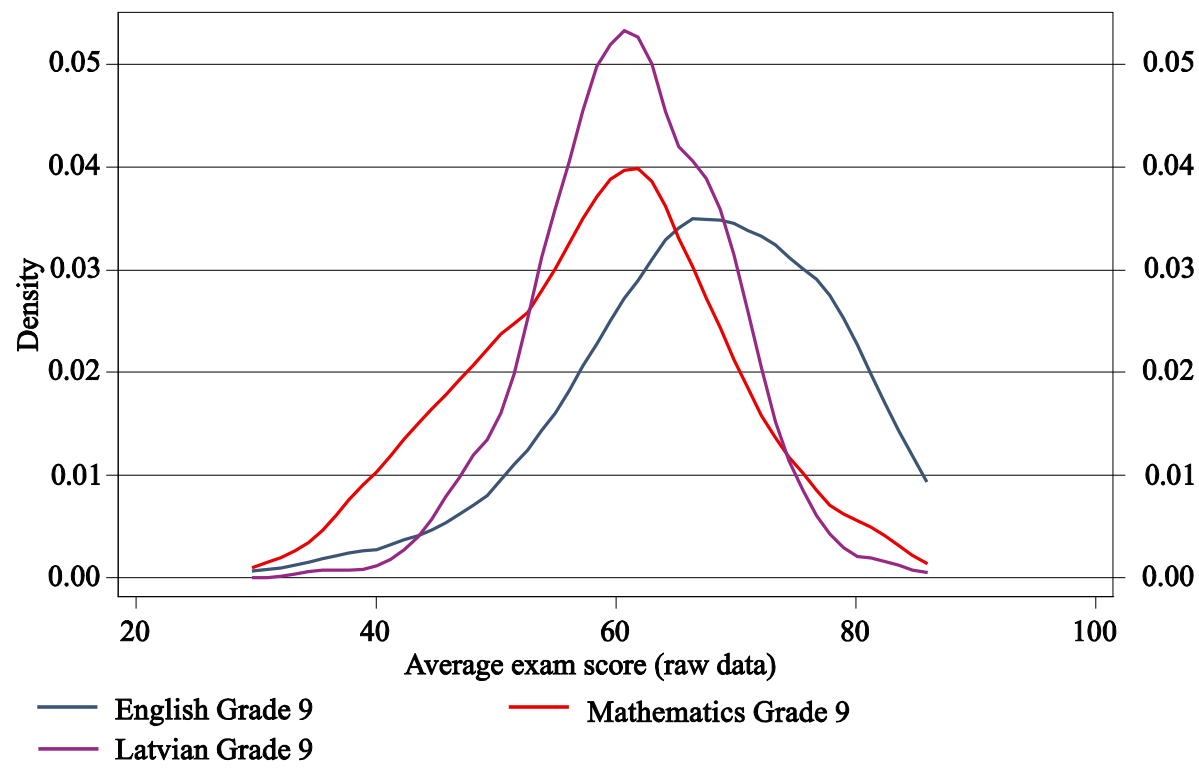

Sources: Ministry of Education and Science data and the author's calculations.

Chart A13

Distribution of schools by average exam scores according to school size (2015)

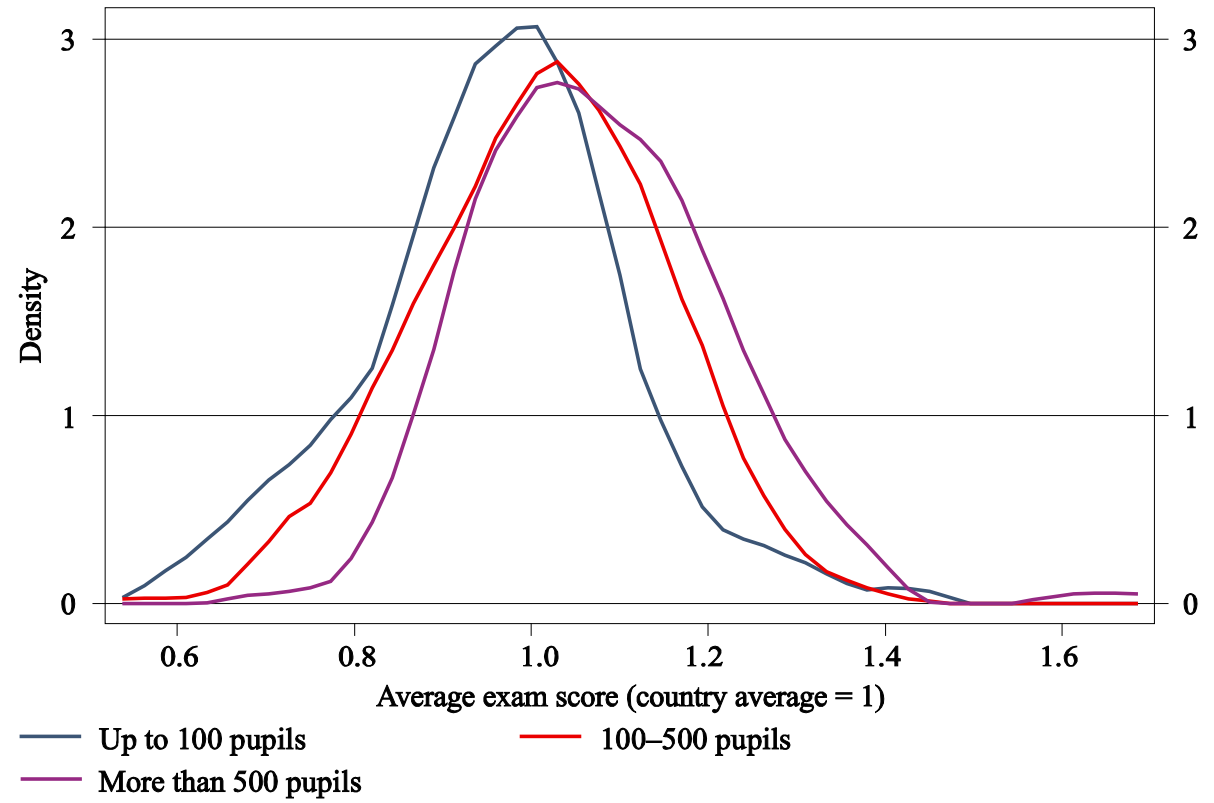

Sources: Ministry of Education and Science data and the author's calculations. 


\section{Chart A14}

Distribution of schools by the number of pupils (September 2014)

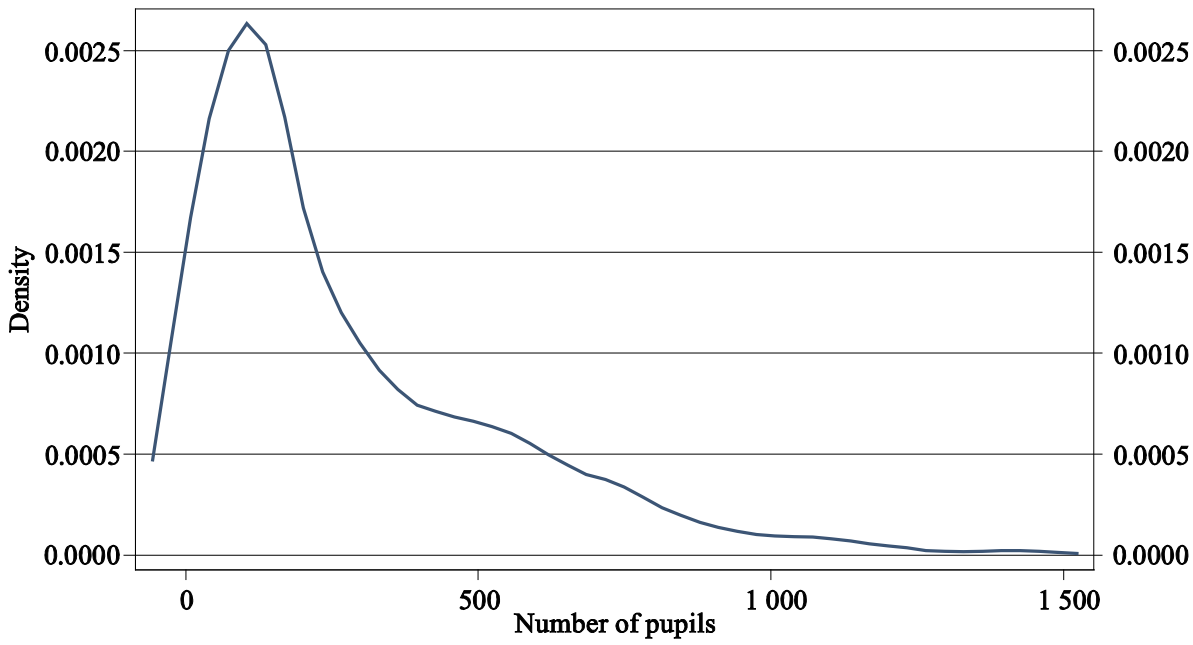

Sources: Ministry of Education and Science data and the author's calculations.

Chart A15

Distribution of schools by the number of pupils according to school type (September 2014)

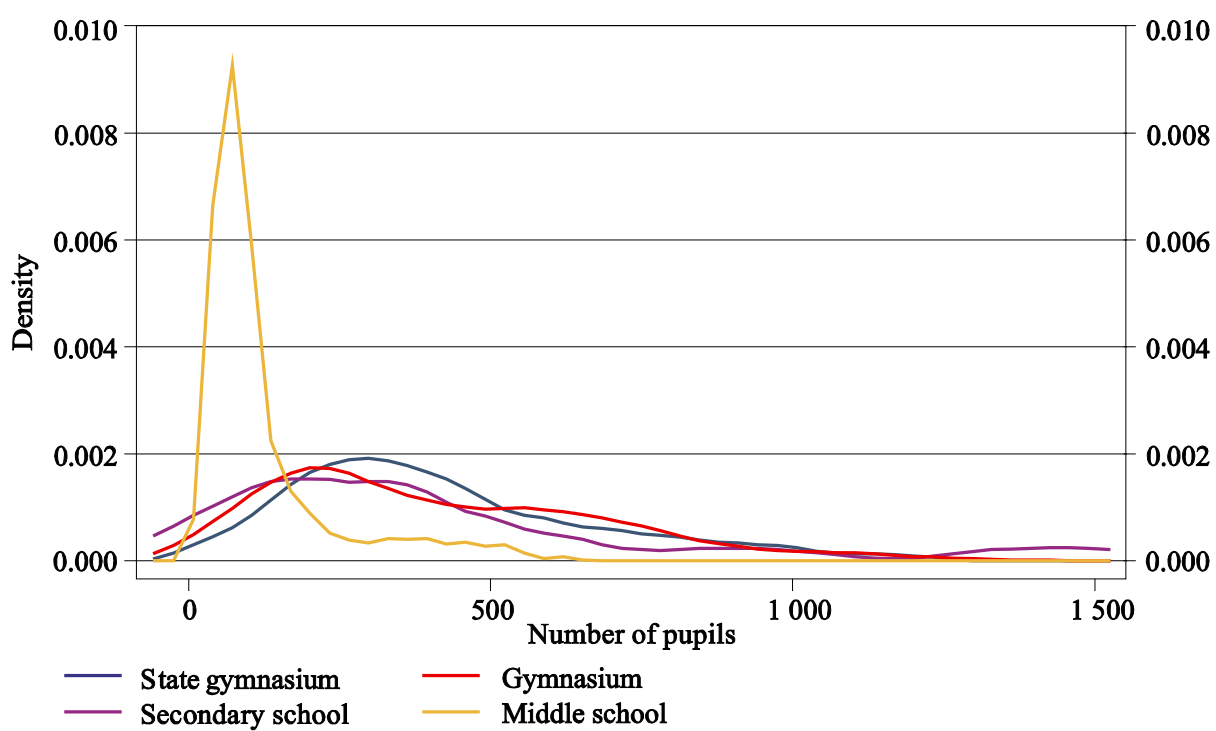

Sources: Ministry of Education and Science data and the author's calculations. 


\section{Chart A16}

Distribution of schools by teachers' average gross monthly salary (euro; January 2015)

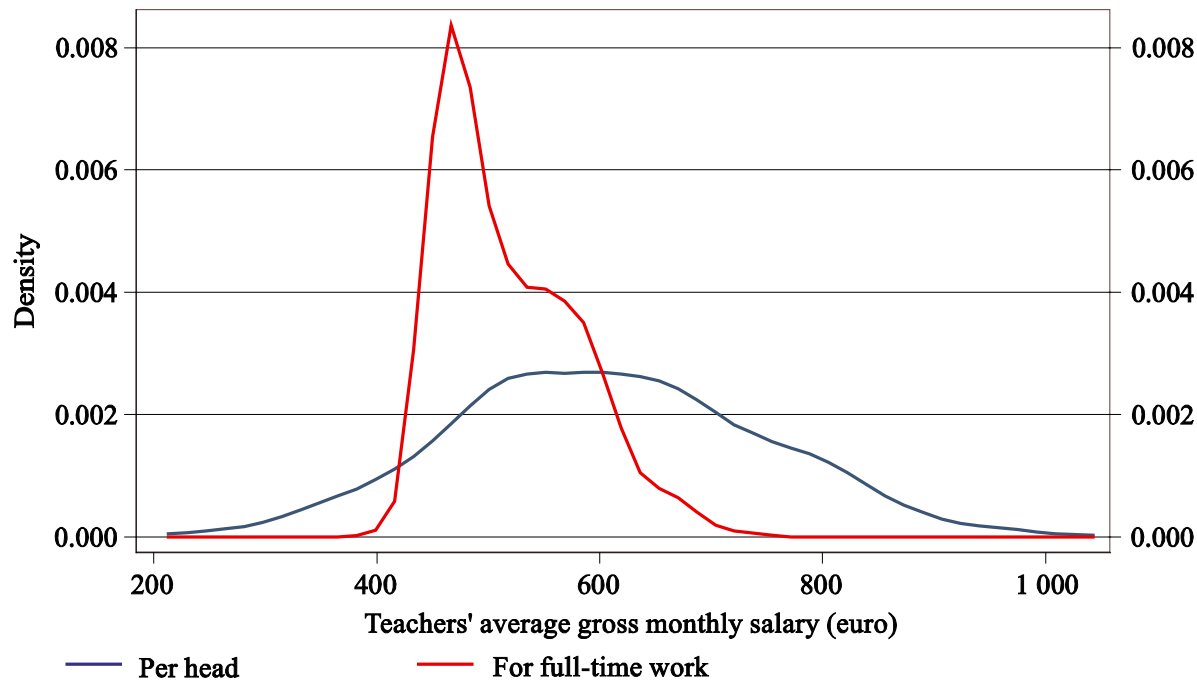

Sources: Ministry of Education and Science data and the author's calculations.

Chart A17

Distribution of schools by teachers' average workload (January 2015)

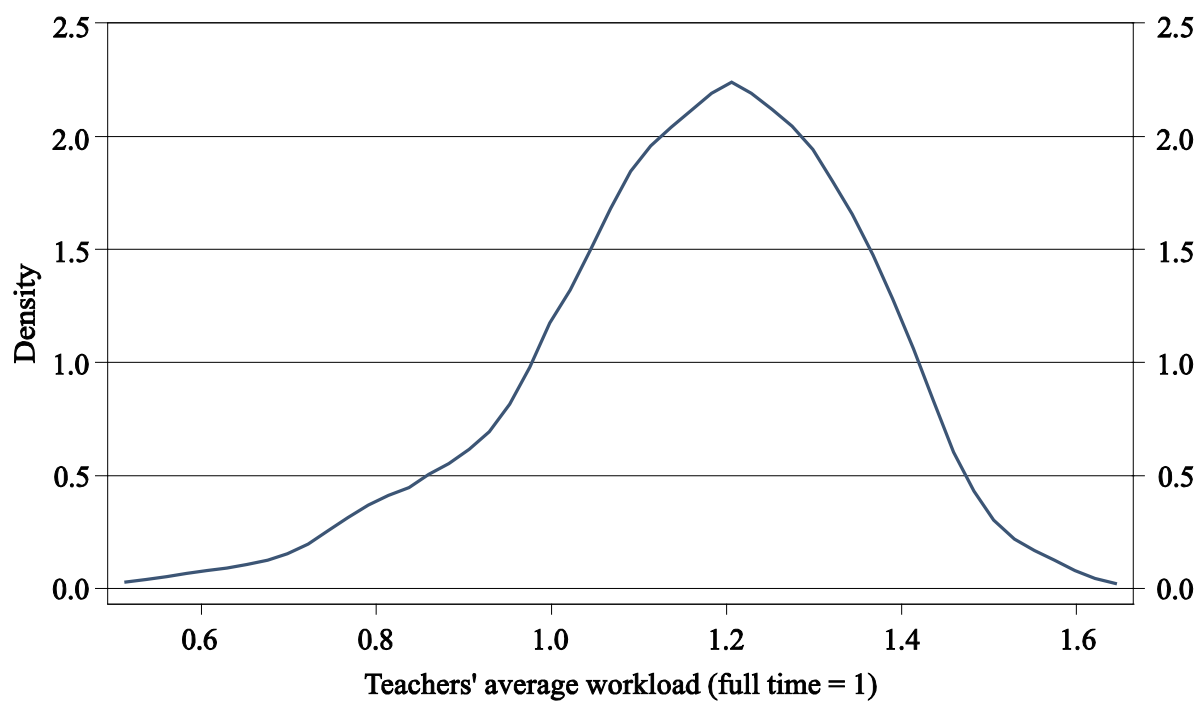

Sources: Ministry of Education and Science data and the author's calculations. 
Chart A18

Association between the teachers' average gross salary and exam scores

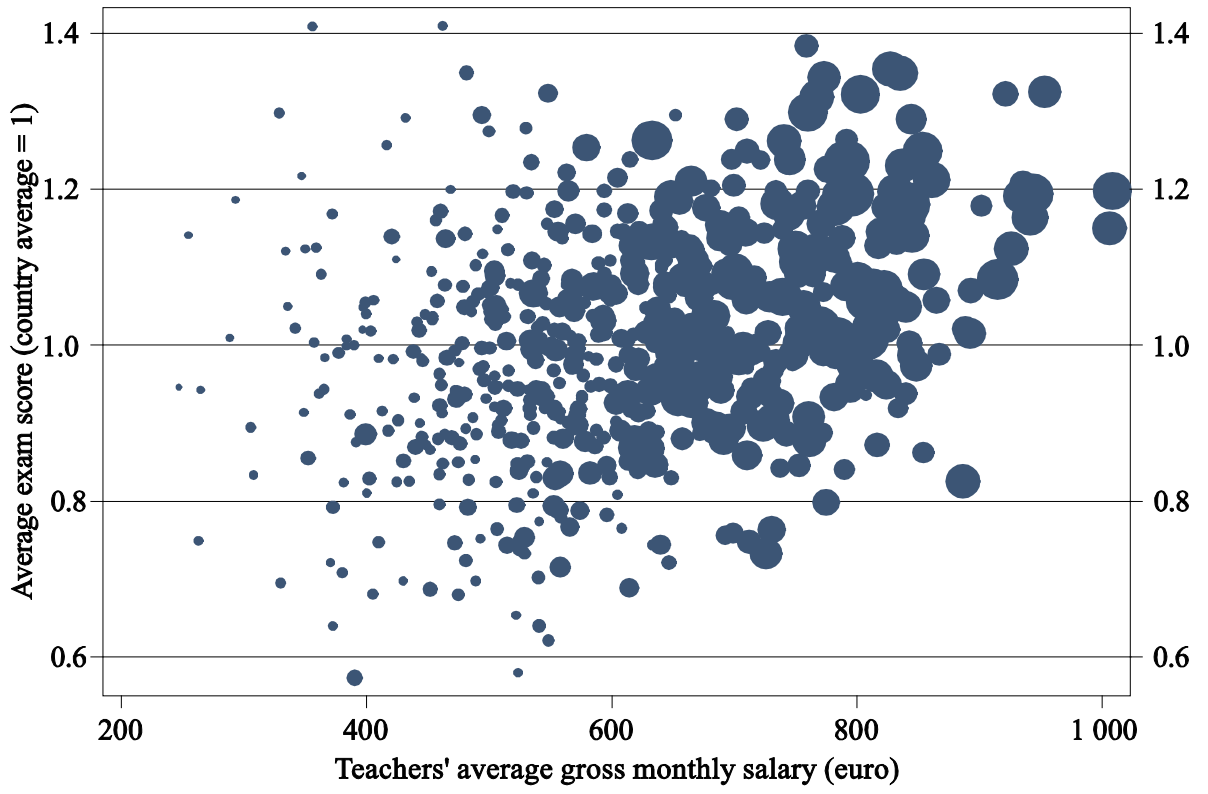

Sources: Ministry of Education and Science data and the author's calculations.

Chart A19

Distribution of schools by teachers' average gross monthly salary according to the number of pupils in a school (euro; January 2015)

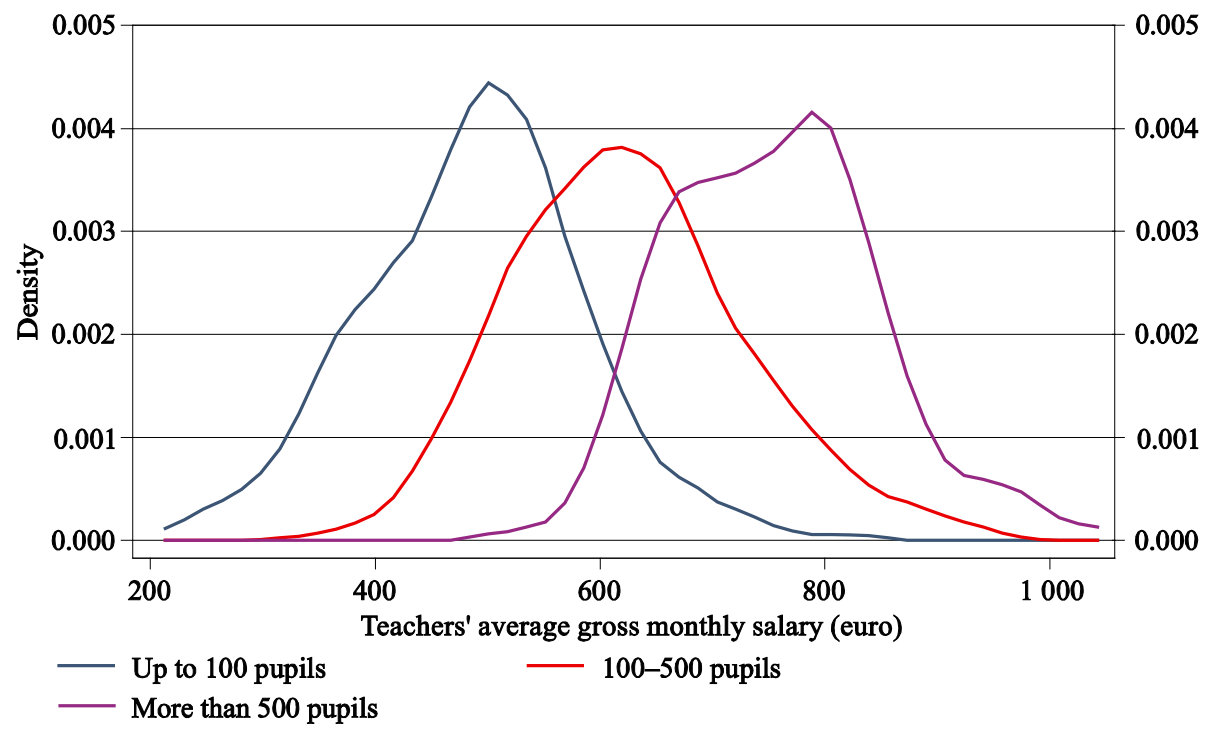

Sources: Ministry of Education and Science data and the author's calculations. 


\section{Chart A20}

Distribution of schools by teachers' average gross monthly salary for full-time work according to the number of pupils in a school (euro; January 2015)

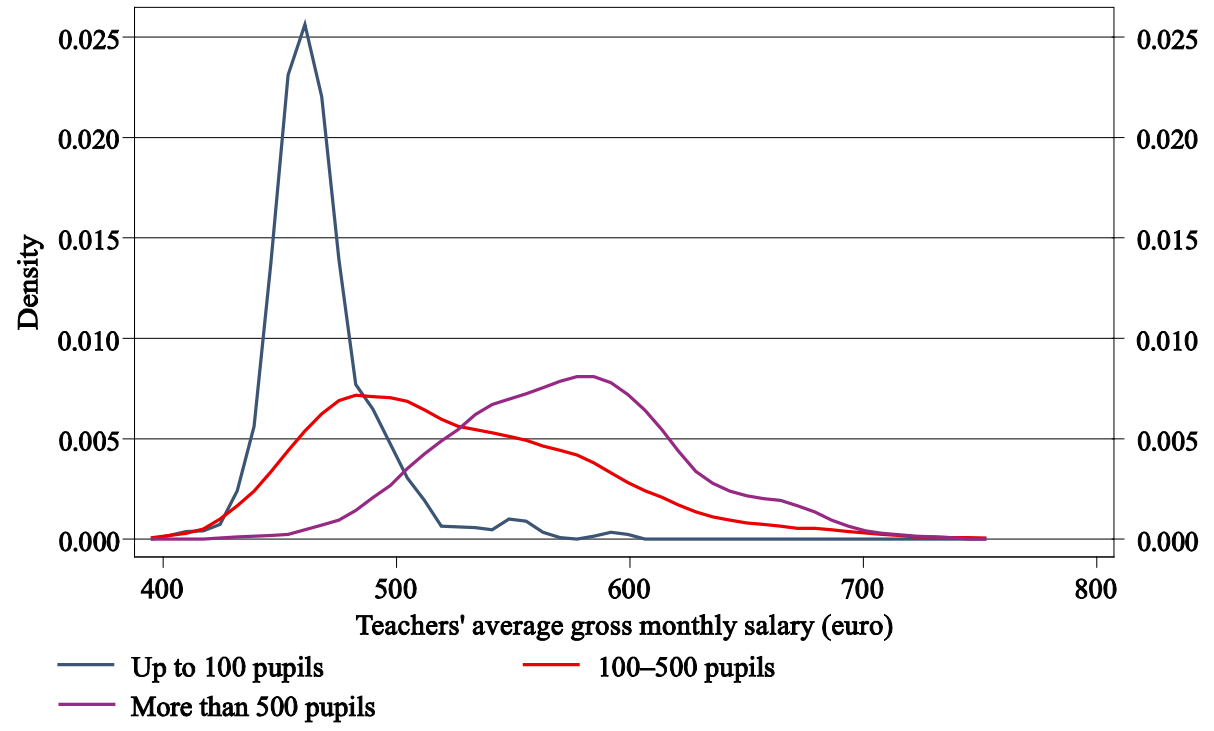

Sources: Ministry of Education and Science data and the author's calculations.

Chart A21

Distribution of schools by teachers' average workload according to the number of pupils in a school (January 2015)

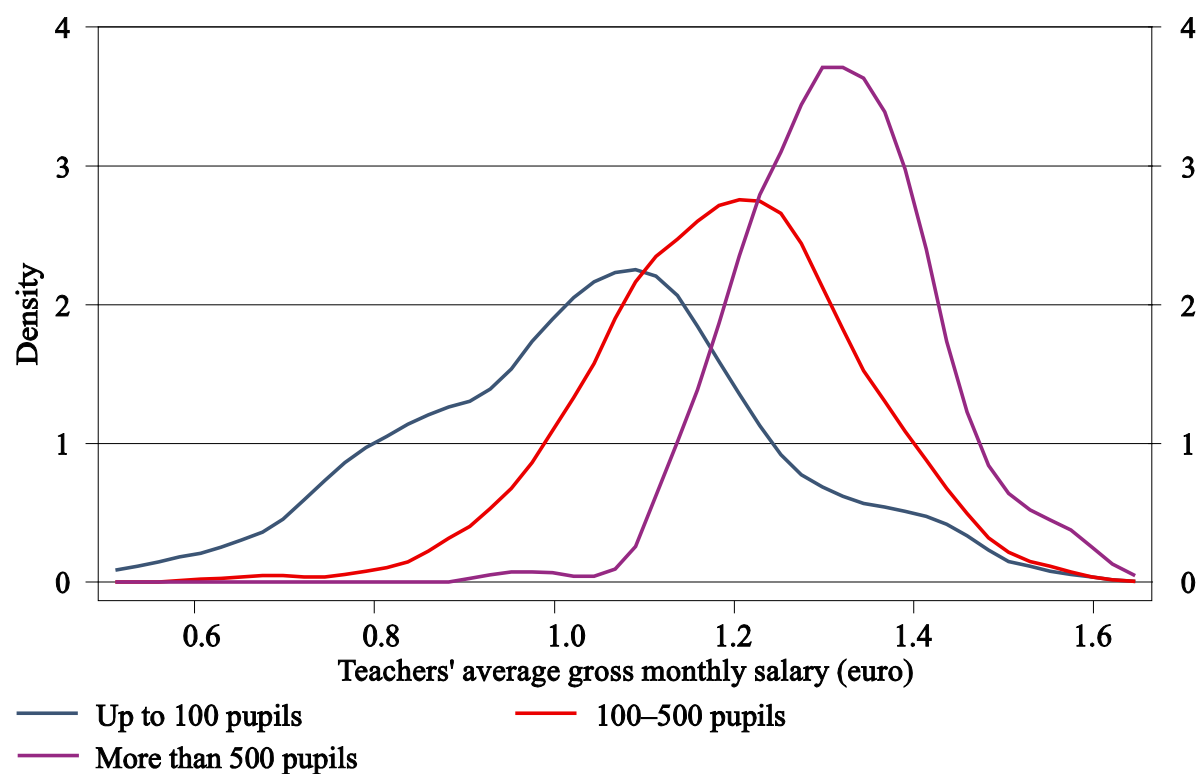

Sources: Ministry of Education and Science data and the author's calculations. 
Chart A22

Distribution of schools by teachers' average gross monthly salary according to school type (euro; January 2015)

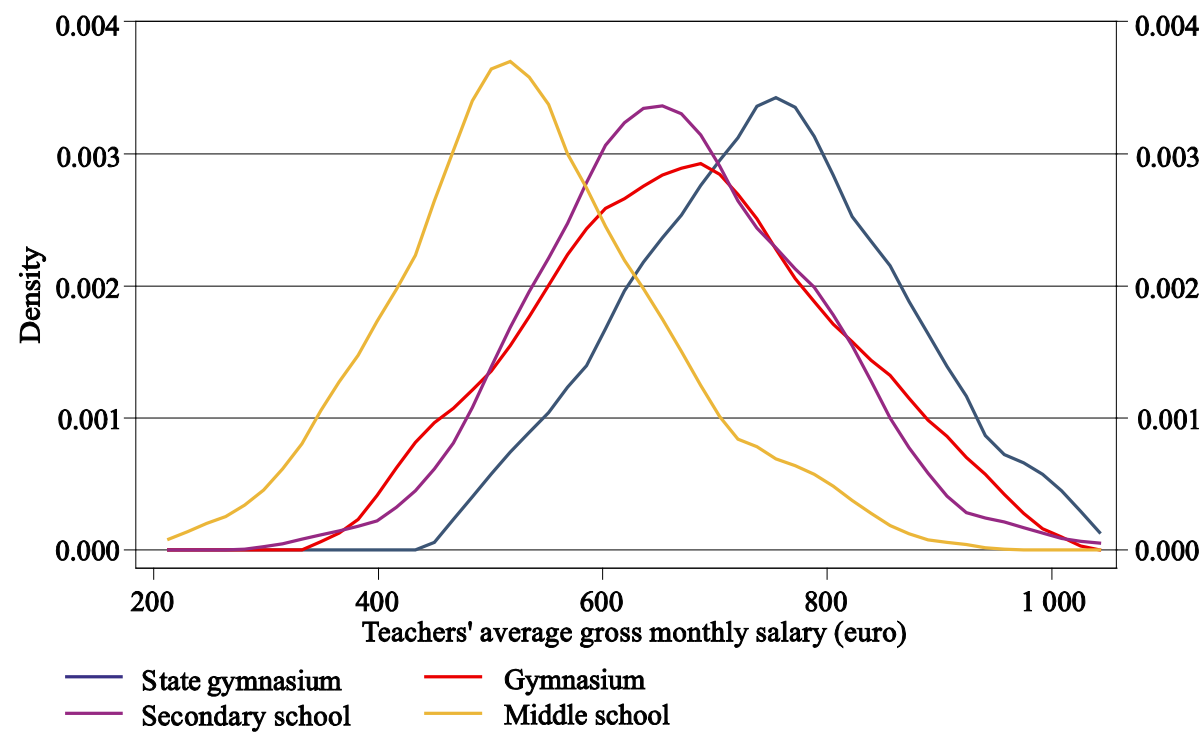

Sources: Ministry of Education and Science data and the author's calculations.

Chart A23

Distribution of schools by teachers' average gross monthly salary according to school location (euro; January 2015)

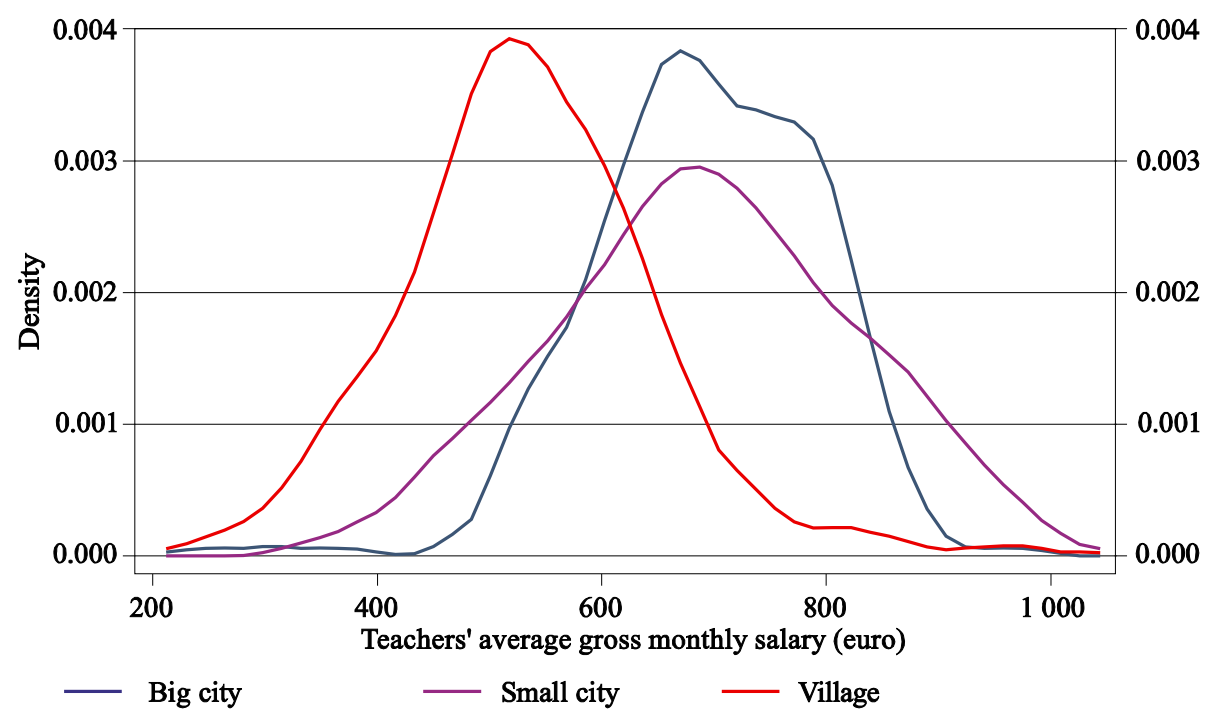

Sources: Ministry of Education and Science data and the author's calculations. 
Chart A24

Distribution of schools by teachers' average gross monthly salary according to the language of instruction in a school (euro; January 2015)

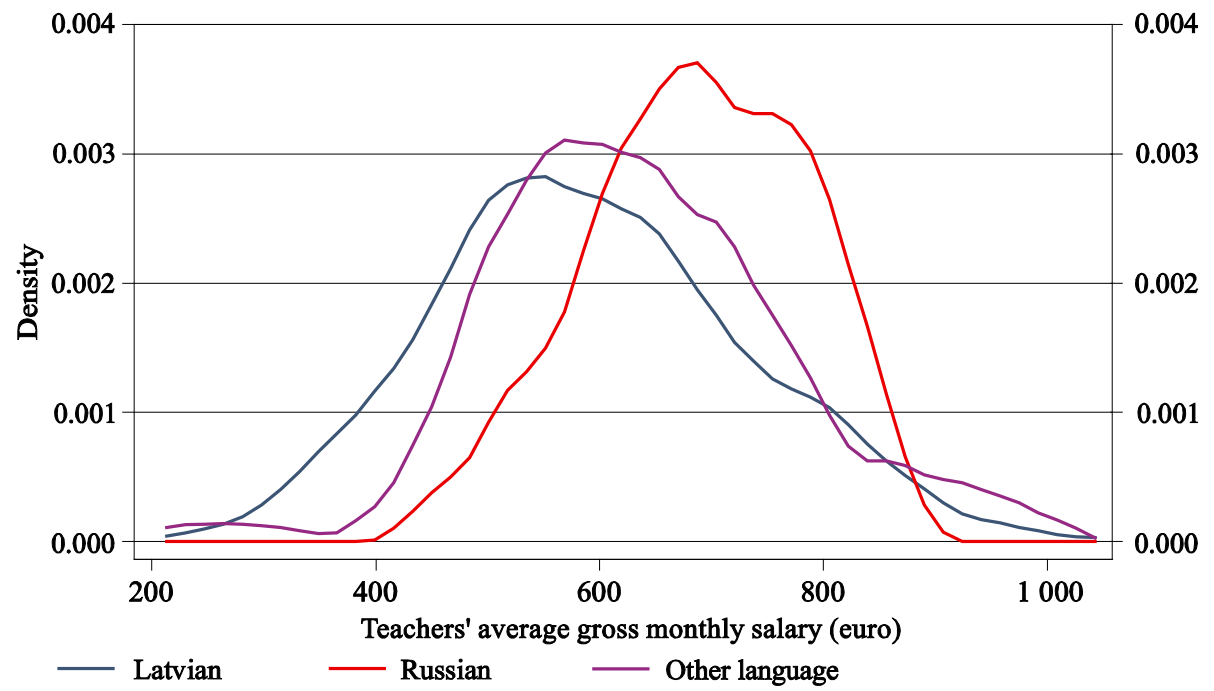

Sources: Ministry of Education and Science data and the author's calculations.

Chart A25

Association between the teacher age and exam scores (schools with more than 500 pupils)

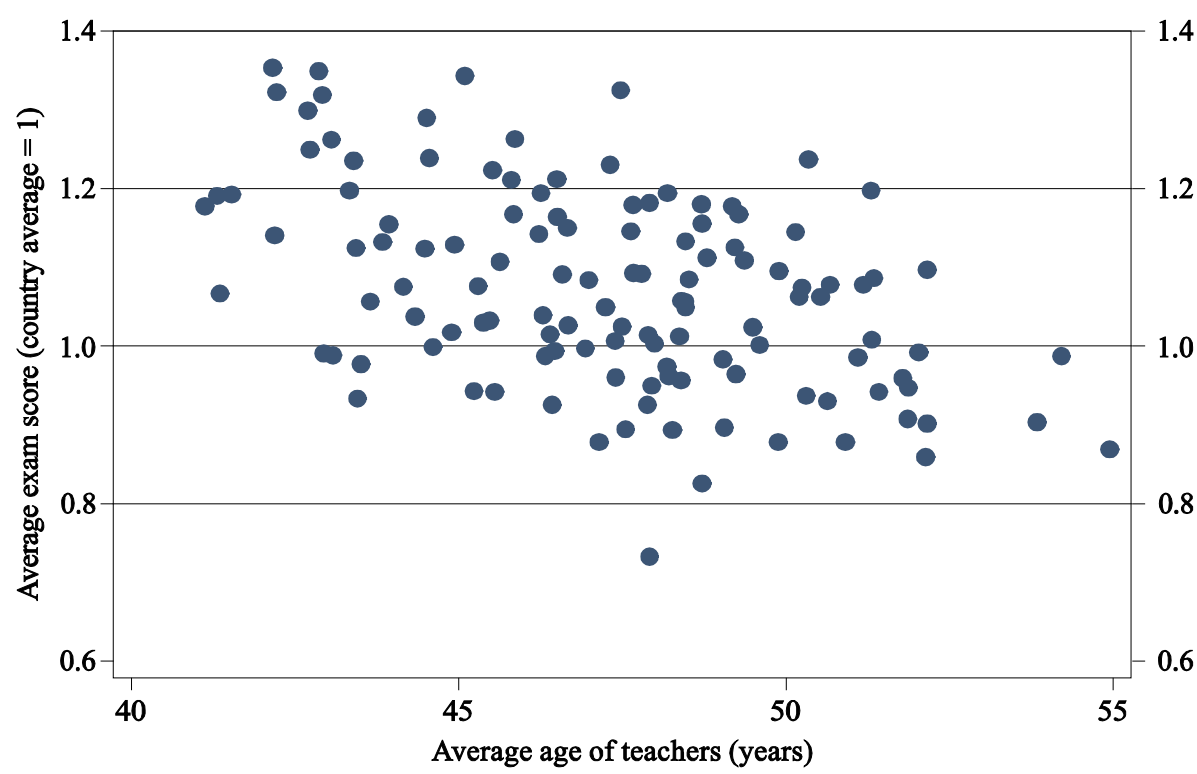

Sources: Ministry of Education and Science data and the author's calculations. 


\section{Chart A26}

Distribution of schools by teachers' average age (September 2014)

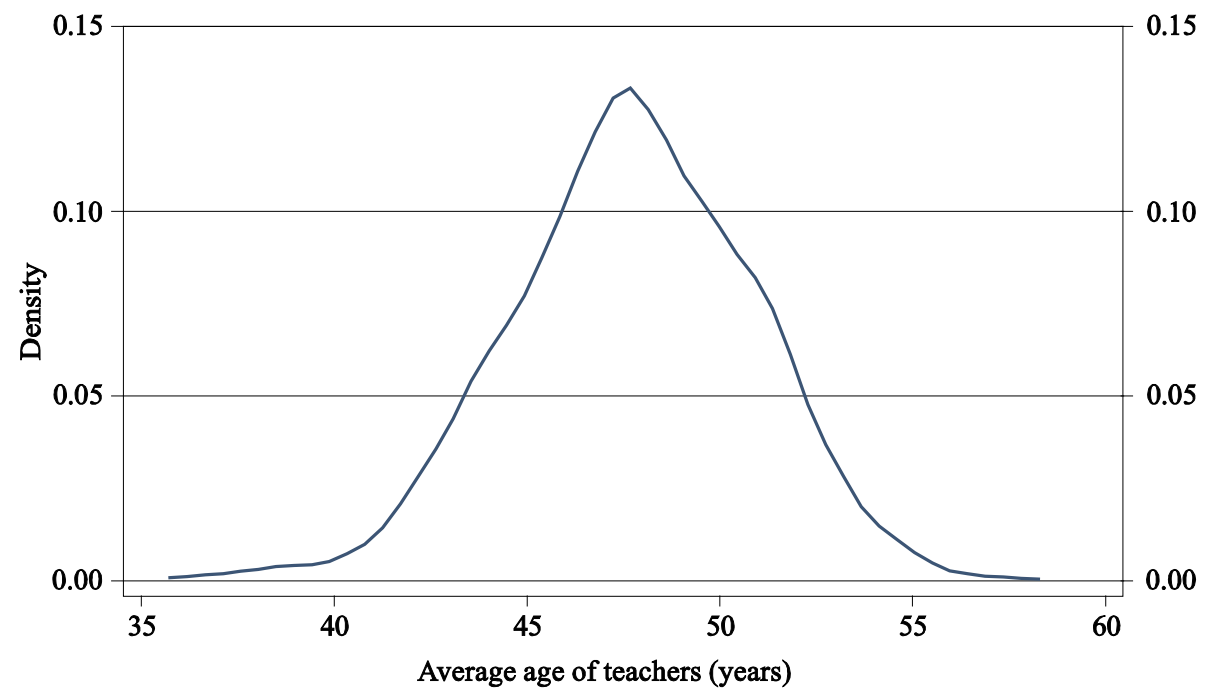

Sources: Ministry of Education and Science data and the author's calculations.

Chart A27

Average age of the employed by economic sector (years; 2014)

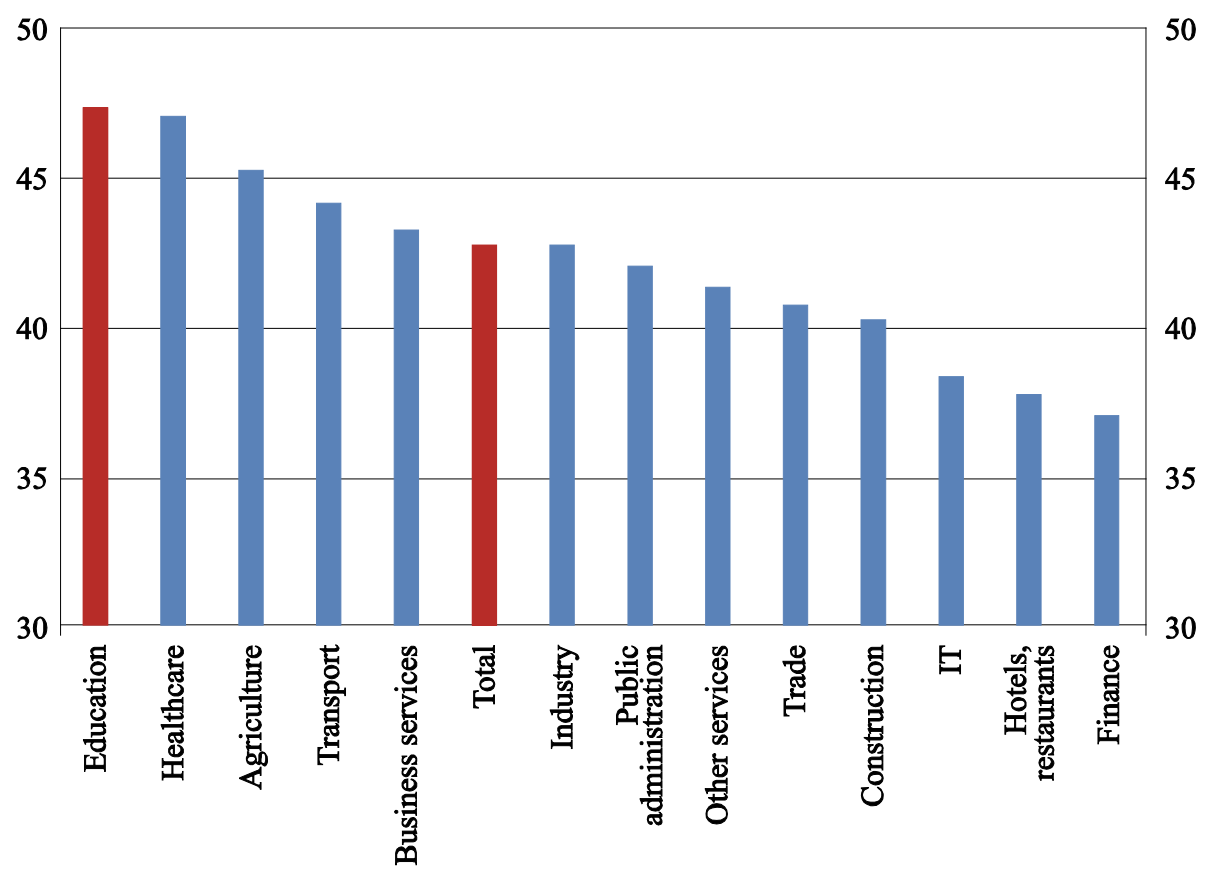

Sources: LFS micro data and the author's calculations. 
Chart A28

Share of employees under 40 years of age by economic sector (\% of all employees; 2014)

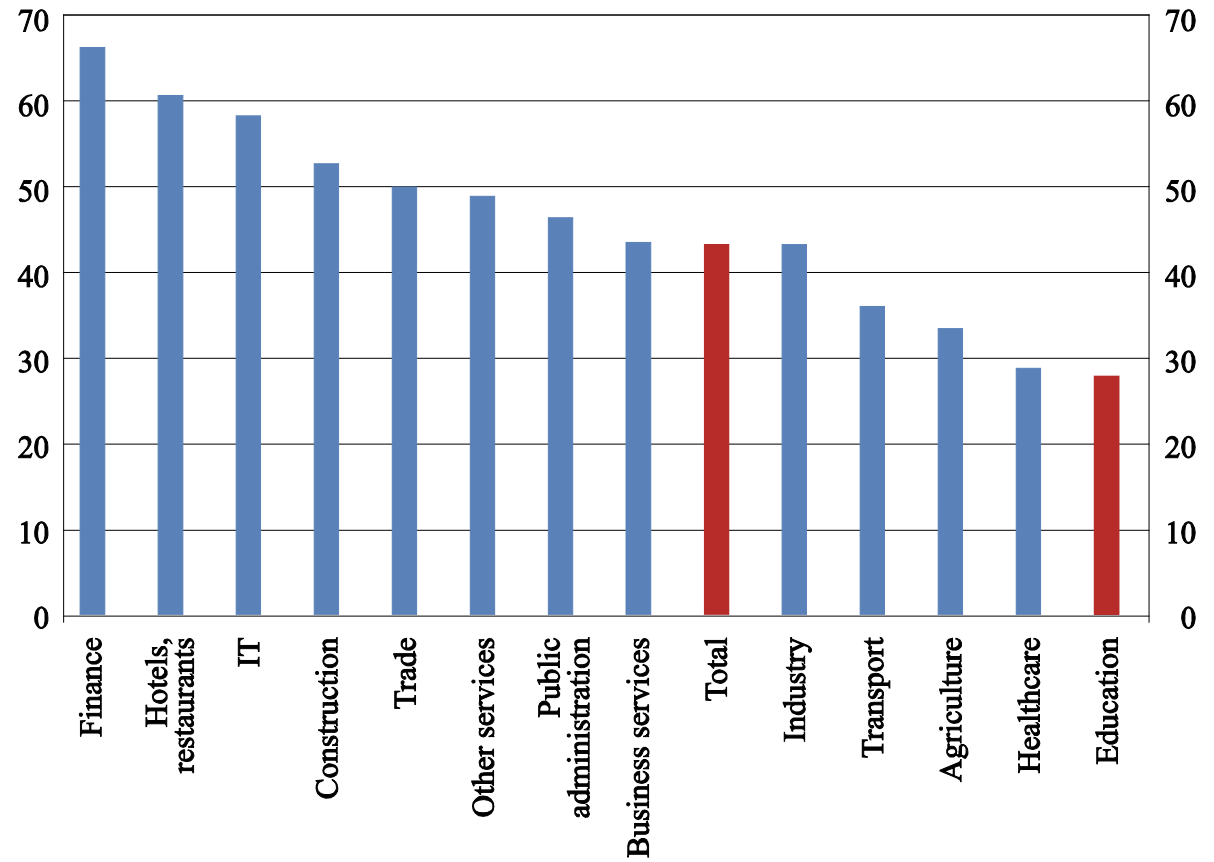

Source: Eurostat data.

Chart A29

Distribution of schools by teachers' average age according to the number of pupils in a school (September 2014)

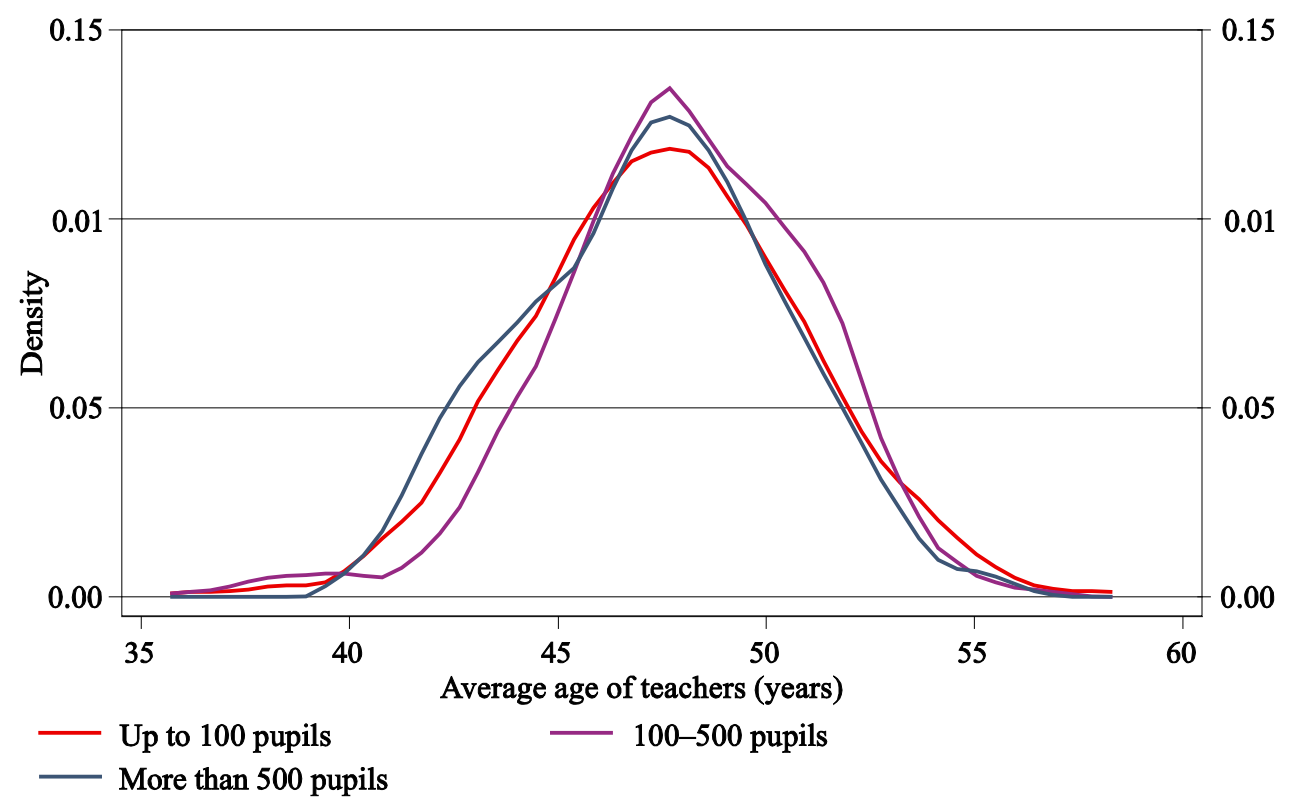

Sources: Ministry of Education and Science data and the author's calculations. 


\section{Chart A30}

Distribution of schools by teachers' average age according to school location (September 2014)

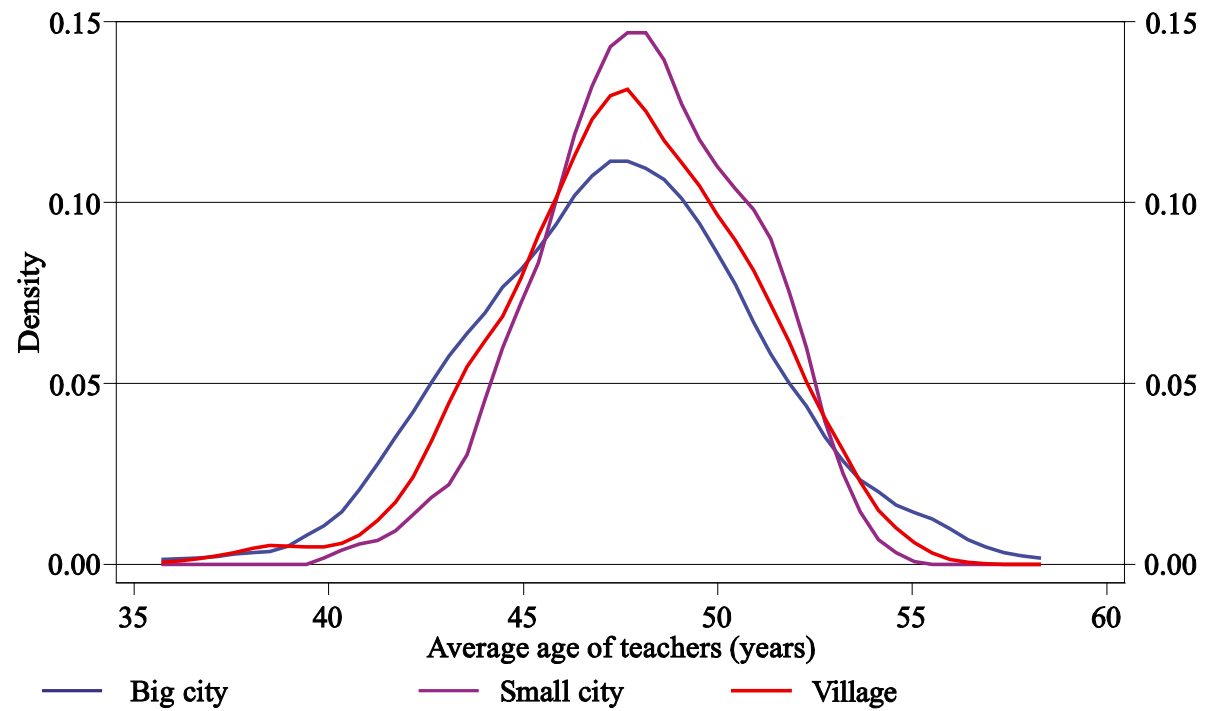

Sources: Ministry of Education and Science data and the author's calculations.

Chart A31

Distribution of schools by teachers' average age according to the language of instruction in a school (September 2014)

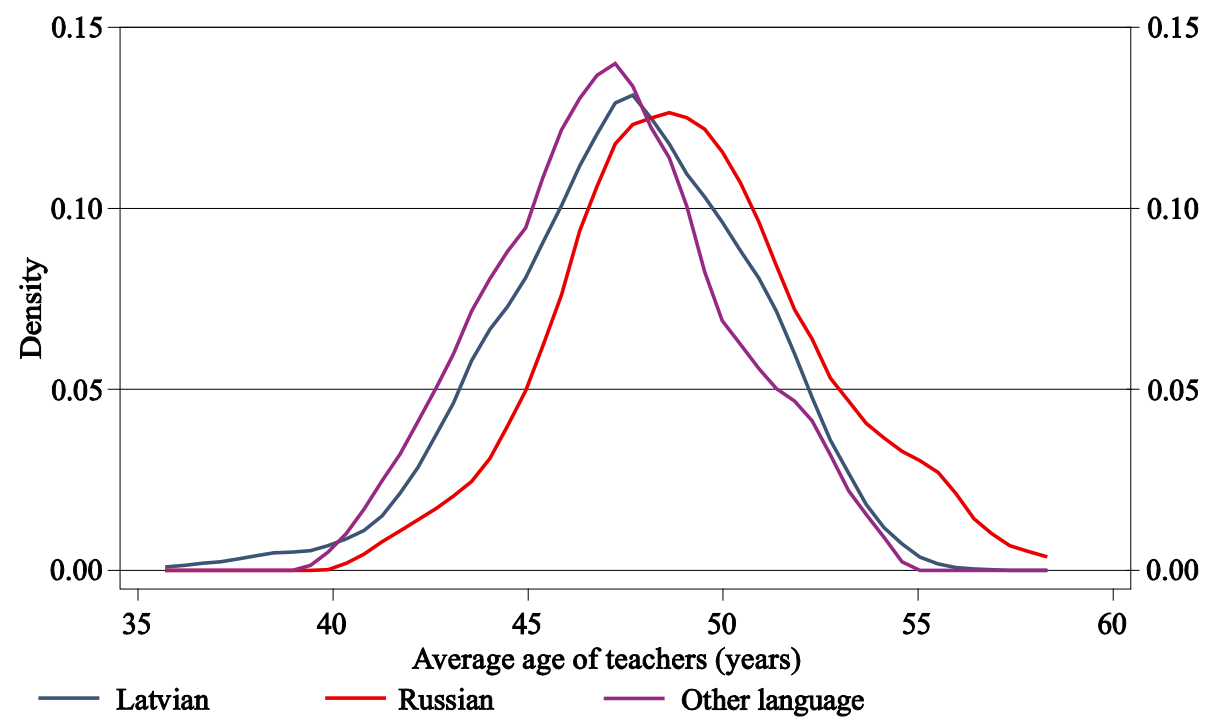

Sources: Ministry of Education and Science data and the author's calculations. 


\section{Chart A32}

Distribution of schools by teachers' average age according to school type (September 2014)

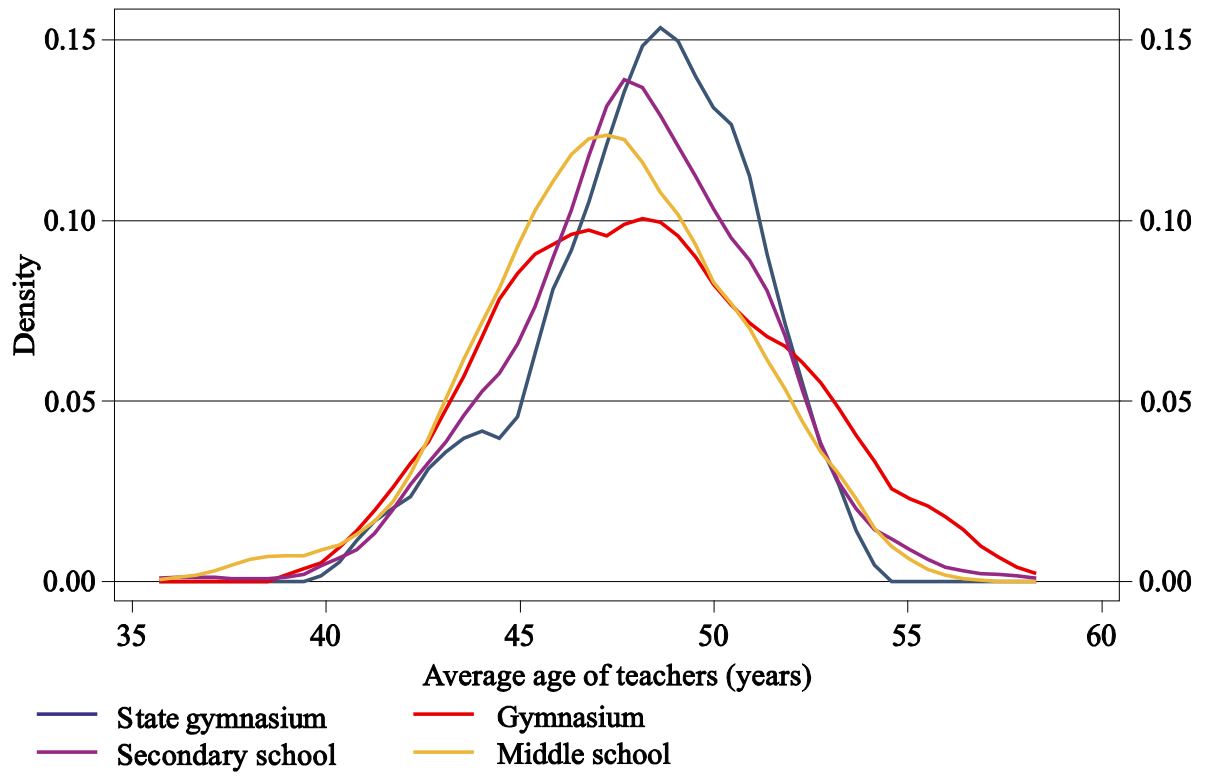

Sources: Ministry of Education and Science data and the author's calculations. 


\section{BIBLIOGRAPHY}

ABRIGO, Michael Ralph M., LAVADO, Rouselle F., BARRIOS, Erniel B., GOZUN, Brian C. (2014). Estimating the Efficiency of Philippine Public High Schools Using Spatio-Temporal Stochastic Frontier Analysis. DLSU Business \& Economics Review, vol. 23, No. 2, pp. 80-87.

AGASISTI, Tommaso (2013). The Efficiency of Italian Secondary Schools and the Potential Role of Competition: A Data Envelopment Analysis Using OECDPISA2006 Data. Education Economics, vol. 21, issue 5, pp. 520-544.

AIGNER, Dennis J., LOVELL, Knox, SCHMIDT, Peter (1977). Formulation and Estimation of Stochastic Frontier Production Function Models. Journal of Econometrics, No 6, 1977, pp. 21-37.

ALEXANDER, W. Robert J., HAUG, Alfred A., JAFORULLAH, Mohammad (2010). A Two-Stage Double-Bootstrap Data Envelopment Analysis of Efficiency Differences of New Zealand Secondary Schools. Journal of Productivity Analysis, vol. 34, issue 2, October 2010, pp. 99-110.

BARBER, Michael, MOURSHED, Mona (2007). How the World's Bbest-Performing School Systems Come out on Top. McKinsey \& Company, September 2007. 56 p.

BARRERA-OSORIO, Felipe, GARCIA-MORENO, Vicente, PATRINOS, Harry Anthony, PORTA, Emilio (2011). Using the Oaxaca-Blinder Decomposition Technique to Analyze Learning Outcomes Changes over Time: An Application to Indonesia's Results in PISA Mathematics. World Bank Policy Research Working Paper, No. 5584, March 2011. 25 p.

BELOTTI, Federico, DAIDONE, Silvio, ILARDI, Giuseppe, ATELLA, Vincenzo (2013). Stochastic Frontier Analysis Using Stata. The Stata Journal, vol. 13, No. 4, pp. 719-758.

BURNEY, Nadeem A., JOHNES, Jill, AL-ENEZI, Mohammed, AL-MUSALLAM, Marwa (2013). The Efficiency of Public Schools: the Case of Kuwait. Education Economics, vol. 21, No. 4, pp. 360-379.

CARTER, Lacy (2012). Data Envelopment Analysis: Measurement of Educational Efficiency in Texas. Dissertation prepared for the Degree of Doctor of Education. University of North Texas, August 2012. 102 p. [viewed 1 September 2017]. Available from: http://digital.library.unt.edu/ark:/67531/metadc149569/m2/1/high_ res_d/dissertation.pdf.

CHINGOS, Matthew M. (2012). The Impact of a Universal Class-Size Reduction Policy: Evidence from Florida's Statewide Mandate. Economics of Education Review, vol. 31, issue 5, October 2012, pp. 543-562.

CHINGOS, Matthew M., PETERSON, Paul E. (2011). It's Easier to Pick a Good Teacher than to Train One: Familiar and New Results on the Correlates of Teacher Effectiveness. Economics of Education Review, vol. 30, issue 3, June 2011, pp. 449465. 
CLOTFELTER, Charles, LADD, Helen F., VIGDOR, Jacob L., WHEELER, Justin (2007). High-Poverty Schools and the Distribution of Teachers and Principals. North Carolina Law Review, vol. 85, pp. 1345-1379.

COELLI, Tim (1996). A Guide to FRONTIER Version 4.1: A Computer Program for Stochastic Frontier Production and Cost Function Estimation. Centre for Efficiency and Productivity Analysis (CEPA) Working Paper, No. 7/96. 33 p.

CRESPO-CEBADA, Eva, PEDRAJA-CHAPARRO, Francisco, SANTÍN, Daniel (2014). Does School Ownership Matter? An Unbiased Efficiency Comparison for Regions of Spain. Journal of Productivity Analysis, vol. 41, issue 1, February 2014, pp. 153-172.

DOLTON, Peter, MARCENARO-GUTIÉRREZ, Oscar D. (2011). If You Pay Peanuts Do You Get Monkeys? A Cross-Country Analysis of Teacher Pay and Pupil Performance. Economic Policy, vol. 26, No. 65, pp. 5-55.

ESCARDÍBUL, Josep-Oriol, CALERO, Jorge (2013). Two Quality Factors in the Education System: Teaching Staff and School Autonomy. The Current State of Research. Regional and Sectoral Economic Studies, vol. 13, issue 3, pp. 5-18.

ESSID, Hédi, OUELLETTE, Pierre, VIGEANT, Stéphane (2013). Small Is Not that Beautiful after All: Measuring the Scale Efficiency of Tunisian High Schools Using a DEA-Bootstrap Method. Applied Economics, vol. 45, issue 9, pp. 1109-1120.

Eurostat database [viewed 4 September 2017]. Available from: http://ec.europa.eu/eurostat/data/database.

HANUSHEK, Eric A. (2011). Valuing Teachers: How Much Is a Good Teacher Worth? Education Next, vol. 11, No. 3, Summer 2011, pp. 40-45.

HANUSHEK, Eric A. (1997). Assessing the Effects of School Resources on Student Performance: An Update. Educational Evaluation and Policy Analysis, vol. 19, issue 2, Summer 1997, pp. 141-164.

HARRIS, Douglas N., SASS, Tim R. (2008). Teacher Training, Teacher Quality and Student Achievement. National Center of Analysis of Longitudinal Data in Education Research. Working Paper, No. 3, March 2008. 63 p.

HAUNER, David, KYOBE, Annette J. (2008). Determinants of Government Efficiency. International Monetary Fund Working Paper, No. 08/228. 27 p.

HIRAO, Yukiko (2012). Efficiency of the Top 50 Business Schools in the United States. Applied Economics Letters, vol. 19, issue 1, pp. 73-78.

HOXBY, Caroline M. (1998). The Effects of Class Size and Composition on Student Achievement: New Evidence from Natural Population Variation. National Bureau of Economic Research Working Paper, No. 6869, December 1998. 61 p.

HUGUENIN, Jean-Marc (2015). Determinants of School Efficiency: The Case of Primary Schools in the State of Geneva, Switzerland. International Journal of Educational Management, vol. 29, issue 5, pp. 539-562. 
KANE, Thomas J., ROCKOFF, Jonach E., STAIGER, Douglas O. (2008). What Does Certification Tell Us about Teacher Effectiveness? Evidence from New York City. Economics of Education Review, vol. 27, issue 6, December 2008, pp. 615-631.

LAIZĀNE, Ināra (2014). Skolēnu mācību sasniegumus ietekmējošie faktori dabaszinībās. [Factors Influencing Pupils' Academic Achievements in Science]. Proceeding of the International Scientific Conference, 23-24 May 2014, University of Rēzekne, vol. 1, pp. 435-447.

Latvijas barometrs (2016). Izglittība [Education]. Results of the public opinion survey conducted in July 2016. Baltic International Bank. 29 p. [viewed 1 September 2017]. Available from: https://www.bib.eu/uploads/2017/02/2016.08.Izglitiba_Baltic_ International_Bank_Latvijas_barometrs.pdf.

LETA Information Agency (2017). Centralizēto eksāmenu vidējo rezultātu salïdzinājums 2015.-2017. (\%) [Comparison of the average results obtained in centralised exams 2015-2017. (\%)]. Published on 29 June 2017 [viewed 1 September 2017]. Available from: $h$ ttps://infogram.com/centralizeto_eksamenu_videjo_rezultatu _salidzinajums_2015_2017_.

LOEB, Susanna, PAGE, Marianne E. (2000). Examining the Link between Teacher Wages and Student Outcomes: The Importance of Alternative Labor Market Opportunities and Non-Pecuniary Variation. Review of Economics and Statistics, vol. 82, issue 3, August 2000, pp. 393-408.

METZLER, Johannes, WÖSSMANN, Ludger (2010). The Impact of Teacher Subject Knowledge on Student Achievement: Evidence from Within-Teacher Within-Student Variation. CESifo Working Paper, No. 3111, June 2010. 39 p.

NEUMARK, David (1988). Employers' Discriminatory Behavior and the Estimation of Wage Discrimination. Journal of Human Resources, vol. 23, issue 3, pp. 279-295.

OAXACA, Ronald L., RANSOM, Michael R. (1994). On Discrimination and the Decomposition of Wage Differentials. Journal of Econometrics, vol. 61, issue 1, March 1994, pp. 5-21 [viewed 4 September 2017]. Available from: https://doi.org/10.1016/0304-4076(94)90074-4.

OECD (2016). Education in Latvia. OECD Library. 19 May 2016 [viewed 1 September 2017]. Available from: http://www.oecdilibrary.org/education/education-in-latvia_9789264250628-en.

PEREIRA, Manuel Coutinho, MOREIRA, Sara (2007). A Stochastic Frontier Analysis of Secondary Education Output in Portugal. March 2007. 34 p. [viewed 1 September 2017]. Available from: http://ssrn.com/abstract $=1398692$.

PURVIN̦Š, Māris (2017). Mācību sasniegumus ietekmējošie faktori Latvijas vispārizglìtojošās skolās [Factors Influencing Education Achievements in Latvian General Schools]. Doctoral dissertation. University of Latvia. 167 p.

RAPOSO, Isabel, MENEZES, Tatiane (2011). Public School Efficiency Using Data Envelopment Analysis: An Empirical Application for Brazil. European Regional Science Association ERSA Conference Papers, No. ersa11p1594, September 2011. 
RIVKIN, Steven G., HANUSHEK, Eric A., KAIN, John F. (2005). Teachers, Schools and Academic Achievements. Econometrica, vol. 73, No. 2, March 2005, pp. 417458.

SCIPPACERCOLA, Sergio, D'AMBRA, Luigi (2014). Estimating the Relative Efficiency of Secondary Schools by Stochastic Frontier Analysis. Procedia Economics and Finance, vol. 17, pp. 79-88.

STAIGER, Douglas O., ROCKOFF, Jonah E. (2010). Searching for Effective Teachers with Imperfect Information. Journal of Economic Perspectives, vol. 24, No. 3, Summer 2010, pp. 97-118.

VILERTS, Kārlis, KRASNOPJOROVS, Oḷegs, BRĒĶIS, Edgars (2015). Does Education Affect Wages during and after Economic Crisis? Evidence from Latvia 2006-2012. Latvijas Banka Working Paper, No. 3/2015. 50 p.

YALÇIN, Seher, TAVŞANCIL, Ezel (2014). The Comparison of Turkish Students' PISA Achievement Levels by Year via Data Envelopment Analysis. Educational Sciences: Theory and Practice, vol. 14, No. 3, pp. 961-968. 